\title{
ON THE GROWTH OF THE BALEEN PLATE OF THE FIN WHALE') AND THE BLUE WHALE') by
}

\author{
W. L. VAN UTRECHT
}

Zoological Laboratory, University of Amsterdam

\section{CONTENTS}

\section{CHAPTER I}

Introduction . . . . . . . . . . . . 3

1. Literature . . . . . . . . . . 3

2. Objections . . . . . . . . . . . 5

a. Records . . . . . . . . . . 5

b. Data about food . . . . . . . . . 5

c. Migration and distribution . . . . . 6

3. Factors which control the growth of cutaneous epithelium . . . . . . . . . . . . 8

4. Conclusions . . . . . . . . . . 9

\section{CHAPTER II}

Histological examination of the "root" of the baleen plate . . . . . . . . . . . . . . . 10

1. Material and method . . . . . . 10

2. Results . . . . . . . . . . . . . 11

A. General description and macroscopical examination of the baleen plate and its "root" 11

B. Histology of the dermis and epidermal tissue of the "root" of the baleen plate . . 14

a. The dermis of the gum . . . . . . 14

b. The dermo-epidermal junction of the gum . . . . . . . . . . . 14 c. The epidermal tissue of the gum . . 15

d. The stratum basale of the gum . . . 15

e. The stratum spinosum of the gum . . 16

C. Histology of the dermis and epidermal tissue covering the corium wall, and the cortex of the baleen plate . . . . . . . . 19

a. The stratum basale of the epithelium covering the corium wall . . . . . 21

b. The stratum spinosum of the epithelium covering the corium wall . . . . 21

c. The cortex in the "root" of the baleen plate . . . . . . . . . . . 23

D. Formation of tonofibrils . . . . . . 24

E. Examination of the "root" of the baleen plate in polarized light . . . . . 26

\section{CHAPTER III}

1. Conclusions . . . . . . . . . . . . 27

2. Summary . . . . . . . . . . . 32 Samenvatting . . . . . . . . . . . 33

3. Acknowledgements . . . . . . . . . 34

4. References . . . . . . . . . . . . 34

\section{CHAPTER I}

\section{INTRODUCTION}

\section{Literature}

The determination of the age of individuals of the different species of Whales, that enter the commercial catches, is very important. For, changes in the age composition of the catch of a certain species may give an indication about the state of the stock of that species.

Already Sconesby (1820) pointed to a possible correspondence of the ridges that are visible on the surface of the baleen plates of Mystacoceti, with the rings on the horns of cattle and the rings in the wood of trees.

1) Balaenoptera physalus (Linnaeus, 1758)
In his studies about Whales Hunter (1787) gave a short description of the baleen plate including the part in the gum. In a drawing he gives structures that are visible in a longitudinal section through two adjacent baleen plates and the gum in between. This is a sagittal section, parallel to the longitudinal axis of the plates and perpendicular to their surface. In the "intermediate substance" (i.e. the gum), between the two plates, laminae are present, which in his opinion form the "substance" of the plate, by which he means the outer layers of the baleen plate. These laminae run through the "intermediate substance" from one baleen plate to the next without interruption. Each plate is hollow, filled with a

2) Balaenoptera musculus (Linnaeus, 1758) 
thin broad and vascular processus (i.e. a mass of connective tissue). Hunter distinguishes three "stages" in the growth of the baleen plate. In his opinion the first part of the growth of the baleen plate takes place on the inside of the hollow. In the second part of the growth additional layers are added to the outside of the part first formed. These layers are added by the tissue which also forms the semihorny substance between the two baleen plates. The three parts of the baleen plate formed during its growth are, in HUNTER's opinion, the part formed on the broad vascular processus on which the "hairs" of the baleen plate are found, the part formed on the outside of the plate (the outer layers of the plate) and the part formed by the "intermediate substance".

HunTer is very definite when he says that a part of the outer layers of the whalebone is formed by the substance between two baleen plates.

Eschricht and Reinhardt $(1861,1866)$ and TullBERG (1883) examined the baleen plates and their parts in the gum, of the Greenland Right Whale and the Blue Whale. Eschricht and Reinhardt found the same structures in the "roots" of the baleen plates as described by Hunter. They arrived at the conclusion, however, that the baleen plate, in particular the outer layers of it, does not consist of material formed by the tissue in between the two plates (gum or "intermediate substance") but entirely of material formed by the epithelium that covers the wall of connective tissue in the "root" of the plate. This means that in their opinion the growth of the baleen plate in length and also in thickness is solely caused by addition of material from the inside to the inner side of the outer covering layers of the plate. Tullberg (1883) has studied the development of the baleen plate in foetuses. He has not given any new evidence concerning the growth of the plate, but supports the views of EscHRICHT and REINHARDT (1861, 1866). RuUd (1940, 1945, Ruvd et al., 1950) has adopted the opinion of Eschricht and ReINHARDT that the growth of the baleen plate is caused by addition of material from the epithelium that covers the corium wall in the "root" of the baleen plate to the inner side of the outer layers of the plate.

Ruud (1940) and Tominin (1945) have developed an apparatus by means of which it is possible to make records of the thickness along the whole length of the free part of the baleen plate which hangs down from the roof of the mouth in Baleen Whales. In his fig. I Ruov (1940) gives an actual record of the thickness of a baleen plate together with the plate. It is evident that the different ridges

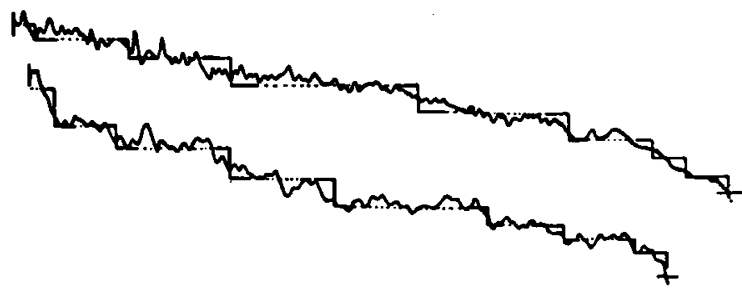

Fig. 1. Record of the thickness of a baleen plate, devided into "growth periods". (after RUUD, 1945)

in the plate correspond with the different peaks in the record. The free end of the baleen plate which is formed at a younger age than the parts of the plate closer to the gum is thinnest. This is shown in the right part of the curve. In a number of spots in the records certain "jumps" are present, which in Ruud's opinion indicate the moments when the thickness of the baleen plate suddenly increases. In the analyses of the records of baleen plates RuUd $(1940,1945)$ considers the "jumps" very important, because they indicate the beginning of a feeding period after a period of migration. From the actual record (fig. 1, RuUn, 1940) it appears that there is a gradual increase in thickness of the baleen plate. This increase, however, is exaggerated because the exposed part of the baleen plate is subject to wear. Superimposed on this increase are the peaks and "jumps". In fig. 2 a schematic curve of the thickness is given. The points $A, B, C$ and $D$ are the "jumps", the parts A-B, B-C and C-D are "the growth periods" (Ruvd, 1940, 1945) of the baleen plate.

If the ideas of Eschricht and Reinhardt (1861, 1866) and Ruud (1940, 1945) about the growth of the baleen plate are correct, the addition of layers of material to the outer covering layer (cortex; see page 12) of the plate could only cause "jumps" on

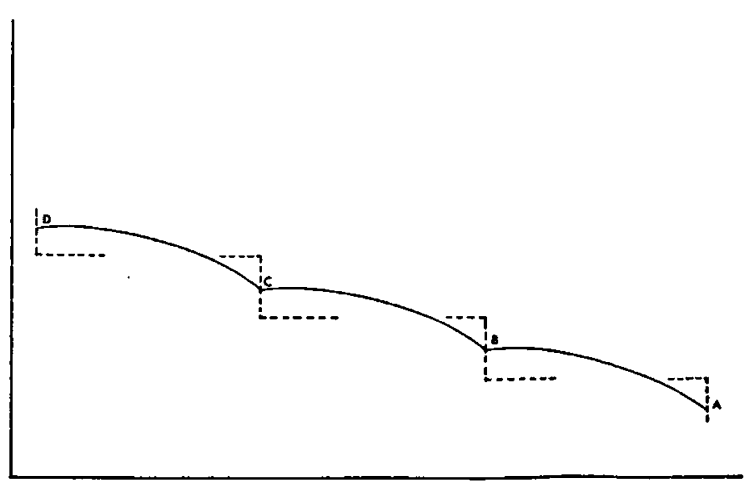

Fig. 2. Scheme of a record of the thickness of a baleen plate. The points $A, B$ and $C$ are the "jumps". The parts $A-B, B-C$ and $C-D$ are the "growth periods". 
the inner side of the outer covering. It would be difficult to account for the "jumps", actually visible on the outer surface of the baleen plate, and in the records. If the addition of material only takes place along the inner side of the outer covering of the baleen plate, only a smooth surface of the outer covering is to be expected, as it may be supposed that successive layers will overlap each other.

\section{Objections}

\section{a. Records}

When a great number of records of baleen plates is compared individual differences are obvious. The records of baleen plates of male and female animals of the same species show even greater differences. This is also the case when records of baleen plates of animals of different species of Rorquals are compared. As was pointed out above, a general increase in thickness interrupted by sudden "jumps" is shown in the record of a baleen plate. Besides these "jumps" there are peaks and hollows superimposed on the general increase. In a careful examination and comparison of a great number of baleen records a regularity in this system of peaks and hollows becomes evident. On the other hand it also becomes evident that the "jumps" are not regular. Also the distance between the different "jumps" varies (see fig. 1) (see also van Utrecht-Cock, 1965). This is contrary to what might be expected if migratory movements and changes from a non-feeding season to a feeding season are regular (see RuvD, 1940, 1945; Mackintosh and WheEler, 1929; MackiNTOSH, 1942). Moreover, recent data about migration, food, etc. have made the interpretation of the "jumps" questionable.

\section{b. Data about food}

MAckintosh (1942) is of the opinion that Blue Whales and Fin Whales do not feed during the time when they are in tropical waters, but he also pointed to the fact that the stomachs incidentally contain some food. The idea that the animals do not take food or only small quantities during the time when they are in tropical and sub-tropical waters, is mainly based on the fact that the amount of oil produced from animals caught in early summer is small. They have just arrived in high latitudes then.

But the amount of oil gradually increases during the whaling season. The same holds good for the thickness of the layer of blubber (Mackintosh and Wheeler, 1929; Mackintosh, 1942; Slijper, 1948, 1954).
According to Dawbin (1960) Humpback Whales do sometimes feed during their migration through the New Zealand waters if food is available there. Chittlebonougr (1958) on the other hand never found any food in the stomachs of Humpback Whales caught in the Australian waters. The contents of the stomachs of Whales caught in the North Pacific consist more often of fish, in the stomachs of Whales from sub-tropical waters more Crustacea are found (Nемото, 1959). The food of the Whales caught in the Antarctic waters consists mainly of Euphausiacea. Data about the feeding conditions and stomach contents of Whales caught in sub-tropical and tropical waters are very scanty. Most of the data that are available have been collected by studying the Humpback Whale.

Dawbiv (1956) mentions the fact that the stomach contents of a number of Humpback Whales caught in the New Zealand waters consisted of the Euphausid, Nyctiphanes australis. The catch of the land station at Durban, South Africa, consists mainly of Fin Whales. These animals are caught in subtropical waters during the period when they migrate along the east coast of South Africa in northern as well as in southern direction. Most of the time the catchers of this land station have to go a considerable distance from the coast before they encounter Whales. Due to the insulating qualities of the layer of blubber under the skin and the fact that there is no transport of warmth by means of the blood through the blubber to the surface of the body, the temperature of a dead whale rises considerably. One may expect the stomach contents of these animals to decompose in rather a short time after death so that only a semi-fluid mass will be found.

On the other hand one may also expect the animals take only a little or no food at all during migration. In tropical waters no pelagic whaling of Baleen Whales is practised. Baleen whaling can only be practised from land stations situated along the migration routes. Consequently no data are available concerning the stomach contents of Whales from areas where they are present for some time. Therefore comparison with data concerning animals from the Antarctic waters is impossible. So conclusions about feeding habits and feeding conditions of the Fin Whales from tropical and sub-tropical seas are only based on a few facts, while most is speculation. It is evident that the change from a nonfeeding period to a feeding period as a cause of the formation of a "jump", is an uncertain factor. Because nearly no exact data are known about food consumption in sea areas, where the Whales are in 
lower latitudes in winter, the "jumps" are inconclusive in the division of the records into growth periods. In recent years BaKer (1964) found Euphausids present in the stomachs of Fin Whales, in particular in young animals, he examined at the Durban land station. The animals concerned were caught in the sub-tropical region on their migration route.

\section{c. Migration and distribution}

More data are known about the second point in Rưn's $(1940,1945)$ arguments in the analyses of the baleen records, i.e. the migration and distribution. By means of direct observations and whale marking Dawbin (1956) showed that the Humpback Whale migrates along the coasts of New Zealand, as well on their northward migration as on their southward migration. The same holds good for their movements in the breeding area in the Australian waters (Chittleborough, 1953). During the other periods of migration on the southern hemisphere in summer the Humpback Whales are no longer dependent on the coasts.

By means of whale marking some positive results, though on a much smaller scale, are obtained for the migration of the Blue Whale and the Fin Whale in other areas. As most of this marking is done in the Antarctic waters and as the greater part of the marks which are found back are from animals caught in the same waters, these data are of limited value (Brown, 1954, 1956, 1957, 1958, 1959, 1960, 1961, 1962). Observations of Whales from merchant vessels confirm the existence of migratory movements, (SLIJPer and van Utrecht, 1959; Slijper, van Utrecht and NAAKTGEBOREN, 1964). It is commonly accepted that the Blue Whale, the Fin Whale and the Humpback Whale and also other species of Baleen Whales migrate to high latitudes in spring and to lower latitudes in autumn. As to the Humpback Whale, DAwBIN (1956) arrives at the conclusion that the direction of the migration in the New Zealand waters is not strongly influenced by currents, depth, or distance to the coast. Of course the coastline determines the direction in which the Humpback Whales travel. There are, however, indications that point to incidental influences as, for instance, tidal streams, turbidity and presence of food. As no whaling is practised in the seas north of Australia it is still an open question whether some of the Humpback Whales go farther north than the Australian east coast or whether a part of this group penetrates into the Indonesian Archipelago or go even farther north.
By means of whale marking and analysis of bloodtypes NishiwaKr (1960) found that the stock of Humpback Whales in the North Pacific is composed of different groups, which show irregularities in their migrations. For other sea areas no such detailed data are available concerning the migratory movements of this species. It is generally. accepted that the total population of this species makes regular migrations, but in the light of what was found for whales in the North Pacific, this is open to doubt.

The same holds good for the marking of Fin Whales and Blue Whales in tropical and sub-tropical waters. Only a very small number of them has been marked in these waters but a considerable number was marked in the Antarctic. About 5\% of these marks were recovered (ClARKE, 1957).

The numbers marked in tropical and sub-tropical waters are so small that this cannot lend much support to a theory on the migration movements of this species. Up to this moment eleven marks have been recovered from Fin Whales, which confirm the migration between the Antarctic and warmer waters, both in northerly and in southerly direction (ARseniev, Brown, Chittleborough and Omura, 1962).

For land stations and also in pelagic whaling the changes in numbers of animals and the changes in fatness in the course of the "season" in a certain area are indications for the migratory movements of the Fin Whale. The numbers of animals involved in these migrations are unknown. Consequently there is no certainly about the numbers of animals which stay in low or high latitudes in summer and winter respectively.

Other indications of possible migratory movements are the development of the film of diatoms on the skin of Whales during the time they stay in the Antarctic waters, presence of parasites on the skin and the presence of open wounds and scars (MACKINTOSH and Wheeler, 1929; Hart, 1935; Pike, 1951, 1953; Nemoto, 1955; van Utrecht, 1959).

Most Fin Whales are caught in the Antarctic waters in a limited period of time. No whaling is practised in high latitudes in winter and whaling in low latitudes is only practised on a small scale. Therefore it is impossible to get a better insight in the movements and distribution of these animals. Consequently the observation of whales from ships is very important in order to get an insight in this problem, in particular concerning the Fin Whale. The merchant service covers all sea areas between $60^{\circ} \mathrm{N}$ and $40^{\circ} \mathrm{S}$ in all months. Therefore its observations are an important source of information, used by the "National Institute of Oceanography", Great Britain. In 1952 this in- 
stitute set up a program to collect data about the Whales observed by rather a small number of "selected ships" (Mackrntosh, 1952). A similar program was set up in 1954 by the "Netherlands Whale Research Group" in which all ships of the Netherlands Royal Navy and the Dutch Merchant Service participated (SlIJPER, 1954). From data obtained in this way it appeared that only few or no "Rorquals" (in these researches "Rorquals" comprise Blue, Fin, Sei and Bryde Whales) are present in the central sea areas of the northern and southern part of the Atlantic Ocean and in the central area of the Indian Ocean. These areas are known to be poor in biological productivity (WALFoRd, 1958; MARR, 1956, 1957) so that it is reasonable to assume that only a very small number of "Rorquals" is present in those areas. During the summer months most "Rorquals" are sighted in higher latitudes. Slijper, van Utrecht and NaAKTGEBOREN (1964), however, pointed to the possibility that a certain number of animals stay during the summer in low (even tropical) latitudes. In winter only few animals are present north of $60^{\circ} \mathrm{N}$ and south of $40^{\circ} \mathrm{S}$ (Brown, 1958; SLIJPER, van UTREChT and NaAktgeboren, 1964; Mackintosh, 1942). The northern and southern border of the area visited by "Rorquals" is determined by the border of the packice, in the Arctic as well as in the Antarctic Ocean (Brown, 1958; Slijper, van Utrecht and NaAkTGE.BoneN, 1964). From observations on board the f.f. "Willem Barendsz", early in the Antarctic "season" in the first half of December, it appeared that Fin Whales are present near the pack-ice already early in the "season" or that they have been there during the whole winter season. For, these animals are very fat, the film of diatoms is highly developed, and no open or healing wounds are present in the skin. Also small foetuses are found in these animals in this period, the smallest being $9 \mathrm{~mm}$.

From all observations it is obvious that "Rorquals" are present in lower latitudes and also in high latitudes during all months of the year. Moreover there are movements to higher and lower latitudes in spring and autumn respectively, in the Atlantic as well as in the Indian Ocean. They are always in those areas in lower latitudes which are rich in food (SLIjPER, VAN UTRECHT and NAAKTGEBOREN, 1964).

It is unknown whether or not "Rorquals" use these sources of food, but it is reasonable to suppose that they do. At least this possibility must not be neglected, as these animals inhabit these regions regularly for a shorter or longer time. Ruud $(1940,1945)$ neglects this possibility. In his opinion the "Rorquals" and particularly the Fin Whales, have a re- gular cyclus of a feeding season in high latitudes and a non-feeding season, which is at the same time the breeding season, in lower latitudes.

Summarizing from what is said above it is evident that migrations are not as regular as was formerly accepted. On the other hand it is quite reasonable to assume that "Rorquals" e.g. the Fin Whales will take the food available when they are in higher latitudes. It is also reasonable to assume that the animals which stay in tropical or sub-tropical waters in summer will do the same. Then one may expect the "jumps" not always to be present in the records of the baleen plates or one may expect them to be at irregular distances from each other. "Jumps" are not always present in the figures given by Ruov $(1940,1945)$ and in our own records in a considerable number of cases. If they are present the distance between them varies to a considerable extent. Occasionally the distance between two "jumps" in one part of the record is nearly twice as long as it is in other parts. It is quite reasonable to assume that these irregularities in the records of the baleen plates are connected with irregularities in the migratory movements of the "Rorquals" and with the possibility that these animals take food during the shorter or longer time they are in tropical or subtropical regions. The variation in length of the "growth periods", the variation in number of "jumps" and the presence or absence of the "jumps" in parts of the records of the thickness of the baleen plates can be explained by means of irregularities in the migratory movements of the Fin Whale. This is confirmed by the results of observations of whales in tropical and sub-tropical regions (SLIJPER, vaN UTRECHT and NAAKTGEBOREN, 1964).

It is evident from the above mentioned facts that the hypothesis used by Ruov $(1940,1945,1958)$ is not altogether acceptable as the only criterion in the analysis and division into "growth periods" of the records of baleen plates, as a means of determining the age of the Fin Whale. Other criteria and phenomena in these records must also be taken into account in order to give a firm basis to the method of age determination, and to get the "growth periods" based on the regular variations in the growth of the baleen plate.

One of the most striking points in the records of baleen plates is the system of peaks and hollows superimposed on the general trend of increasing thickness. Ruov (1940, 1945) does not use this system in the division into "growth periods" of the record. He only uses the "jumps". From the examination of a great number of records of baleen plates 
of Fin Whales, these systems proved to be different in both sexes (van UTRECHT-Cock, 1965).

It is evident that these peaks and hollows are caused by a sudden increase or decrease of the growth of the baleen plate. It is reasonable to assume that they are caused by changes in the physiological balance of the animals, for instance by the sexual cycle, and also by changes in environment. As there are differences in the records of the baleen plates of the male and female Fin Whales, it is obvious that the sexual cycle has great influence on the growth of the plate. The supposed influence of the sexual cycle on the growth of the baleen plates plays an important role in the analyses of the records of the plates. The advantage is that the "growth periods" are regular in length. This regularity could not be obtained by Ruud. An extensive description of this method and of the results obtained in this way is given by VAN UTRECHT-CocK (1965).

Factors which are supposed to influence the growth of the baleen plate are migration, environment, distribution, food and the sexual cycle. A number of factors are linked with each other as, for instance, food and daylight; the development of the planktonic organisms starts in spring when the daily quantity of light increases. On the other hand for the Fin Whales the length of the day depends on where they are. When they are migrating to the south in the Southern Hemisphere in spring, they will experience a gradual increase in the length of the day. The same holds good when they move to the north to a lower latitude in autumn. In this way migration, food and length of the day are connected.

LAws (1961) is of the opinion that the sexual cycle in the female Fin Whales is connected with the length of the daylight. The ovulatory cycle would start when the length of the day increases. The Whales will certainly experience an increase in the length of the day two times a year, in spring when they migrate to a high latitude, and in autumn when they go to a low latitude. In this way one gets a reasonable explanation for the theory that the two ovulatory cycles are connected with an increase in the length of the day. It was found that the interval between successive ovulations in a number of cases was four months (van UTRECHT-Cock, 1965). This points to the possibility that these animals lived under favourable conditions for a longer period and probably did not migrate (Slujper, van UTRECHT and NAAKTGEBOREN, 1964; see also van UtRECht-Cock, 1965, page 67).

\section{Factors which control the growth of cutaneous epithelium}

As the baleen plate is a derivative of the cutaneous epithelium that covers the roof of the mouth it is important to know more about the factors that influence the growth of this epithelium. Growth of the epidermis and also of its derivatives is caused by the division of the cells in the basal layers of this epithelium. If there is a rhythm in the mitotic activity of animal cells, it is diurnal in most cases. Under normal conditions of light a 24-hours cycle exists with a maximum number of cell divisions during the period from about 8 p.m. till midnight. The minimum number of cell divisions is found at about noon. Continuous light disturbs the rhythm. Continuous darkness, however, does not influence the mitotic rhythm. Twelve hours of artificial light causes irregularities in the mitotic activity (CARLETON, 1934). The daily rhythm of the mitotic activity in the skin of the mouse was examined by CoOper and Franklin (1940). Contrary to what was found for the skin of man with its maximum number of mitosis at about 10 p.m., the maximum of mitotic activity in the skin of the mouse was found to be at about 10 a.m.. Cooper and Franklin attribute this to the fact the mouse is a nocturnal animal. These animals have their period of rest and of tissue repair during the daytime. According to this conclusion the high mitotic activity during the period of rest is connected with other physiological phenomena, that occur during this period. Bullougr (1949) found a reduced mitotic activity in the epidermis of the mouse as a result of a restricted diet.

In the vaginal epithelium and epidermis of the mouse, cyclical changes occur in the mitotic activity. Consequently there are also changes in the thickness of the epithelia, which are correlated with the oestrus cycle in these animals (Bullough, 1943, 1946). Mitotic activity in both tissues is maximum during pre-oestrus. This does not hold good for all tissues. Apparently the mitotic activity largely depends on the need for replacement of cells (Bullougr, 1946). It is supposed that the ultimate activity is determined by two opposite factors. One factor, the oestrogens, stimulates the mitotic activity in the tissues, whereas the second factor is a "mitosis depressor", of which Bullougr supposes that it exists in the tissue itself. The latter counteracts the action of the "mitosis stimulator". There is also a third factor, the "wound hormone". This factor is supposed to weaken the "mitosis depressor" and in this way strongly increases the mitosis stimulating action 
of the oestrogeins. Bullough (1962) gives a review of the work on this subject. Glucocorticoids, adrenalin and noradrenalin are shown to have a "mitosis depressing" activity. The oestrogens and androgens, on the other hand, stimulate the mitosis, in particular in certain target-organs, e.g. sexual tissues and skin. They have a weak effect on other tissues. It is shown that especially the skin is sensitive to sex hormones in a number of species of animals. Contradictory results were found by EBLing (1953) and Carter (1953), for instance. In most cases these results are due to the application of unphysiological high doses of the "mitosis stimulator". Such a high dose of each stimulator acts as an inhibitor (or poison). Adrenalin is known to be one of the substances with the strongest inhibitory influence on mitosis. Much adrenalin is formed in periods of stress with its consequent influence on the mitotic activity of the cells. The longer this situation of stress is maintained the higher the number of cells is that undergo mitosis when this inhibition is removed. It is supposed that there is a correlation between the diurnal mitotic activity and stress and consequently the production of adrenalin. The production of adrenalin reaches a high level during the active period and in a "stress situation", and is lowest during the period of rest. Bullougr (1962) assumes, that adrenalin prevents mitosis of the cells of an animal in its active period but does not prevent preparations for mitosis. The longer such a period lasts, the greater the number of cells is which is ready for mitosis when the inhibitor is removed. The rate of mitotic activity cannot be brought to a higher level by application of a greater dose of oestrogens or androgens. These substances then act as "mitosis inhibitors". Consequently it is obvious that the sexual cycle influences the mitotic activity of e.g. the epidermis which is particularly sensitive to the action of oestrogens (Loeb and Haven, 1929; MCCreight and ANDREw, 1956, quoted from Bullough, 1962).

The growth and in particular the formation of rings on the horns of domestic cattle is connected with the sexual cycle. In most races of cattle the first calf is born in the second or third year of life. Consequently one ring on the base of the horn corresponds to an age of two or three years. The second ring is formed during the gestation or birth of the second calf, etc. On the other hand, rings which are less pronounced are formed under the influence of or are the result of changes in the composition of the food or are due to illness (HABERMEHL, 1961). In domestic cattle it is known when changes in com- position and quantity of food occurred and when the animals were ill. Therefore these influences can be taken into account. This is not the case for free living animals. In domestic cattle the influence of gestation, birth and lactation on the growth of the horns can be traced back with great certainty. These data about cattle are important. As in most cases the whole course of life of the animals is known, these data can lend much support to comparable data of free living animals. There is more uncertainty about the life cycle of free living animals, for instance the Chamois. However, the rings on the horns are used for age determination, in which the distance between two rings is supposed to cover a "growth period" of one year (Couturier, 1938; FUSCHLbERGER, 1955).

Fambach (1898) distinguished two types of rings on horns of the Bovidae. In his opinion one type is a constant embellishment of the horns, caused by "periodische Lage-Gestaltsveränderungen der Matrix und seine Papillen oder durch Faltenbildungen der Matrix am Horngrunde". The second type of rings on the horns should appear accidentally: "die zufällig auftretende Ringbildung ist die Folge von entfernt wirkende Ursachen (Trächtigkeit, Futter und Haarwechsel)".

\section{Conclusions}

In conclusion it is obvious that the sexual cycle plays an important role in the growth of the epithelium and consequently in the formation of the differences in thickness of the baleen plates.

As was said before, the records of the thickness of baleen plates of Fin Whales show a system of peaks and hollows. This is different for males and females of the same species. This system has no connection with the "jumps" Ruon (1940, 1945) uses in order to divide the records into "growth periods". It can be supposed that in the baleen plate the increment in length as well as the increment in thickness and the changes in the rate of this increment are influenced by sex hormones, analogous to the variations in the rate of growth of the mammalian epidermis (Bullovgr, 1962). So it may be supposed that in Whales certain peaks in the records of baleen plates are linked with the sexual cycle, as is the case for certain rings on the horns of cattle. The sexual cycles of the male and female Fin Whale are very different. In the records of the baleen plates the different sexes can indeed be recognized by the form of the system of peaks and hollows. In the records of the baleen plates of the females some peaks are 
recognizable as so-called "ovulation peaks" (vaN UTRECHT-Cock, 1965).

These facts strongly suggest that the sexual cycle, besides other factors, influences the growth of the baleen plate in the Fin Whale. If the thickenings of the plate are formed rather quickly, e.g. during an ovulation, which takes place in rather a short period, it is possible to use this system of peaks and hollows to divide the records of the baleen plates into "growth periods", in connection to the sexual cycle. This thickening is, of course, only possible in the part of the baleen plate embedded in the gum. If this addition of material to the part of the plate in the gum, would be along the whole length of that part, it would only mean that the thickness of the plate had gradually increased. However, this does not occur. As the peaks are narrow and are also visible as narrow bands on the surface of the baleen plate it can only mean that these peaks are formed in a restricted area, and in a restricted period of time.

The conclusion is that this method of determining the age can be used if in the growth of the baleen plate these thickenings are formed quickly, and if their formation is limited to a small area. The aim of the present research is to get a better insight into the growth and formation of the baleen plate in the Fin Whale and the Blue Whale and to prove that these thickenings are formed quickly and in a restricted area. This is only possible by means of anatomical, histological and cytological examinations.

\section{CHA P T ER II}

\section{HISTOLOGICAL EXAMINATION OF THE "ROOT" OF THE BALEEN PLATE}

\section{Material and method}

The material used in this research consists of the part of the baleen plate which is embedded in the gum. This is the "root" of the plate. The material was taken from the Fin Whale and the Blue Whale, from females as well as from males, which were all sexually mature.

The material was collected during a number of "seasons" of pelagic whaling in the Antarctic waters, on board the former factory ship "Willem Barendsz" of the Netherlands Whaling Company Ltd. The "roots" of the baleen plates were collected in combination with the baleen plates. In the case of females the ovaries were also collected. All this material was used in the age determination. The longest baleen plate of the whole set of an animal was taken to make a record of its thickness. The two adjacent plates were cut off, and the piece of the gum, with the "roots" in it, was cut out of the whole set (fig. 3). These pieces were stored for about 6 months at $-27^{\circ} \mathrm{C}$. Afterwards they were cut into strips, thawed and fixed in formalin 5\%. For technical reasons it was impossible to fix this material immediately after collection, on board the factory ship.

From each piece of gum two strips, adjacent to each other, were taken. One was used for anatomical and macroscopical examinations, while the other strip was cut into small pieces which were stored in spiritus saponatus for about 6 months in order to soften them. Also diaphanol (Romeis, 1948, par.
2300) was used, but as this affects the structures of the tissue seriously, this method was not further applied. In accordance with the normal procedure, the pieces were dehydrated, embedded in paraffin wax and sections were made of the thickness of $3 \mu$ and $5 \mu$ respectively.

The staining techniques applied were: Azan,

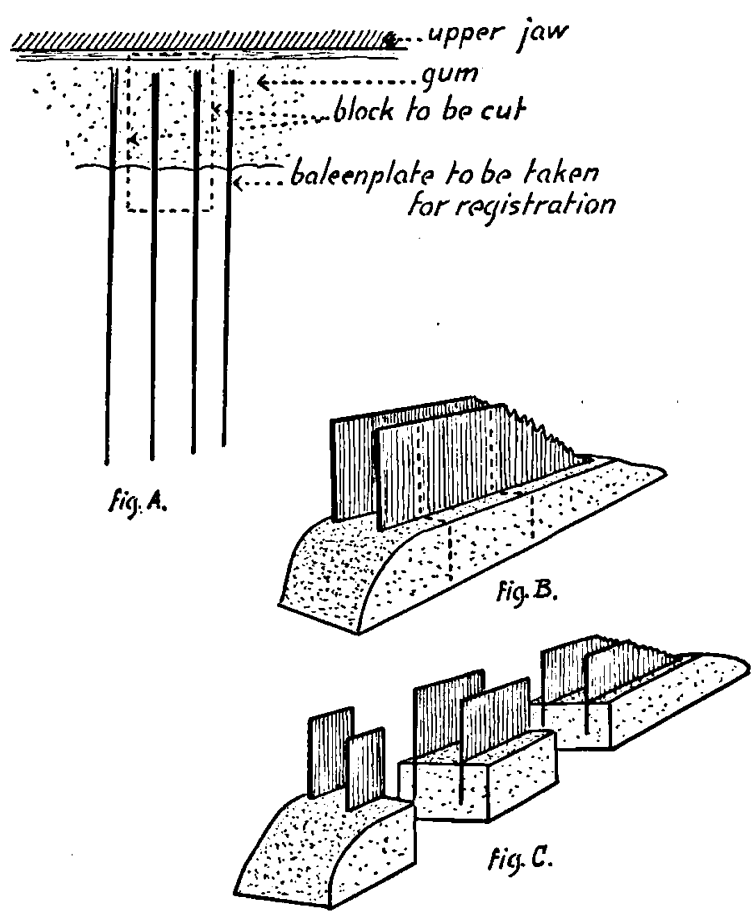

Fig. 3. The way in which the "root" of a baleen plate is cut out of a series of baleen plates (further explanation see text). 


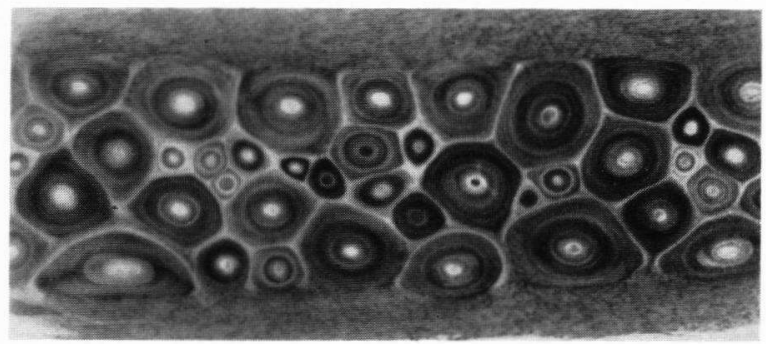

Fig. 4. Transversal section through a baleen plate. 10x.

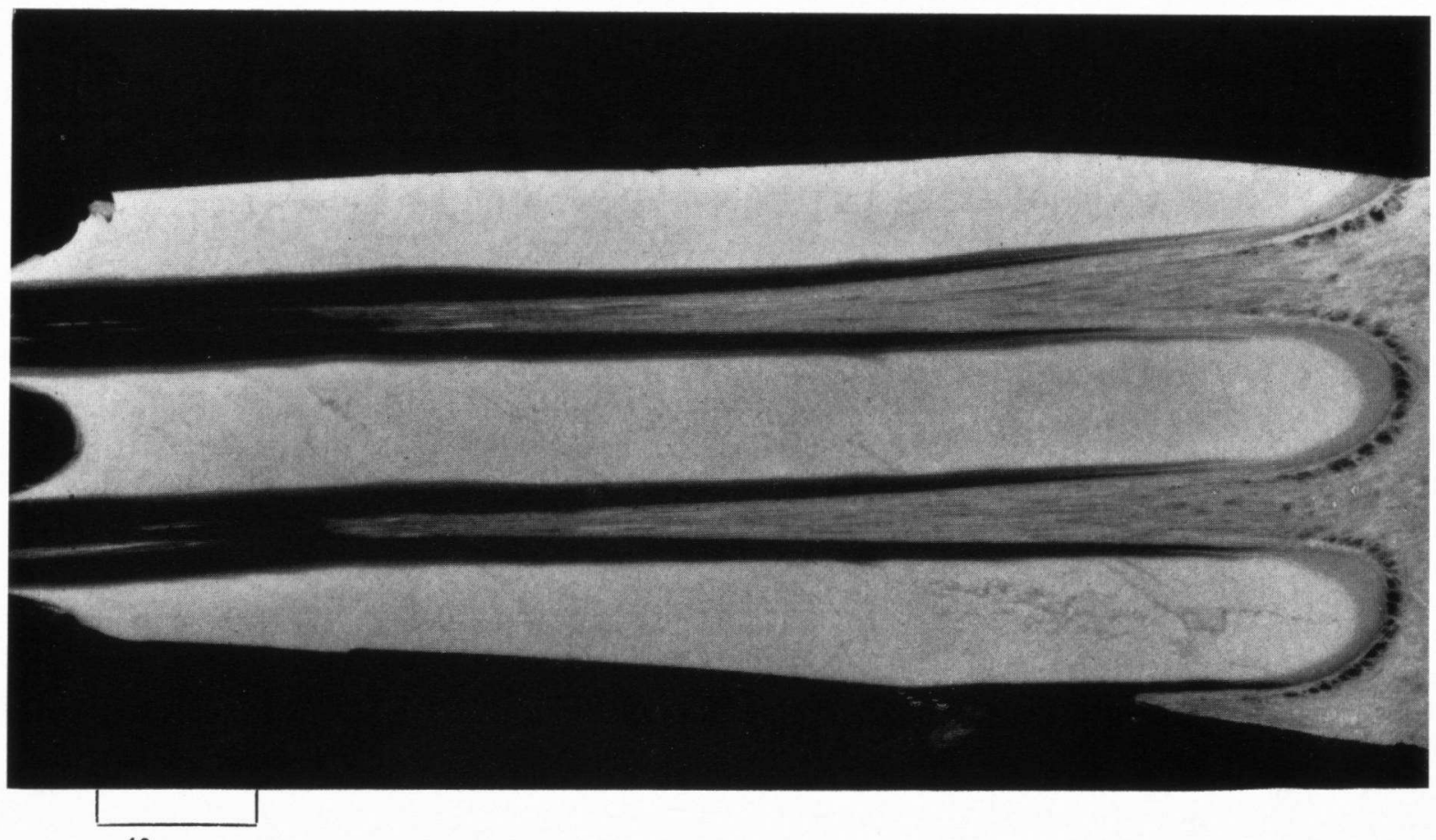

$10 \mathrm{~m} . \mathrm{m}$.

Fig. 5. "Root" of a baleen plate in a section parallel to the longitudinal axis of the plate and perpendicular to its surface. 
Crossmon, Mallory, Haemalum-eosin, iron haematoxilin and silver staining after Gomöri (Romers, 1948). The sections were examined with the ordinary light microscope and also with the phase contrast microscope and in polarized light.

\section{Results}

A. GENERAL DESCRIPTION AND MACROSCOPICAL EXAMINATION OF THE BALEEN PLATE AND ITS "ROOT"

The baleen plates of the Fin Whale and of all other Mysticeti are embedded in the cutaneous epithelium of the upper jaw. This part of the plate will be called the "root" of the baleen plate, the cutaneous epithelium covering the upper jaw, in which the "roots" of the baleen plates are embedded, the "gum". The free end of the baleen plate hangs in the cavity of the mouth where the tips of the plates are situated between the tongue and the lip of the lower jaw, when the mouth is closed. The baleen plates form a series of horny plates with their smooth edges directed laterally and their broad sides facing each other. The inner edge of the baleen plate is the hairy fringe. On both sides of the mouth the whole series of baleen plates is at its base surrounded by a rather high wall, formed by the epithelium. On the lateral sides this wall gradually passes into the lip of the upper jaw. The rows of baleen plates on both sides of the cavity of the mouth are more or less parallel to the longitudinal axis of the head. The separate plates form an angle with the axis in such a way, the outer edge of the plates is placed a little more caudal than the edge directed to the cavity of the mouth. The baleen plates are not straight at their base. They are slightly bent, S-shaped. The plates are circ. $1 / 2 \mathrm{~cm}$ thick in the thickest part and become gradually thinner to both edges. The distance between the plates at the gum is circ. $1 \mathrm{~cm}$. The "hairs" on the inner edge of the baleen plates form a felt-like mat which covers the whole inner "surface" of the row of plates.

From both a transversal section (fig. 4) and a longitudinal section it becomes clear that the baleen plate consists of three layers. The central layer is formed by a mass of horny tubes. These form the medullary layer of the baleen plate. On both sides this layer is enclosed by a compact cortical layer. The horny tubes are not parallel to each other, but all converge in the tip of the foetal baleen plate ("zero point", Ruud, 1945). They all have a lumen, which in a transversal section shows a more or less constant diameter. On the other hand the thickness of the walls of the different tubes varies greatly. This is due to the different numbers of concentric layers of cornified material, of which the walls are composed. The horny tubes with the greatest diameter are situated immediately under the cortical layer of the baleen plate, as is also described by Ruov (1940). Consequently these tubes are not circular but are more or less triangular, the base of the triangle bordering the inner side of the cortex of the baleen plate. In a longitudinal section, parallel to the longitudinal axis of the horny tubes, the layers of the walls of the horny tubes are recognizable. They are rather pigmented. In the lumen of a number of tubes a mass of orange coloured material is found over a certain distance. Probably this is a mass consisting of blood and remnants of cells (TuLlberg, 1883).

The space between the tubes is filled with less pigmented cornified material, which cements the tubes to each other and to the cortex of the baleen plate.

In a transversal section of the "root" of the plate the proportions of the different components vary with the distance of the plane of the section to the surface of the gum. This is also very clearly demonstrated in a section parallel to the longitudinal axis of the "root"-part of the plate, perpendicular to its surface (fig. 5). The length of the part of the baleen plate embedded in the gum varies from 8 to $20 \mathrm{~cm}$. In the longitudinal section of a circ. $12 \mathrm{~cm}$ long "root" of a baleen plate the horny tubes are visible up to a distance of circ. $3-5 \mathrm{~cm}$ from the point where the plate breaks through the surface of the gum. Deeper in the "root" of the plate above this point follows a gradually widening wedge of connective tissue of circ. $7 \mathrm{~cm}$ in length. As soon as the horny tubes can be recognized they are enclosed by the cortical layers on both sides of the plate. Then follows the light grey tissue of the gum. The dark grey cortical layer of the "root" of the baleen plate penetrates very deep into the gum, along the wedge shaped mass of connective tissue. The thickness of this cortical layer gradually diminishes in this direction. At the same time the thickness of the epithelium, situated between the cortex and the wedge of connective tissue, increases. See also the scheme fig. 6.

The terms used by Ruov (1940, 1945), for the different components of the baleen plate and its "roots" are questionable. The wedge-shaped wall of connective tissue, covered with epithelium, is called "pulpa" by Ruov. He also uses the term "enamel" to indicate the outer covering layers of the baleen plate. The layer of horny tubes in between both 


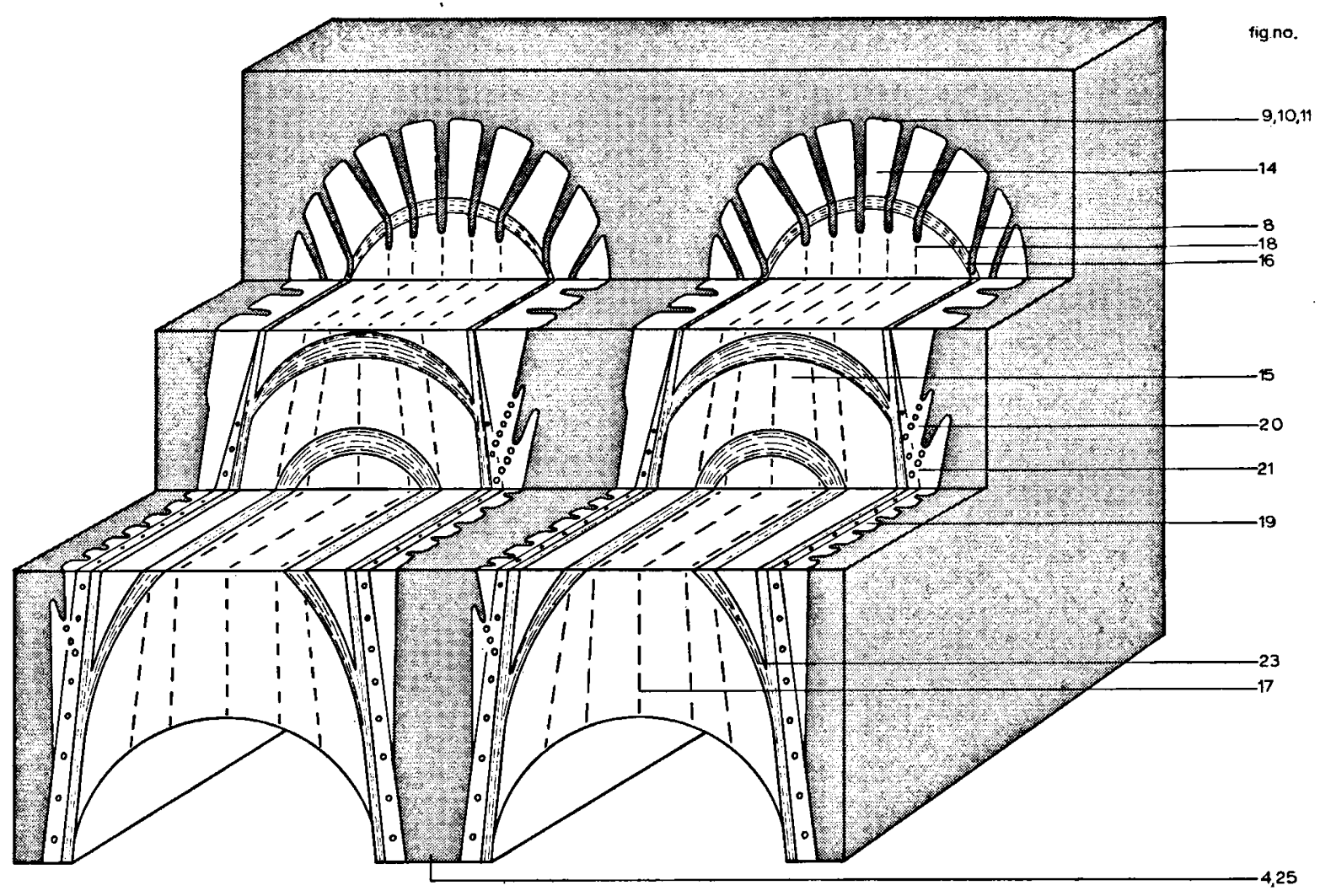

Fig. 6. Scheme of the "roots" of two baleen plates, partly based on fig. 5. The figure numbers indicate the origin of the various figures.

covering layers is called "medulla". These terms were already used by Eschricht and ReinhardT (1861, 1866) and Tullberg (1883) and were adopted by Rưd $(1940,1945)$.

Especially the terms "pulpa" and "enamel" are confusing in connection with the baleen plate, which is an epidermal derivative. These terms are used in dental anatomy. There they are used to indicate components of a total different origin and chemical composition as compared with the components of the baleen plate. In dental anatomy the term "enamel" is used for the hard material of the teeth containing over $40 \%$ of calcium-salts, which forms a cap covering the mass of dentine. In the covering layers of the baleen plate only circ. $1 \%$ calcium and calcium-salts are present (Pautard, 1963). The pulpa, situated in the dental cavity, is a mass composed of connective tissue and blood vessels, covered with epithelium. Though tooth-germs develop in the epithelium, covering the jaws of the foetus of the Balaenopteridae, there are no connections whatsoever between these and the developing baleen plates in the foetus (Dissel-Scherf and Vervoort, 1954; KARLSEN, 1962). The baleen plates are epidermal derivatives, not different from similar structures such as claws, hoofs, nails, horns and hair.

Instead of the name "pulpa" the term "corium wall" is suggested for this component, as it can be compared with the corium walls formed by the subepidermal connective tissue of the skin. For the part of the baleen plate called by Ruud (1940) "enamel", the term "cortex" is suggested as contrasted with the "medulla" of the plate which consists of horny tubes (fig. 4). The cortex of the part of the baleen plate embedded in the gum is separated from the corium wall by a thin layer of tissue. This layer continues in the epithelium of the gum (figs. 5, 7, 8). In this "root"-part of the baleen plate thickenings of the cortex are visible opposite to each other on both sides of the plate. The distance between these thickenings varies considerably. Between the "roots" of two adjacent baleen plates the borderline between the epithelium of the gum and the tissue by which it is covered is arched 


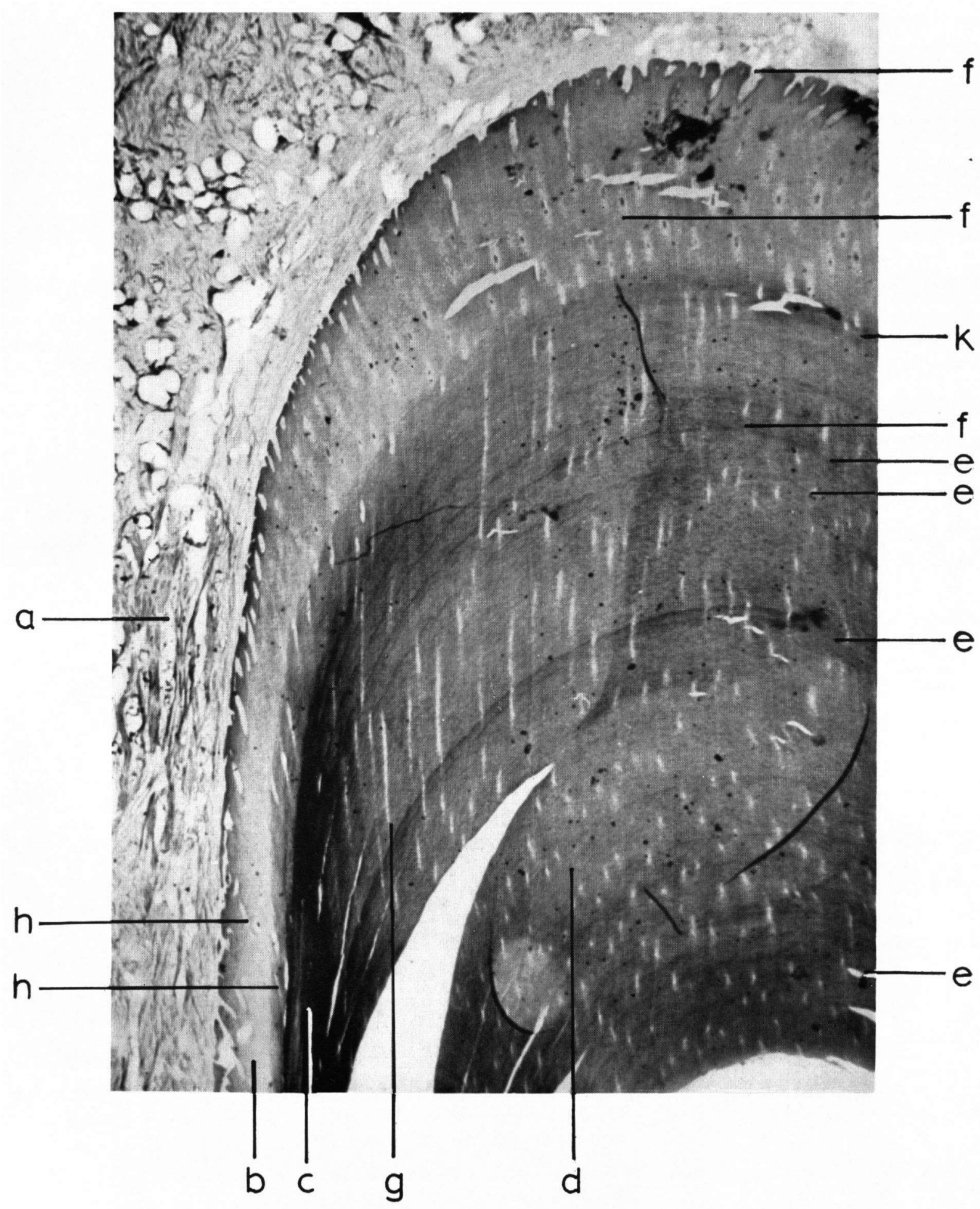

Fig. 7. Section through a part of the "root" of a baleen plate parallel to the longitudinal axis of the plate and perpendicular to its surface. (animal no. W1387, 1953/54). a. corium wall; b. epithelium covering the corium wall; c. cortex; d. gum; e. arched band of flattened cells; f. corium papillae; g. row of spherical cells; $h$. corium lamellae; $k$. zone of flattening of the epithelial cells of the gum. 


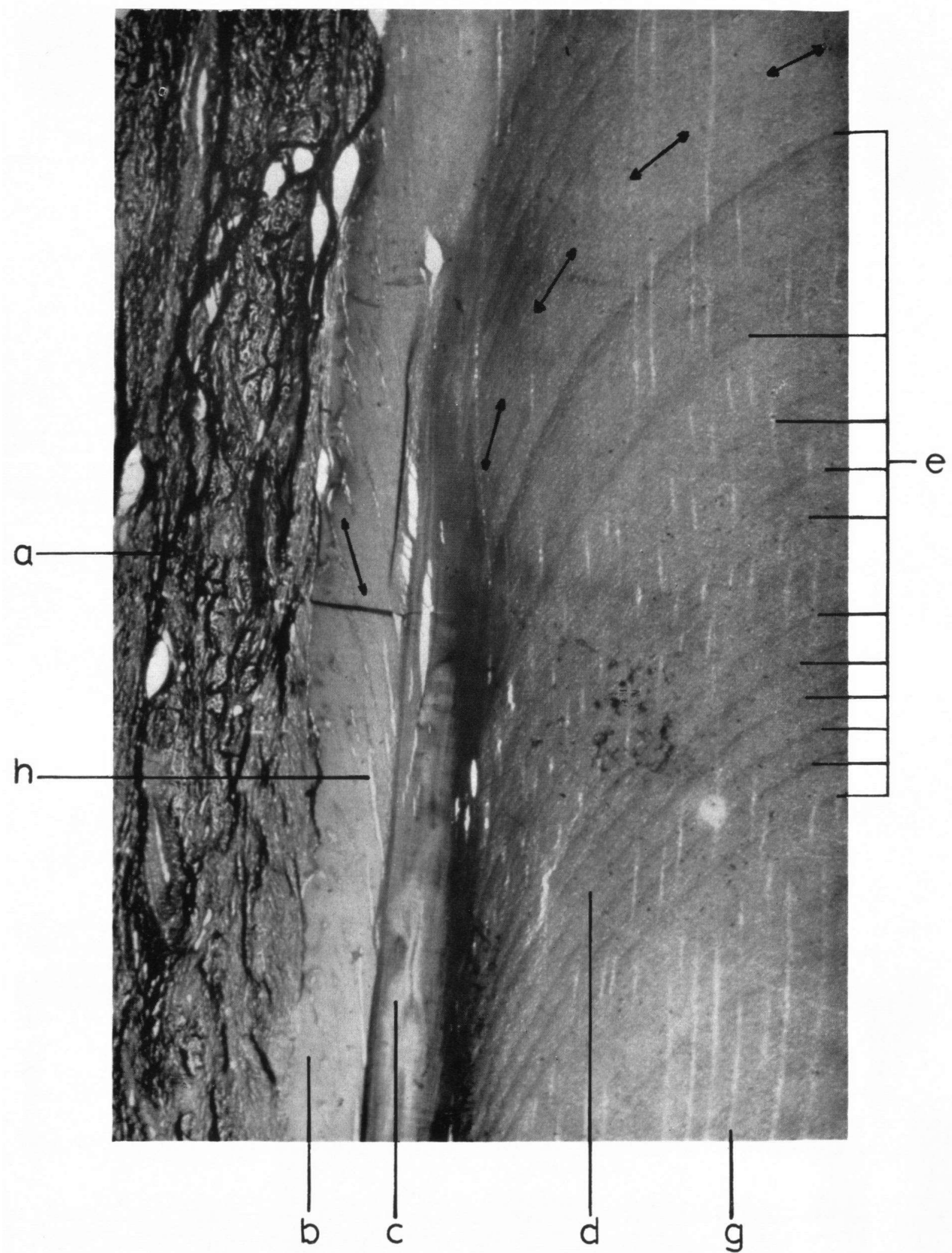

Fig 8. Section through a part of the "root" of a baleen plate of animal no. W1389, 1952/53. Details as given in fig. 7. The arrows indicate the orientation of the longest axis of the cells. 


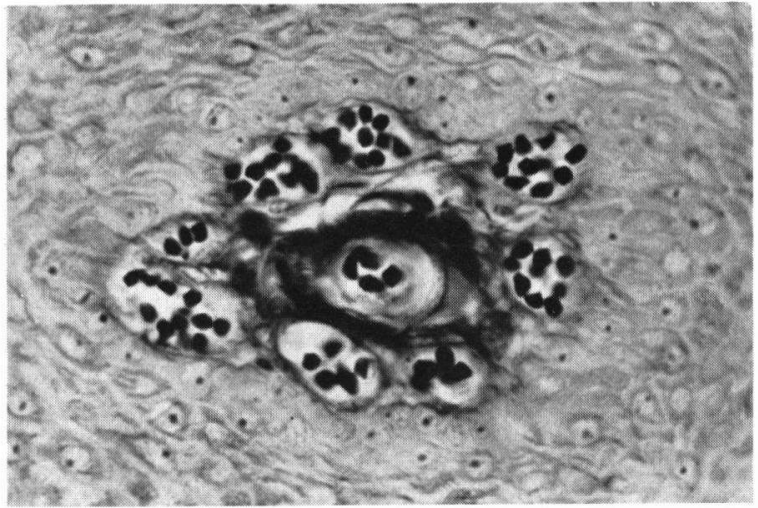

Fig. 10. Transversal section of a corium papilla in the gum. The arrangement of the venules around the central artery is clear.

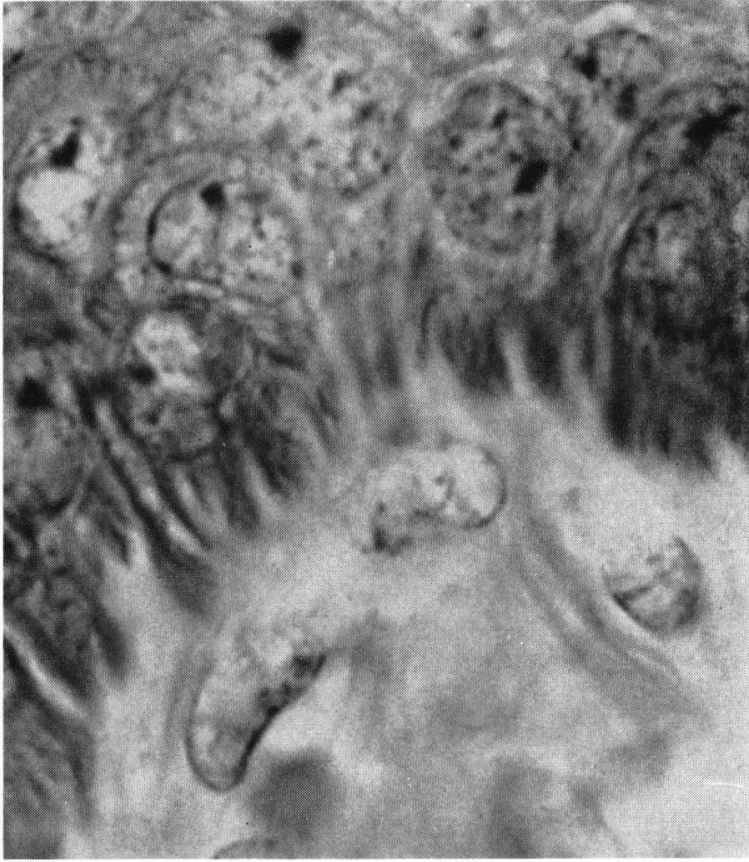

Fig. 11. Stratum basale of the gum of the Fin Whale. The brushlike ends of the cytoplasmatic processes are clear. In these processes spiral filaments are visible. $1200 x$

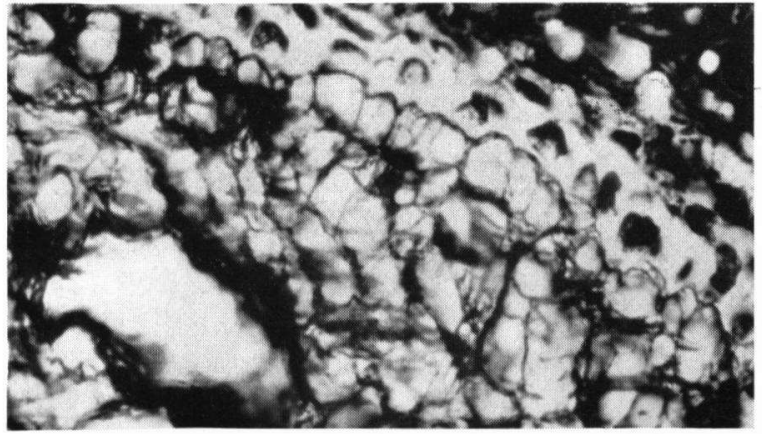

Fig. 12. Argyrophilic network adjacent to the stratum basale of the epithelium of the gum. The "cells" of the network are distinct.
$1000 x$.

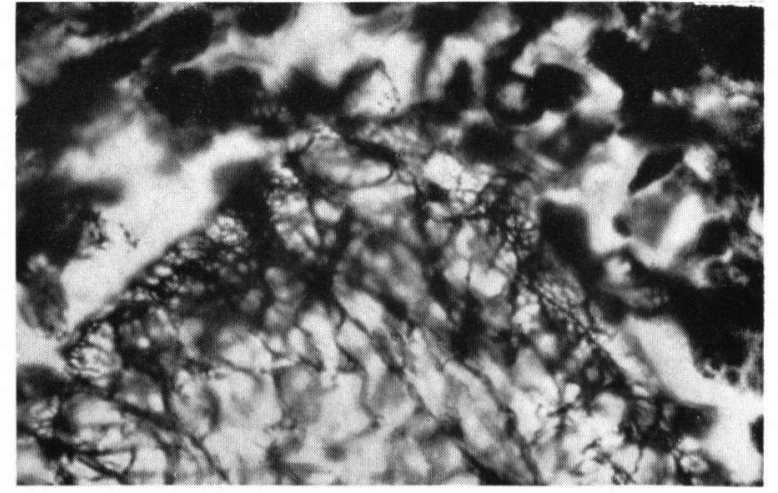

Fig. 13. Fine meshes of the argyrophilic network forming the upper surface of the "cells". 


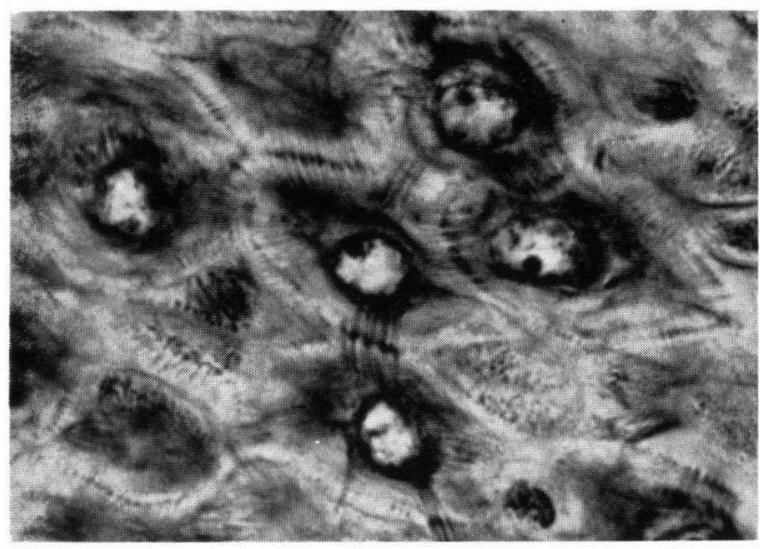

Fig. 15. Deeper part of the stratum spinosum of the Fin Whale. The tonofibrills and transversal sections of them are present. The desmosomes are visible as dark dots. $900 x$.

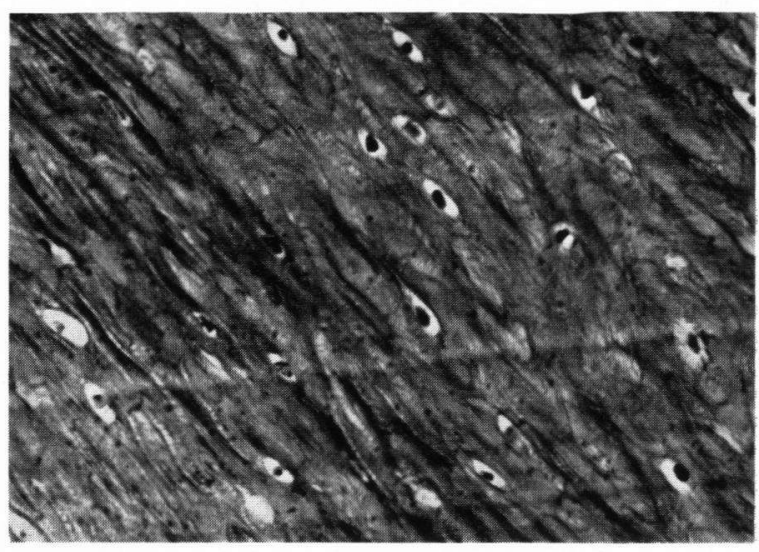

Fig. 16. Higher part of the stratum spinosum of the gum. The tonofibrills present here form coarse bundles. No transversal sections of them are present. $500 x$.

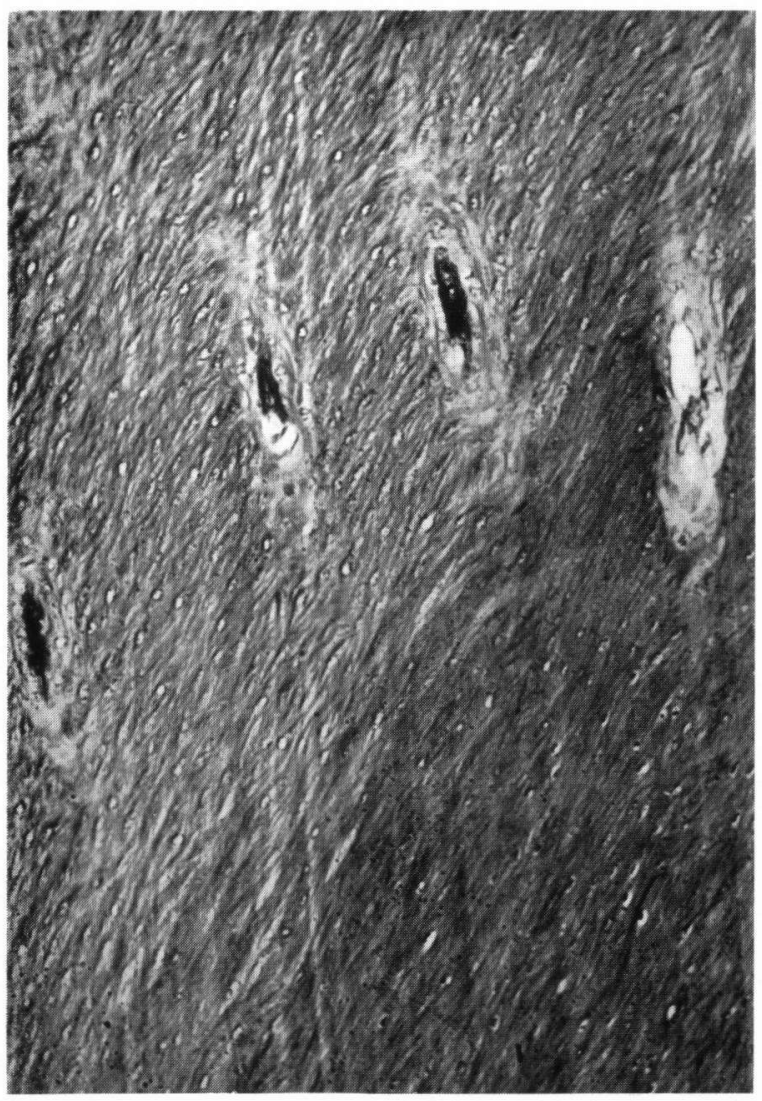

Fig. 17. First zone of heavy flattened cells in the stratum spinosum of the gum. The "border line" is running diagonally from the lower left to the upper right side in the picture. In the right lower part are the darker staining flattened cells.

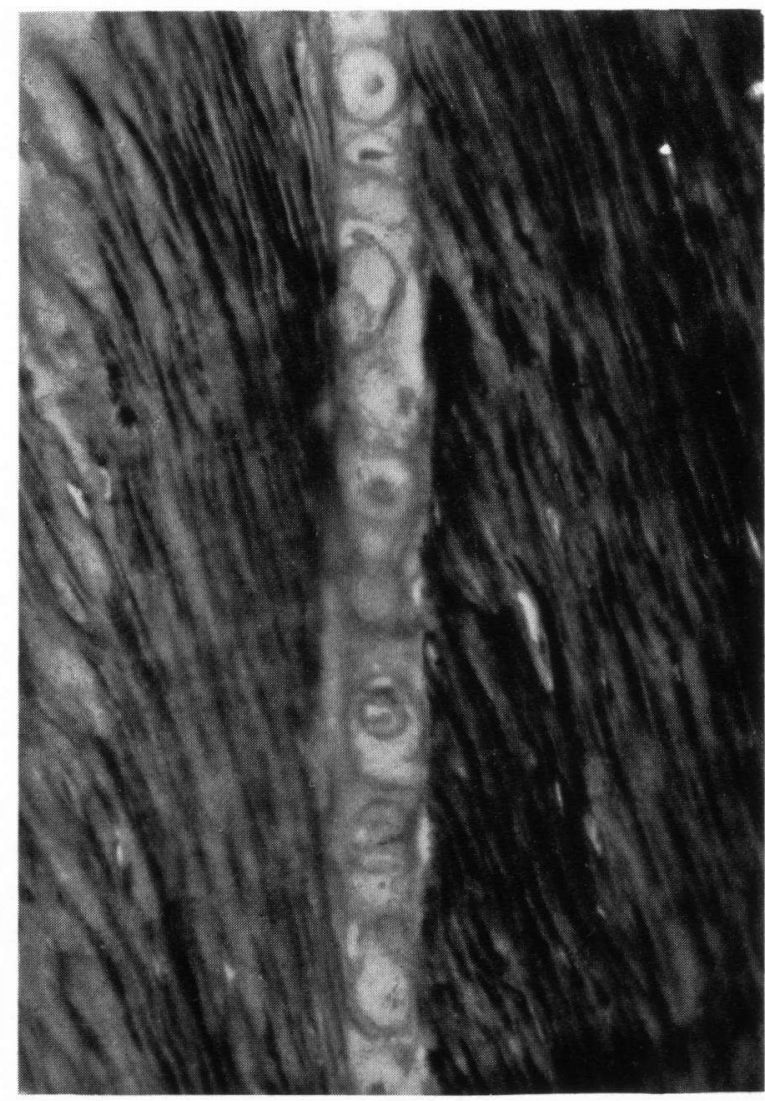

Fig. 19. Globular cells formed on the top of a corium papilla, from the more superficial layers of the gum. $300 x$. 
(figs. $5,7,8$ ). In a longitudinal section a number of fine bands are easy to distinguish in the tissue of the gum. These bands gradually pass into the thickenings of the cortex of the baleen plate (figs. 7, 8). HUNTer (1787) already described these bands as lamellae (see also his fig. 2, pl. XIII). They are arranged into groups. The higher the number of bands is in a group the thicker the cortex of the baleen plate is at the point where they enter into this layer (fig. 8). So each group of bands in the gum is connected with a thickening of the cortex of the baleen plate. The distance between the different groups of bands in the gum varies in the same way as the distance between the corresponding thickenings of the cortex. The groups of bands run in an arch from the thickening of one baleen plate, through the gum, to a corresponding thickening in the cortex of an adjacent plate.

Corium papillae penetrate far into the epithelium of the gum. From the dermo-epidermal border they are arranged radially over a certain distance. Then they bend in such a way that they all run parallel to each other. All epithelial cells formed by the stratum basale on the top of the corium papillae run parallel to the cortex of the baleen plate towards the surface of the gum (figs. 7, 8). From the corium wall in the "root" of the baleen plate corium lamellae, which pass into papillae, penetrate into the epithelium which covers the corium wall. The epithelial cells which are the continuation of these papillae run into the inner layers of the cortex and disappear (figs. $7,8,28)$. This is contrary to what is found for these cells in the gum. Cells formed on top of a few papillae in the gum, in the area where the epithelium which covers the corium wall passes into the epithelium of the gum, extend to the point where the first layers of the cortex of the baleen plate are formed. These cells also run into the cortex of the baleen plate and disappear. This was also described for the corresponding cells in the epithelium which covers the corium wall.

In the microscopic sections the decreasing thickness of the epithelium between the corium wall and the cortex, and the increase in thickness of the cortex is clearly visible (figs. $5,7,9$ ).

Examination of the slides in polarized light shows a strong birefringence in the gum, except in the part of the epithelium adjacent to the corium. Some birefringence is also present in the epithelium that covers the corium wall (see page 27; fig. 29). When birefringence is maximum in the gum there is total extinction in the epithelium between the corium wall and the cortex. This is due to a difference in orientation of the birefringent "fibres" in both epi-

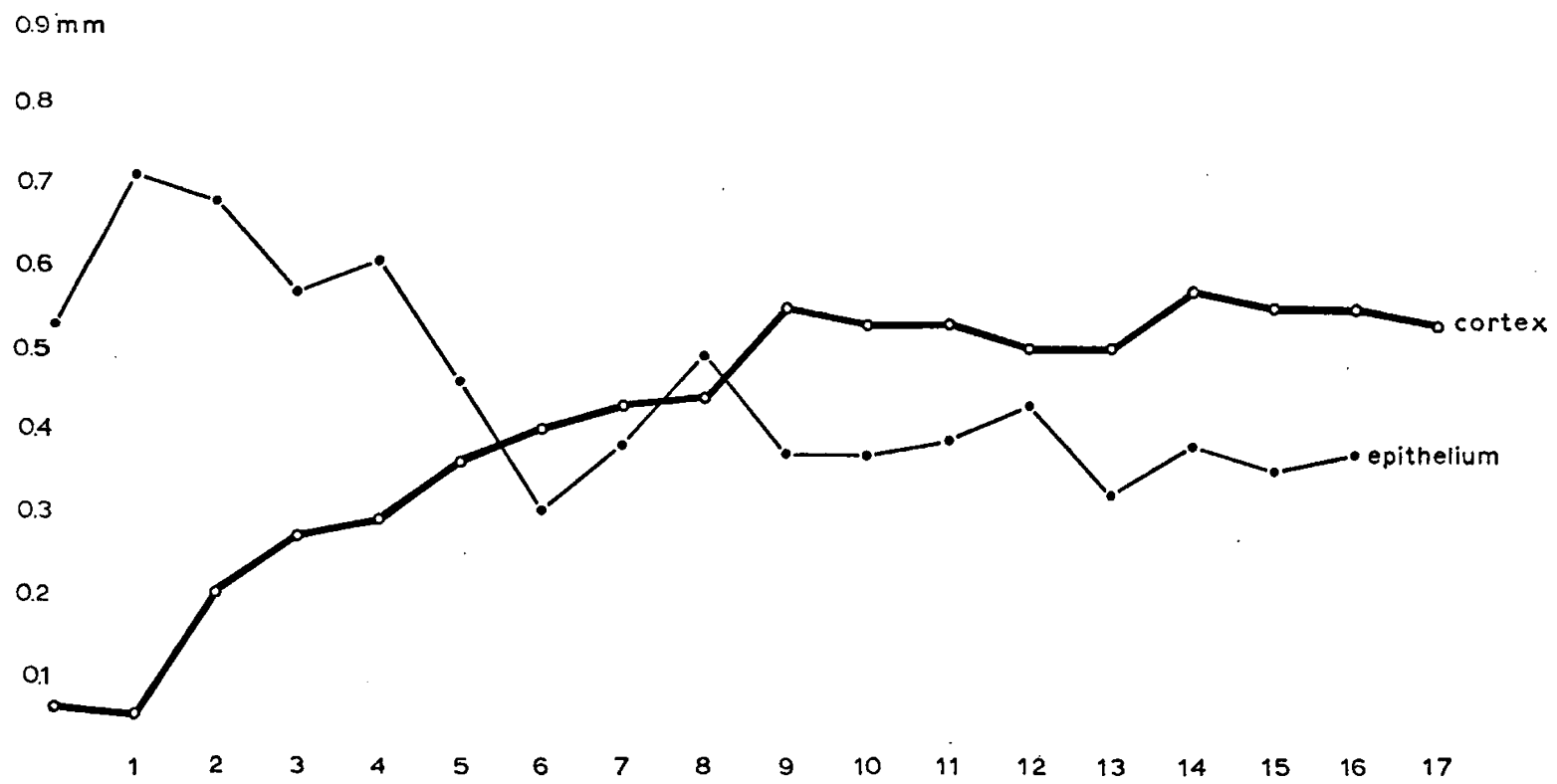

Fig. 9. Diagram showing the changes in the thickness of the cortex and the epithelium covering the corium wall in the "root" of a baleen plate. The measurements are taken at an interval of ca. $5 \mathrm{~mm}$, from the first signs of the presence of the cortex onwards. 
thelia. As the "fibres" in the gum run in an arch from the cortex of one baleen plate to the same layer of the next plate their orientation changes gradually (figs. $7,8,28$ ).

B. HISTOLOGY OF THE DERMIS AND THE EPIDERMAL TISSUE OF THE "ROOT" OF THE BALEEN PLATE

\section{a. The dermis of the gum}

The border-line between the dermis and the epithelium of the gum is very regular in the Fin Whale and the Blue Whale. This holds also good for the dermo-epidermal border in the skin of these animals. Long narrow papillae penetrate far into the epithelium of the gum. These papillae consist of fibres of connective tissue and arterial and venous capillaries. Parry (1949) examined the system of blood vessels in the dermis and the dermal papillae in the Common Porpoise and the Fin Whale. According to his opinion this system in the dermis of these Cetacea is not very complex. From this dermal system arteries and venae run into the dermal papillae. Then these blood vessels become capillaries. The blood vessels in the dermal papillae are arranged in a typical way. A transversal section of the dermal papillae shows an artery situated in the centre of the papillae surrounded by a number of venous vessels, which form a plexus (fig. 10) (van Utrecht, 1958).

Scholander and Schevill (1955), Scholander and Krog (1957) and Scholander (1958) described the same arrangements of arteries and venae in the flippers, flukes and the dorsal fin of the Cetacea and in the extremities of Seals and the Sloth. In these cases, however, the vessels lie deeper in the tissue under the epidermis. In their opinion this arrangement of the blood vessels, according to the principle of countercurrent heat exchange between the artery and the venae, keeps the loss of the body-heat as low as possible or suitable.

The epidermis of mammals is avascular. In most cases, however, it is a comparatively thin epithelium. Consequently the blood vessels need not penetrate far into this epithelium, as diffusion of the nutritients needed for the maintenance seems to be sufficient. In mammals with a thick epidermis, as for instance Hippopotamus and Cetacea, long papillae of a small diameter penetrate into the epithelium. In the epidermis of these animals the number of papillae per square centimeter is high. In the extremely thick epithelium of the gum and also in the epidermis of the Fin Whale and the Blue Whale, the corium papillae with blood vessels penetrate very deep, obviously in order to guarantee the supply of nutritients.
The corium wall in the "root" of the baleen plate can be compared with the corium ridges of the dermis of the skin. On the edge of the corium wall long papillae are found. These consist of connective tissue and blood vessels and are covered by epithelium. On the sides of the corium wall lamellae are found which change into papillae. The blood vessels in these papillae show the same arrangement as was described for the corium papillae of the gum (figs. $10,20)$. On the papillae of the edge of the corium wall, the horny tubes of the medulla of the baleen plate are formed.

\section{b. The dermo-epidermal junction of the gum}

In animals with a nearly or totally hairless skin the system of ridges and papillae of the epidermis is well developed. This is not the case with animals with a hairy skin as, for instance, the rat and the mouse. The hair follicles of the epidermis of these animals probably fulfil the function of connecting the epidermis with the dermis, just like the above mentioned ridges and papillae (Montagna, 1956; Montagna and Harrison, 1957; Medawar, 1953).

In the opinion of MEDAwar there is a correspondence between the thickness of the epidermis and the development of the system of ridges and papillae of the dermis. In a thick and hairless epidermis the corium ridges are high and narrow and the papillae long and thin, whereas in a hairy skin the ridges are broad and low and papillae are absent. This fits in very well with what is found for the dermal structures of the Cetacea.

From the cells of the basal layers of the stratum basale of the gum radicles run into the dermis (fig. 11). Weiss and FerRis (1954) demonstrated that in the skin of larvae of Amphibia the basement membrane is composed of a number of layers of fine fibrils which are at right angles to each other in the successive layers. PEase (1951) on the other hand, found that in the skin of mammals the collagen fibrils of the dermis are situated direct under the basal cells of the epithelium. In the dermo-epidermal border of the epithelium of the gum of Whales no trace of a basement membrane as described by WeIss and Ferris is found, nor are there any structures which could be an indication of such a membrane. This may, however, be caused by the histological techniques applied and by the resolution power of the microscope used. The dermo-epidermal border of the gum of the Fin Whale and the Blue Whale shows the same features as those described by Pease for mammals. 
The radicles of the cells of the stratum basale in the dermo-epidermal border are well developed in the epithelium of the gum. They reach a maximum length of circ. $8 \mu$. Very fine detailed structures are visible in sections stained with the Crossmon technique (fig. 11). The radicles contain spiral filaments which can be seen between the cells of the first two layers of the stratum basale. Where the filaments penetrate the dermis, they fray out and form a brush of very fine threadlike structures.

In the gum the radicles of the basal cells of the stratum basale have a small diameter close to the body of the cell. Their ends are much broader, so as to secure a firm hold in the dermis (fig. 11). Friboes (1920, 1921, 1922; see Montagna, 1956) found that in mammals the basement membrane is an argyrophilic reticulum, the meshes of which contain the cytoplasmatic processes of the basal cells of the epithelium. This is confirmed by Pease (1951) in his examination of the dermo-epidermal border in the skin of mammals by means of the electron microscope.

In the dermo-epidermal border of the gum of the Fin Whale and the Blue. Whale the argyrophilic network can easely be demonstrated (figs. 12 and 13), just as in various parts of the mammalian epidermis.

From a transversal section of the dermo-epidermal border of the gum of the Fin Whale and the Blue Whale, it becomes evident that the argyrophilic network is supported by more or less straight coarse collagenous fibres perpendicular to the dermoepidermal border. These collagenous fibres stand on a mass of collagenous fibres that run more or less parallel to the dermo-epidermal border (fig. 12). Schematically we can use the cubic form with a

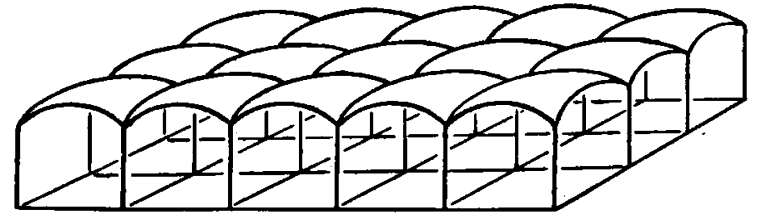

Fig. 14. Scheme showing the cell-like construction of the dermis, adjacent to the epidermis. The dome shaped upper surface of the "cells" is formed by the fine meshed argyrophilic network.

dome-shaped top (fig. 14). This dome-shaped upper surface is formed by an argyrophilic network with fine meshes. The distance between the argyrophilic network and the base of the cells of the stratum basale is smaller than the length of the radicles of these cells $(8 \mu)$. Although not demonstrated, it is reasonable to suppose that the radicles fit into the meshes of the argyrophilic network and in this way firmly attach the epidermal tissue of the gum to its dermis (see also Odland, 1950, 1958; MontaGna and HARrison, 1957).

From the figures 11,12 and 13 it is evident that none of the fibrils of the argyrophilic network penetrates the stratum basale of the epithelium of the gum. This was also stated for other epidermal structures by Dick (1947), Odland (1950) and Pease (1951).

As all "cells" of the argyrophilic network have a convex top and as the development of the radicles of the cells of the stratum basale depends on the forces working on the dermo-epidermal border (ODLAND, 1950), it is reasonable to suppose that the very fine network of the top is kept under constant tension by the "cells" of the argyrophilic network. In this way the radicles of the cells of the stratum basale remain fixed in the fine network of the dermis, so that the epidermis is kept in its position, no matter in what direction forces are working on it. This view is also supported by the fact that the radicles of the basal cells of the epithelium are developed best in those parts of the epidermis on which forces are working, e.g. in the epidermis of the knee, elbow and the joints of the fingers.

\section{c. The epidermal tissue of the gum}

The gum of the Fin Whale and the Blue Whale is a normal epidermal tissue, which consists of a number of more or less different types of cells, arranged in such a way that division into a number of layers is possible.

The normal mammalian epidermal tissue consists of three layers: the stratum basale, the stratum spinosum and the stratum corneum. In certain areas of the skin, for instance in the sole of the feet, another two layers are found, between the stratum spinosum and the stratum corneum. These are the stratum granulosum and the stratum lucidum.

In the epithelium of the gum of the Fin Whale and the Blue Whale only the stratum basale and stratum spinosum are present, but no stratum corneum proper. The baleen plates are the only structures in the Mysticeti, which consist of hard horn.

\section{d. The stratum basale of the gum}

The cells in the stratum basale of the gum are more or less cylindrical. Without the radicles the body of these cells is circ. $16 \mu$ long and circ. $5 \mu$ broad. The longest axis of the cells is perpendicular to the dermoepidermal border. The cells further away from this border are less flattened and therefore they have an oval form or are round. The radicles of the cells of 
the first five layers of the stratum basale run into the argyrophilic network. The radicles of the cells of the second up to the fifth layer run in between the cells of the more basal layers (fig. 11).

In the different stain-techniques applied, the cells of the stratum basale of the gum stain somewhat darker than those of the deeper parts of the stratum spinosum which is adjacent to the stratum basale of the same epithelium. In the first five layers of the gum, the stratum basale, the fibrillary system is well developed. No nodes of Bizzozero (desmosomes) are visible, and no fibres in a form like those in the stratum spinosum are found. In the epithelium of the gum of the Fin Whale and the Blue Whale no connections between the fibres of the radicles of the stratum basale with the tonofibrils of the stratum spinosum are found. The stratum basale of the gum can be defined as the layer of cells in the epithelium where no tonofibrils are visible, though fine filaments which run in all directions, are visible in the cells. Desmosomes are not visible but radicles from the basal cells penetrate into the sub-epidermal tissue.

\section{e. The stratum spinosum of the gum}

The stratum spinosum of the gum in the Fin Whale and the Blue Whale is characterized by the enormous development of the tonofibrils, while desmosomes are present in the walls of all cells of this stratum.

With the term tonofibrils the coarse fibrillary structures are meant which are composed of albumin chain molecules, condensed to coarse threads and bundled in comparatively thick fibrils in a cell. The tonofibrils are covered by the cell membrane. They run from a desmosome in the cell membrane at one side of the cell to a desmosome on the other side. They run in a definite direction and are taut structures.

Filaments are wavy, comparatively thin threads in a cell which run in all directions through the cell. They show no particular direction, as tonofibrils do, and form a felt-like structure in the cell. In a section, in the deeper layers of the stratum spinosum, perpendicular to the surface of the cortex and parallel to the longitudinal axis of the baleen plate, the tonofibrils run in all directions and also transversal sections of them are present in the cells (fig. 15). This is not the case in the higher layers. Here the tonofibrils run in a definite direction. This becomes even more distinct as the distance to the dermoepidermal border increases. At last all tonofibrils bundled together, run parallel to this border while transversal sections of them are no longer visible in the cells (fig. 16). Another characteristic feature of the cells of the stratum spinosum are the desmosomes (nodes of Bizzozero) in the walls of the cells. These structures are not present or not visible in the cells of the stratum basale. A border-line can be drawn at the place where the desmosomes become visible. In the more superficial layers of the gum the cells of the stratum spinosum become more and more flat. The cells are not transformed into a stratum lucidum or stratum granulosum and a stratum corneum. In these layers of the stratum spinosum also the nuclei of the cells become flat and at last pycnotic. Here the cells consist of a wall and a bandlike remnant of the nucleus. Furthermore they are filled with fibrillary material.

In most Fin Whales and Blue Whales, in the pieces of the gum, which contain the "root" of the baleen plate, and in most microscopic sections of this part, a line runs from the origin of the cortex of a baleen plate to the same point of an adjacent plate. The part of the epithelium of the gum between the dermoepidermal border and this line, which contains the stratum basale and a part of the stratum spinosum, stains lighter in the microscopic sections than the part between this line and the surface of the gum, which only consists of stratum spinosum.

This line does not run exactly parallel to the dermo-epidermal border, both ends being closer to this border than the part in the centre of this arched line.

The part of the epithelium of the gum between the dermo-epidermal border and this arched line, which is about 1-3 mm thick in the centre of the arch, decreases gradually in thickness and continues into the epithelium which covers the corium wall. At the base of this wall the epithelium is circ. $1 \mathrm{~mm}$ thick, measured from the dermo-epidermal border to the end of the arched line at the origin of the cortex (figs. 7, 8).

In the stratum spinosum there is a marked change in the direction of the greatest diameter of the cells. Together with this there is a change in the directions of the tonofibrils. In the basal layers of this straturn the cells have their greatest diameter perpendicular to the dermo-epidermal border.

This is the same as in the stratum basale. This direction is also the main direction of the growth of the epithelium.

At a regular interval of $120 \mu$ measurements were taken of the cells of the stratum basale and stratum spinosum between the dermo-epidermal border, and a point deep into the epithelium of the gum. This is done along a line parallel to the course of the 

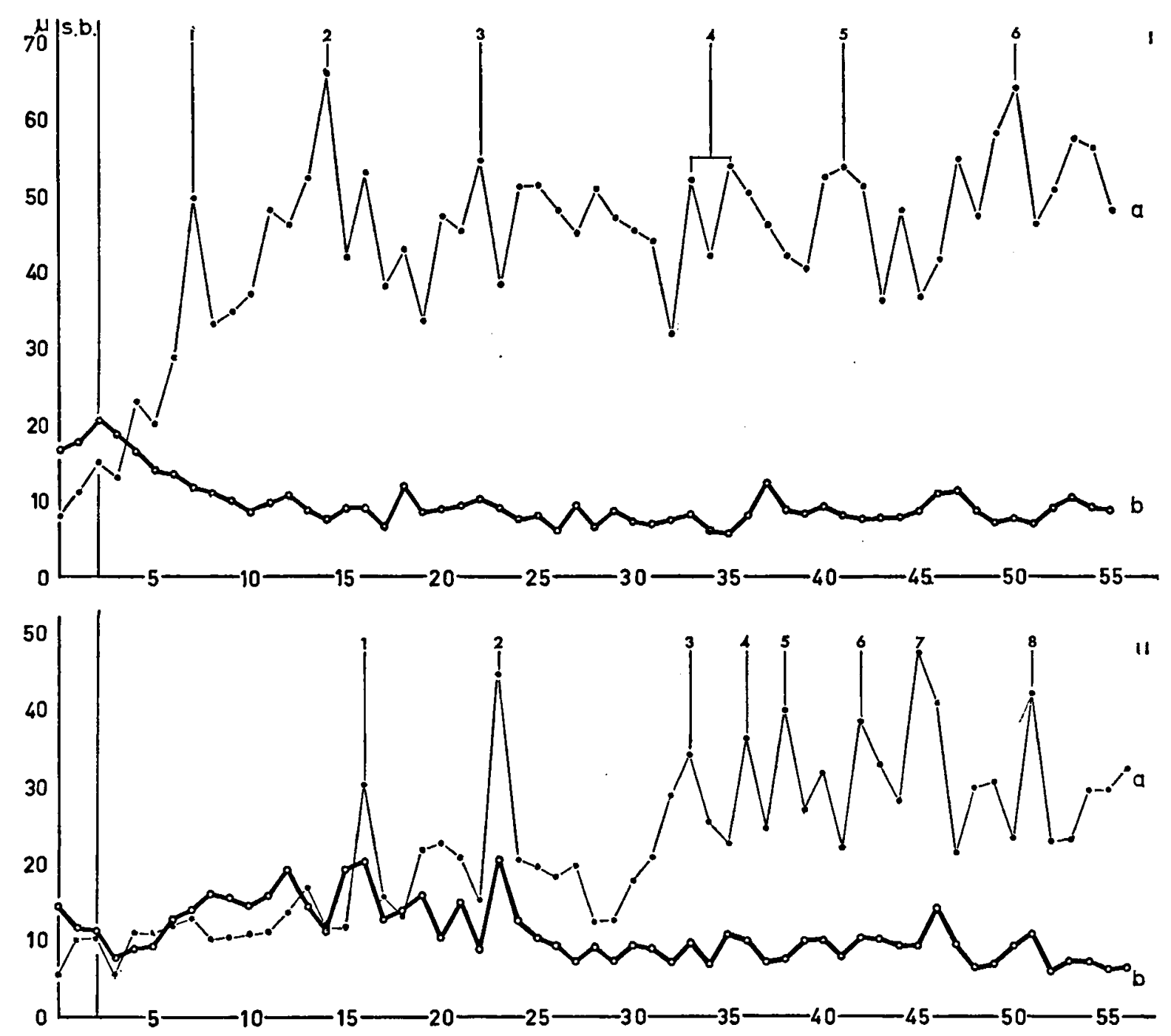

Fig. 18. Diagram I (animal no. W1387, 1953/54) and II (animal no. W1389, 1952/53) represent the lengths of the cells in the gum, measured in the direction parallel to the dermo-epidermal border (a), and perpendicular to the dermo-epidermal border $(b)$. The measurements are taken along a line parallel to the cortex from the dermo-epidermal border into the gum, at regular intervals of $120 \mu$. Ordinate: size of the cells in $\mu$. The numbers $1,2,3$, etc., indicating the peaks in the curves correspond with "bands" of flattened cells in the gum. The curves clearly show the great individual variations. See also fig. 7 and $8 .(s . b .=$ stratum basale)

corium papillae in the basal layers of the epithelium of the gum, and in the more superficial layers parallel to the cortex. The directions in which the measurements were taken were parallel to the dermoepidermal border and perpendicular to this border. As an example, the results for two female Fin Whales are given in fig. 18. From these and corresponding measurements taken on slides of other animals, it is evident that great individual variations exist, which are also found in the measurements of the thickness of the baleen plates, thickness of the cortex, etc.

The curve representing the measurements of the cells taken in a direction perpendicular to the dermoepidermal border, is rather smooth compared with the curve of the measurements of the cells in a direction parallel to the dermo-epidermal border.

The measurements taken in the direction perpendicular to the dermo-epidermal border show that in 
this direction the diameter of the cells of the stratum basale increases from circ. $16 \mu$ to $20 \mu$. The measurements taken in the direction parallel to the dermoepidermal border show an increase of the diameter of the cells from circ. $8 \mu$ to circ. $15 \mu$. It is evident that the cells of the stratum basale are cylindrical with the greatest diameter perpendicular to the dermo-epidermal border. It is also evident that the cells of the stratum basale grow in size. There is, however, a decrease in the diameters of the cells in the stratum spinosum in the direction perpendicular to the dermo-epidermal border from circ. $20 \mu$ to circ. $7 \mu$. In the further course of the curve there are only slight variations in the diameters of the cells. The measurements taken in the direction parallel to the dermo-epidermal border show great variations in the diameters of the cells of the stratum spinosum of the gum. At first there is a rapid increase to circ. $50 \mu$. This point is at a distance of circ. $1 \mathrm{~mm}$ from the dermo-epidermal border and corresponds with the arched line (see p. 16), which is visible in the microscopic sections of the gum (fig. 17). From here in the diameters of the cells of the stratum spinosum in the direction parallel to the dermo-epidermal border, great variations exist as is shown in the curve. The minimum is circ. $22 \mu$ and the maximum circ. $65 \mu$. All peaks in the curve correspond with similar lines in the tissue as for instance with the line at $1 \mathrm{~mm}$ distance from the dermo-epidermal border. All lines are marked by arabic numerals. The peaks in the curve representing the diameters of the cells in the direction parallel to the dermo-epidermal border, really always correspond with a slight decrease of the diameters of the cells in the direction perpendicular to the dermo-epidermal border. This is a clear indication that the lines in the gum are caused by extra flattening of the cells of the stratum spinosum. Besides the great individual variations, in all animals there is a decrease in the size of the cells at a distance from circ. $240 \mu$ from the dermo-epidermal border. This corresponds with the presence of the first cells of the stratum spinosum. Also, if there is a line in the stratum spinosum between the beginning of the cortex of two adjacent baleen plates it is always at a distance of circ. 1-3 $\mathrm{mm}$ from the dermoepidermal border. Examination shows that the lines mentioned above, consist of cells of the stratum spinosum which are more flattened than those at other points in the epithelium of the gum, and that these lines also end in the thickenings of the cortex. It seems that the cells are spread sideways under the influence of the flattening forces, in the direction of the cortex of the baleen plate. As was already de- scribed above, the corium papillae consisting of connective tissue, arteries and venae, penetrate very deeply into the gum. These papillae are important in the emission of body heat when water flows along the baleen plates and the gum. The artery, surrounded as it is by venae, may limit this (see also Scholander and Schevill, 1955; Scholander and KROG, 1957; Scholander, 1958; van Utrecht, 1958). Along their whole length the papillae are covered by two layers of cells of the stratum basale. Cells formed here very soon become indistinguishable from the surrounding cells of the stratum spinosum. The tops of the papillae reach beyond the line where the cells of the stratum spinosum become flattened. This line forms a border line between the deeper part of the epithelium that stains light, and the more superficial part of the epithelium that stains darker. Also on the tops of the papillae cells are formed. These cells never become flattened in the more superficial layers of the gum. Even near the surface of the gum they can be recognized as rows of globular cells (fig. 19). Each row of them originates at the top of a papilla. These rows run parallel to each other as well as to the surface of the cortex (see figs. 7, 8, 28). From these facts it is evident that compression and consequently flattening of the cells of the stratum spinosum of the gum only occurs in a zone between the corium papillae. This zone is marked by the above mentioned sudden change in the intensity of staining. The border line between the two areas of the stratum spinosum, marked in this way, ends on both sides of the gum in the very first part of the cortex of two adjacent baleen plates (figs. 6, 7, 8).

In the stratum spinosum of the gum the tonofibrils run through the cells in all directions, particularly in the more basal layers of this stratum. The nucleus of these cells is enclosed by these fibrils. The tonofibrils run from the desmosomes in the cell membrane at one side of the cell to the desmosomes at the other side. Charles and Smiddy (1957) described the same features for other mammals. In their opinion the tonofibrils of two adjacent cells are in contact with each other by means of the desmosomes, and in this way form a continuous supporting system. Consequently their mechanical characteristics can be fully utilized. In the opinion of SALECKER (1943), the tonofibrils are arranged in such a way that in the epidermis they have an arched course in the stratum spinosum. The stratum basale and stratum corneum have their own fibrillary system independent of the former. When forces are working on the epidermis these fibrillary systems maintain the connection between the cells of the epithelium. 
This conception implies that the system of tonofibrils is more or less rigid and that it runs through all layers of the epithelium, in which cell divisions and consequently increase of the number of cells occurs. It is shown that cell divisions occur in the stratum basale and stratum spinosum of the epidermis (HorstmanN, 1957, in "Handbuch der Mikroskopischen Anatomie des Menschen"; PInkus, in Rothman, 1955). If the system of tonofibrils is such a constant and rigid network, in which the fibrils cross each other (SALECKER, 1943), there are not many possibilities for the cells to move during cell division. Unless, it is supposed that the network of tonofibrils is subject to continuous changes. These changes must occur in such a way that the continuity in the fibrillary system is interrupted for a while when new cells are formed. Consequently the speed of such changes has to be adapted to the speed of the movements of the cells (HorstmanN, 1957).

In the stratum spinosum of the gum of the Fin Whale and the Blue Whale the desmosomes are of the same size as those in the stratum spinosum of the human epidermis. The average size of the desmosomes in the stratum spinosum of the gum is $0.4 \mu$ with a minimum of $0.24 \mu$ and a maximum of $0.70 \mu$. This rather great variation can be attributed to the fact that not all desmosomes are exactly in the plane of the section. The size of the desmosomes in the stratum spinosum of the human epidermis obtained by means of electron-microscopical examination (ODLAND, 1958) varies from $0.3 \mu$ to $0.7 \mu$. Both results correspond with each other.

As was said above the corium papillae that penetrate the epithelium of the gum, are covered with a stratum basale which consists of two layers of cells. Cells formed by this stratum are not different from the cells of the stratum spinosum of the gum.

On the tops of these corium papillae the situation is different. Cells formed here by the stratum basale are formed beyond the line where compression of the stratum spinosum can occur, and consequently flattening of this stratum. Therefore, the cells formed by the stratum basale on the tops of the corium papillae, maintain their globular form. In these cells close to the tops of the corium papillae, tonofibrils are not visible. However, desmosomes are present in the walls of these cells. These cells are full of filaments which follow a wavy course and run in all directions. In a number of cells the development of tonofibrils is visible. In the parts of the walls of these cells directed to the tops of the corium papillae, only desmosomes are visible. From this side of the cell to the opposite side, the desmosomes become more and more distinct, and the wall of the cell in between these structures becomes more and more concave. The fibrillary material in these cells, however, does not show any distinct direction except close to the desmosomes (fig. 20).

Between the opposite desmosomes of adjacent cells, near the tops of the corium papillae in the stratum spinosum of the gum, indications of a constriction or an interruption are visible. These are not clearly defined as magnification and resolving power of the optical instruments used are not sufficient to see these extremely fine details clearly (fig. 20). In an electron-microscopical examination of the human epidermis Odland (1958) showed that desmosomes are complicated structures. In the cell membrane he found rather thick, dark disks. Similar disks are present in the membrane of the adjacent cell on the opposite side of the intercellular space. In the intercellular space between the two disks there are a number of structures of different density. The structures are parallel to both, desmosomes and cell membranes. In between the structures of higher density there are a number of structures of lesser density. Consequently continuity of the tonofibrils through a number of cells is not possible. The fibrils of one cell end in the desmosomes.

C. HISTOLOGY OF THE DERMIS AND THE EPIDERMAL TISSUE COVERING THE CORIUM WALL, AND THE CORTEX OF THE BALEEN PLATE

The epithelium that covers the corium wall consists of a stratum basale and a stratum spinosum. The horny cortex can be considered as a stratum corneum. In this epithelium there is no stratum lucidum and no stratum granulosum.

As was already described above (p. 13) the thickness of the epithelium that covers the corium wall in the "root" of the baleen plate decreases from the base of this wall to its rim (figs. 5, 6, 7). In this epithelium bundles of flattened cells do not exist. Neither there are tonofibrils visible in the cells. This is contrary to what is found in the gum. This epithelium shows a very regular overall "density" of staining, which is contrary to what is found in the epithelium of the gum between two baleen plates, although both are cutaneous epithelia, which are even closely connected. From the corium wall lamellae, composed of connective tissue fibres and bloodvessels, penetrate into the epithelium (figs. 7, 21). This is also found in the hoof of the horse (ZIEGLER, 1951). These lamellae split into secondary lamellae. At their distal ends these lamellae pass into papillae. The rims of the lamellae as well as the papillae and 
the rows of globular cells formed on the tops of these papillae, run in a direction not parallel to the longitudinal axis of the baleen plate. They run from the corium wall to the cortex of the baleen plate, and the rows of globular cells enter it at a small angle. In a transversal section both lamellae and papillae are found in the sequence corium wall, lamellae, papillae (fig. 21). The blood vessels in these lamellae and papillae are arranged in the same way as in the corium papillae in the gum and in the papillae on the rim of the corium wall (figs. 10, 21).

It is evident that the speed of growth of the baleen plates and gum on the one hand of the baleen plate and the epithelium between the cortex of this plate and the corium wall on the other hand, is equal. Otherwise, the epithelium of the gum or the epithelium covering the corium wall would be torn.

As was described above, however, there are strong connections between the epithelium of the gum and the cortex of the baleen plate. As will be shown below, the same holds good for the epithelium that covers the corium wall and the cortex. The increase in length of the cells of the epithelium that covers the corium wall, seems to be regular. In this epithelium no bands of extra flattened cells are present. Close to the inner side of the cortex there is a part of the stratum spinosum that stains somewhat darker than the stratum basale and the rest of the stratum spinosum. In a section through the "root" of a baleen plate parallel to its longitudinal axis and perpendicular to the cortex in that "root", the smallest and greatest diameters of the cells were measured. On the whole the smallest diameter is more or less perpendicular to the dermo-epidermal border of the corium wall and the epithelium that covers this wall. The greatest diameter is in a direction at a small angle with the dermo-epidermal border, which angle opens to the free end of the baleen plate (figs. 8, 24, 25). As the cells of the stratum spinosum in this epithelium come near to the cortex, they become more and more flattened. This holds also good for the nuclei of these cells. At least they are only visible as narrow bands. From a section perpendicular to the longitudinal axis of the baleen plate and perpendicular to its surface (fig. 21) it appears that the cells, which are seen here in a transversal section more or less perpendicular to their greatest diameter, are all of about equal size except close to the cortex. Here they also become flattened in the direction perpendicular to the dermo-epidermal border. This is confirmed by curve $d$ in fig. 23 , which represents the measurements in this direction. The end of this curve, which represents the measurements of the
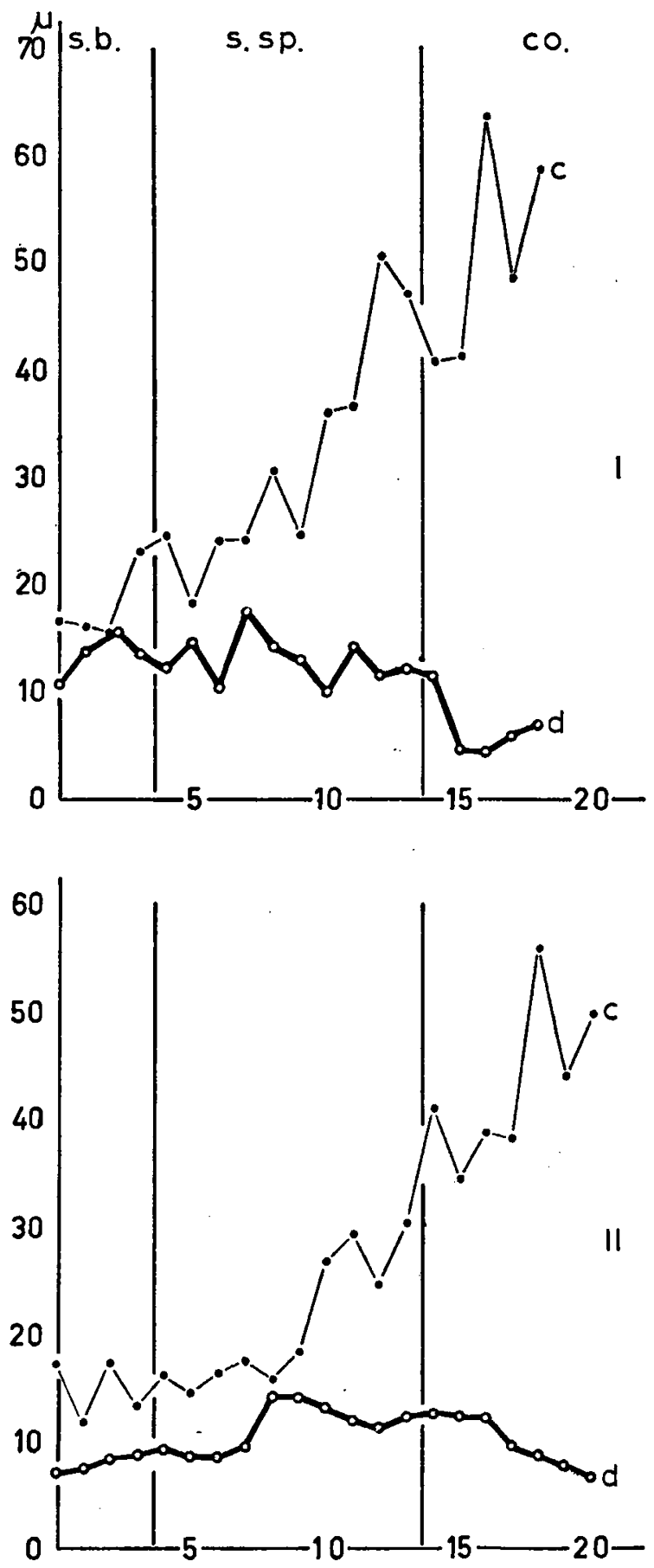

Fig. 23. Diagram I (animal no. W1387. 1953/54) and II (animal no. W1389, 1952/53). Both curves represent the lengths of the cells in the epithelium covering the corium wall, respectively in the direction of the longest axis (c) and perpendicular to this direction (d). The measurements are taken at regular intervals of $120 \mu$ from the dermo-epidermal border onwards, along a line which has the same direction as the longest axis of the cells has (fig. 8, 25). (s.b. = stratum basale; s.sp. = stratum spinosum; c.o. = cortex) 


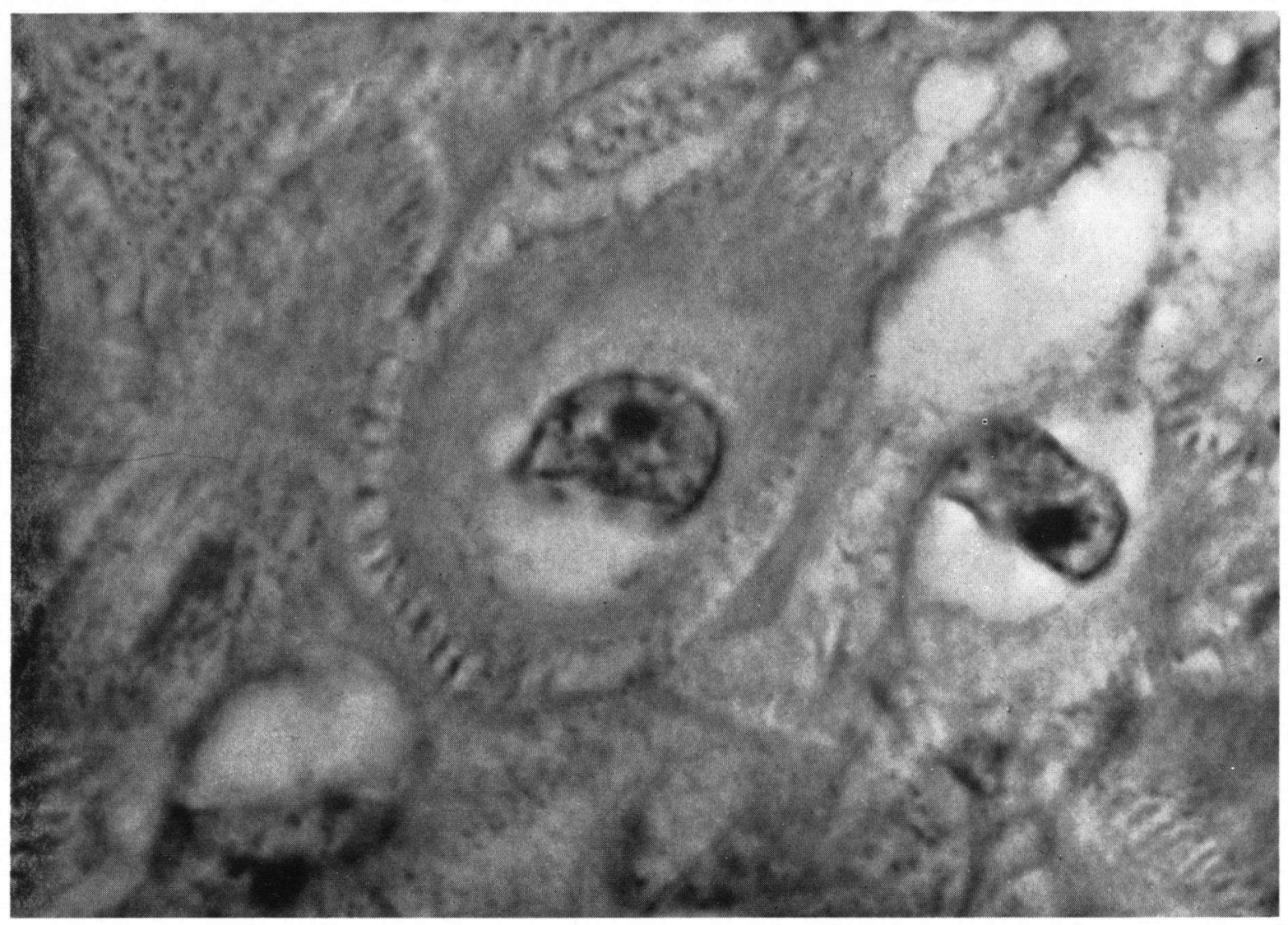

Fig. 20. Epidermal cell close to the top of a corium papilla in the stratum spinosum of the gum. Desmosomes are visible in the cell membrane and also very fine fibrillary structures run through the cell. In the lower half of the cell the development of the prickles is visible. Going to the opposite of the cell the prickles gradually diminish in length. $1500 x$. 


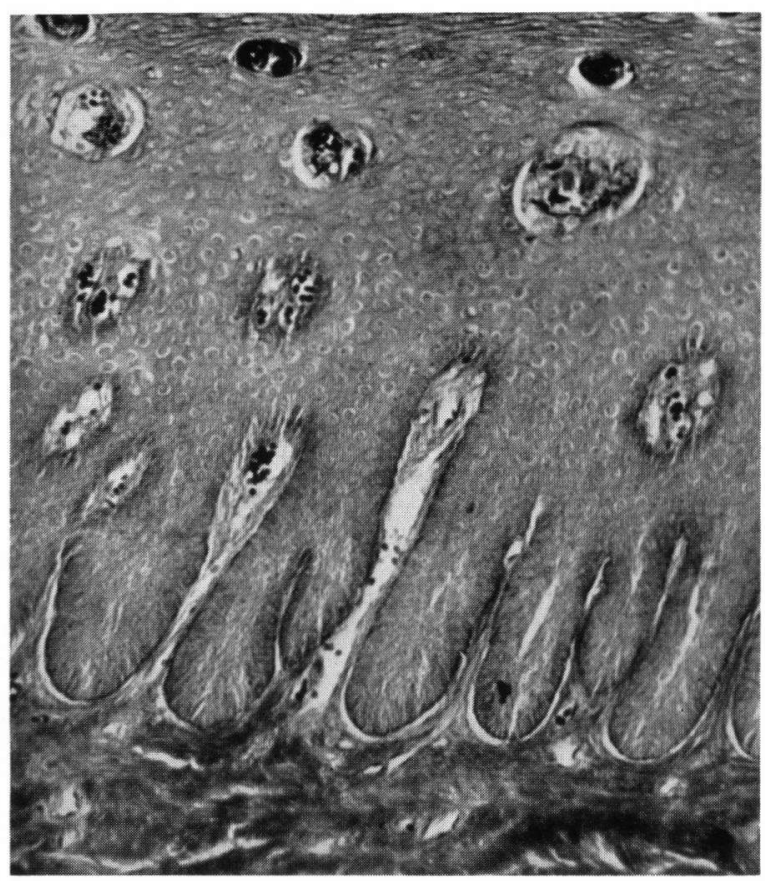

Fig. 21. Section through the epithelium covering the corium wall perpendicular to the longitudinal axis of the "root" of the baleen plate, showing the corium lamellae and papillae. These latter are present as transversal sections.

$250 x$.

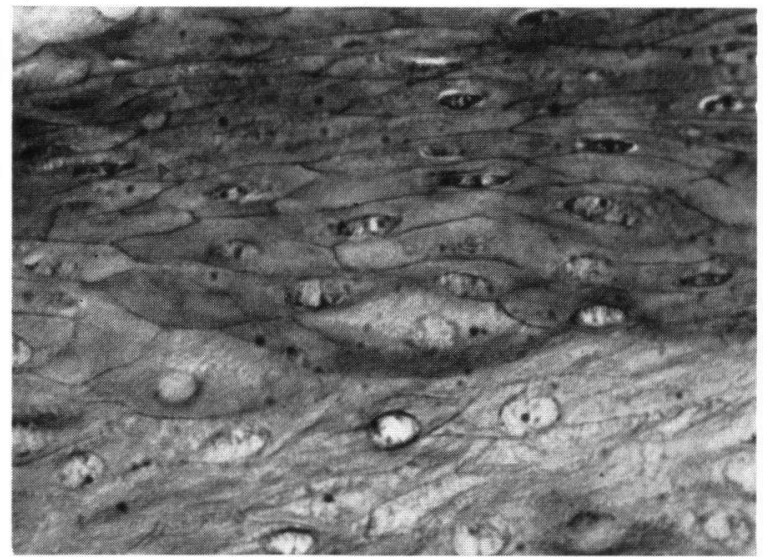

Fig. 24. Stratum spinosum of the epithelium covering the corium wall. The direction in which the section is made is the same as it is in fig. 22. The cortex is immediately below the bottom of the picture. Desmosomes are visible. In particular they are present pressed together to form a dark line (in the lower half of the picture) in the direction of the longest axis of the cells as is also indicated by arrows in fig. 8 and 25 .

$700 x$.

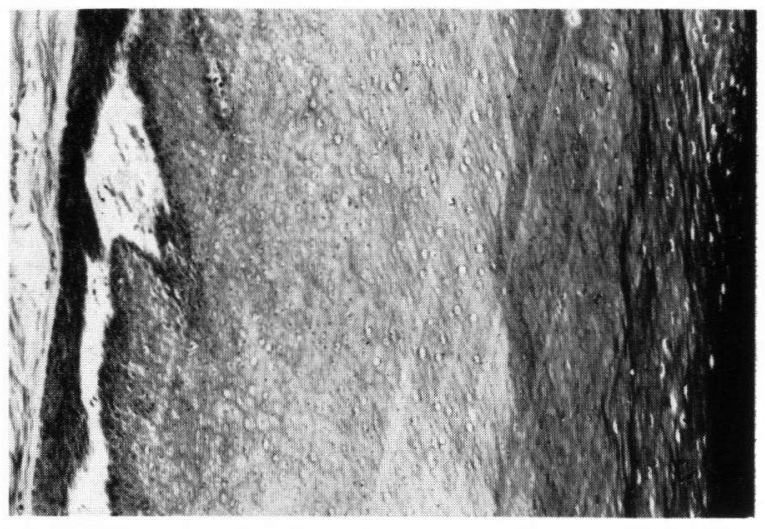

Fig. 22. Epithelium covering the corium wall in a section parallel to the longitudinal axis of the baleen plate and perpendicular to its surface. At the left side is the corium wall, at the right side the cortex. Flattening of the cells in this epithelium is gradual.

$150 x$.

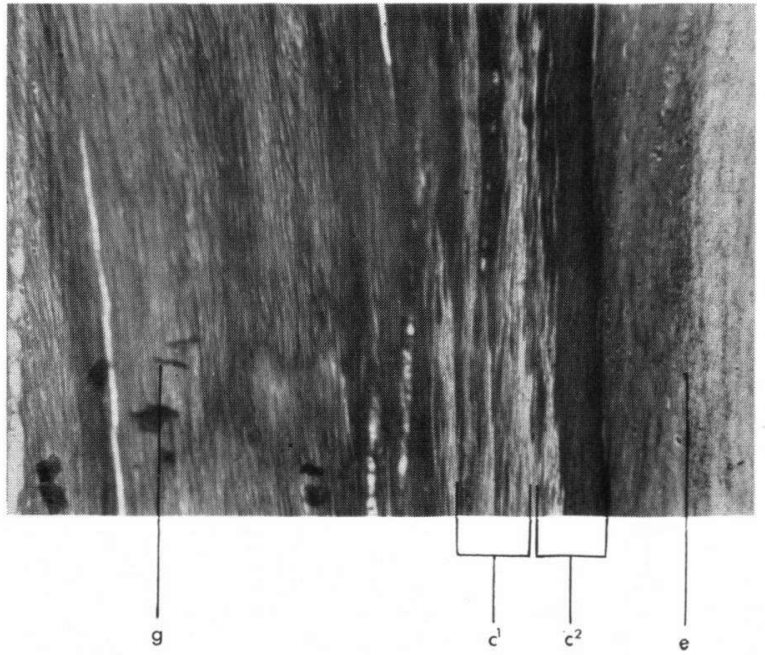

Fig. 26. The cortex in the "root" of a baleen plate in a section parallel to the longitudinal axis, and perpendicular to the surface of the plate. ( $\mathrm{g} .=$ gum; $c^{1}$ and $c^{2}=$ cortex of the baleen plate; $e .=$ epithelium covering the corium wall) The cortex is composed of two layers. Rows of globular cells are present in the gum in the immediate vicinity of the cortex.

$100 x$. 


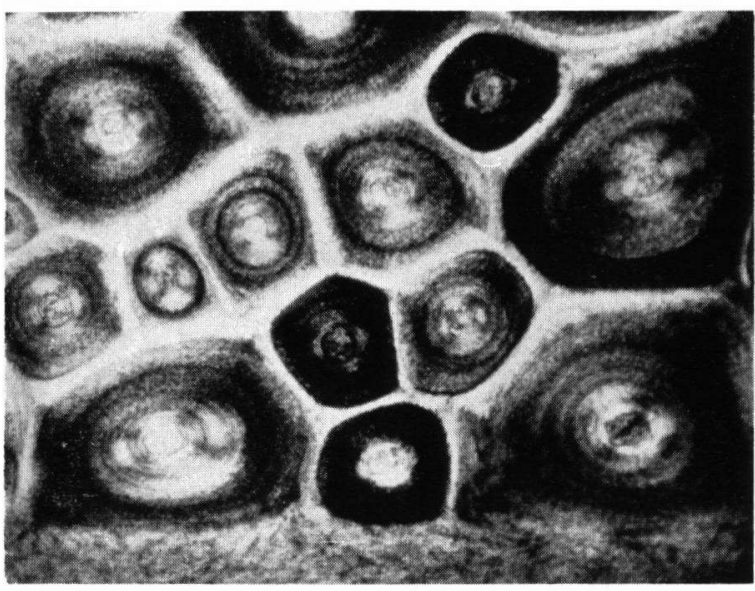

Fig. 28. Section of the free baleen plate perpendicular to the longitudinal axis of the horny tubes of the medulla of the plate, in polarized light. A part of the cortex is visible at the bottom of the picture.

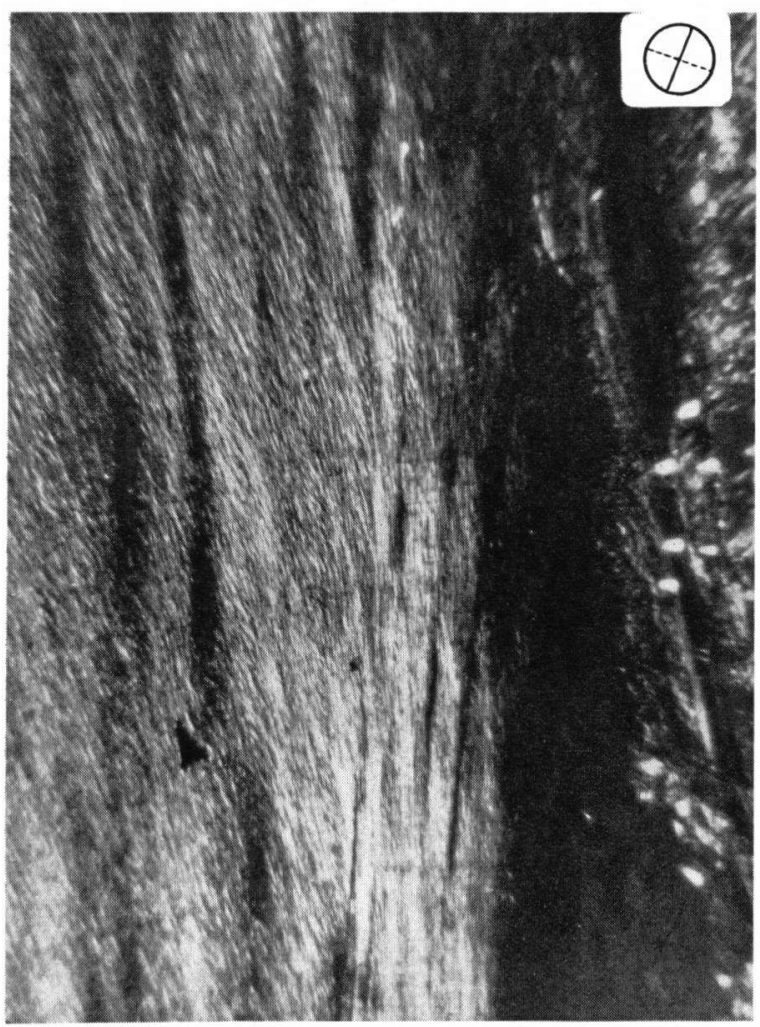

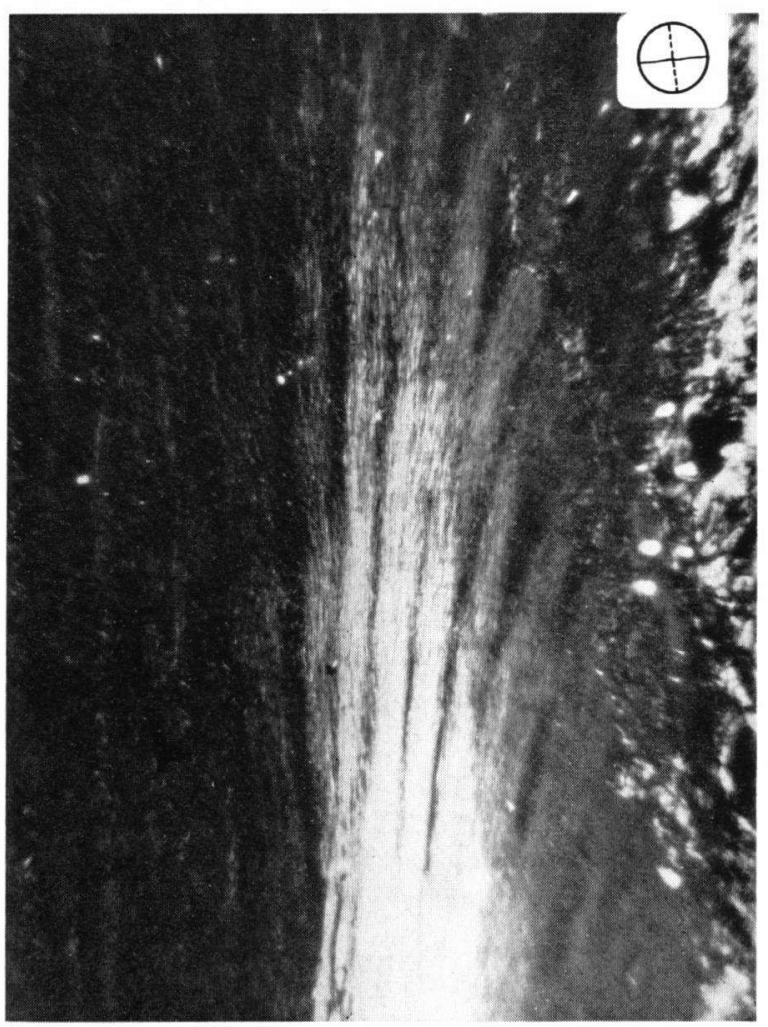

$b$

Fig. 29. Section parallel to the longitudinal axis of the baleen plate and perpendicular to its surface, through the "root" of the plate, examined in polarized light. The position of the polarizer (__ $)$ and analyser (- - - is indicated in the upper right corner. The rows of globular cells are visible as dark belts running parallel to the cortex, in the gum (a). However, these rows enter the cortex from the side of the epithelium covering the corium wall (b). $5 x$. 
cells in the darker staining part of the stratum spinosum adjacent to the cortex, shows a decline. From these measurements it appears that, in the animals of which the measurements are given in fig. 23 , curve $\mathrm{d}$, there is an initial increase in size of the cells of the stratum basale, just as is found in the stratum basale of the gum (curve $b$ in fig. 18). In the stratum basale of the epithelium that covers the corium wall this increase is from $10 \mu$ to $15 \mu$. In the stratum spinosum and the first few layers of the cortex a gradual decrease is found which becomes greater and greater.

\section{a. The stratum basale of the epithelium covering the corium wall}

The stratum basale of the epithelium that covers the corium wall, in the "root" of the baleen plate, is rather thin compared with the same stratum of the epithelium of the gum.

The longest axis of the cells of this stratum is not perpendicular to the dermo-epidermal border. This axis forms a small angle with it, in a section perpendicular to the surface of the corium wall and parallel to the longitudinal axis of the baleen plate. The nuclei of the cells of the stratum basale are oval like the cells themselves. The greatest length of the basal cells of the stratum basale is $16 \mu$ to $17 \mu$. This length is the same as that of the basal cells in the stratum basale of the gum.

The cells of the stratum basale of the epithelium that covers the corium wall have root-like radicles projecting towards the corium wall. They are circ. $8 \mu$ long. The same was described for the corresponding cells in the epithelium of the gum. These radicles are also filled with fine fibrils which fray out and form a brush-like mass (fig. 11). In the radicles spiral filaments are found (filaments of Herxheimer) just as in the cells of the stratum basale of the gum. The filaments of three or four layers of cells of the stratum basale run between the basal cells of this stratum into the dermo-epidermal border in the zone where the argyrophilic network is situated.

With the stain techniques applied, fibrillary structures appear to be dominant in the cells in the stratum basale of this epithelium. However, desmosomes and tonofibrils are not found here. In the dermoepidermal border the argyrophilic network shows the same characteristics as were described for this border of the epithelium of the gum.

\section{b. The stratum spinosum of the epithelium covering the corium wall}

The stratum spinosum of the epithelium that covers the corium wall in the "root" of the baleen plate is not well developed compared with the corresponding layer of the epithelium of the gum. The cells of this stratum lie close together, the intercellular spaces are small. This is contrary to what was found in the stratum spinosum of the gum. In the stratum spinosum of this epithelium tonofibrils, as found in the gum, are not present. In the cells only filaments are visible. These run in all directions. This is contrary to what was found in the stratum spinosum of the gum but corresponds with the fact mentioned on page 16 and the theory about the formation of tonofibrils. There are no indications of irregularities that give rise to bands of flattened cells and bundles of fibrils that can be compared with the tonofibrils. In this epithelium indications of forces are only found in the few layers of cells closest to the cortex. So it is reasonable to suppose that the transport of cells in this epithelium is so regular that development of forces which cause extra flattening of the cells during the growth, and also during fixing of the epithelium, is not possible. If cell transport had been irregular, a zone of flattened cells would have been found in the epithelium that covers the corium wall, just as in the stratum spinosum of the gum (see p. 13).

The colour of the cells in the stratum spinosum of the epithelium that covers the corium wall is less pronounced in the stained sections, just as in the stratum basale of the same epithelium. The nuclei are oval, while the diameter of the cells in the stratum spinosum in the direction of the growth of the cells is much greater than their width perpendicular to this direction. These cells are spindle-shaped. In this stratum compression causes a sharp but gradual increase in length of the cells, while in the same time the nuclei are compressed.

In a section parallel to the longitudinal axis of the corium wall and perpendicular to the surface of it, the distance between the desmosomes in the outline of the cells of the stratum spinosum is not constant. In some directions they are closer together than in other directions (fig. 24). The cells are encircled by a dark line, but in certain directions this line is only very faint. In one certain direction the row of desmosomes is very dark blue, in the sections stained with the Crossmon technique. This is particularly evident in the part of the stratum spinosum which is close to the cortex. Here no separate bodies of the desmosomes are visible in one direction in contrary to what is found in other directions, where they are visible as separate bodies.

These dark lines of desmosomes lie in a narrow clear zone between the contents of the cells of the 
stratum spinosum. In the layers of the cells of the cortex of the baleen plate (in the "root"), adjacent to the epithelium that covers the corium wall, the desmosomes are still visible, though cornification has already started (fig. 24). In the intercellular spaces of the stratum spinosum of the gum these differences in distance between the desmosomes in various directions are not clearly visible (figs. 16, 17). This crowding together of the desmosomes in the stratum spinosum of the epithelium that covers the corium wall may point to growth-pressure in a certain direction exerted on the cells in this epithelium. This direction forms a small angle with the dermo-epidermal border, and is the same as the direction of the longest axis of the cells in this epithelium.

The results of measurements taken of the cells of the stratum basale and stratum spinosum of the epithelium that covers the corium wall in the "root" of the baleen plate and also of the first few layers of the cortex, are given in a diagram in the same way as was done with the measurements of the cells in the epithelium of the gum (see p. 16).

The greatest diameter of the cells in the stratum basale forms a small angle with the dermo-epidermal border. In the stratum spinosum the greatest diameter has the same direction (fig. 22), from the dermoepidermal border to the cortex. The opening of this small angle is to the free end of the baleen plate. The rim of the corium lamellae and the corium papillae that penetrate the epithelium between the corium wall and the cortex also points in the same direction as the greatest diameter of the cells. The greatest diameter of the cells was measured just as the axis perpendicular to this.

Fig. 23 shows that the length of the greatest diameter of the cells in this epithelium (c) increases rapidly. Perpendicular to this direction there is an increment, after which a slight decrease appears in the first few layers of the stratum spinosum. This was also found in the stratum spinosum of the gum. There is a flattening of the cells in the higher layers of the stratum spinosum as they move further away from the dermo-epidermal border to the cortex of the baleen plate. However, as the length of the axis perpendicular to the longest axis is not much smaller in the cells of the stratum spinosum than in the cells of the stratum basale (figs. 22, 23), this means that the flattening of the cells in this direction is not very significant. The length of the cells measured in the direction in which the corium papillae run, i.e. the direction of their greatest diameter, shows a sharp increase in the stratum basale and stratum spinosum of this epithelium.
This length increases by leaps, just as in the gum (fig. 18). But in the epithelium that covers the corium wall these irregularities are much smaller than in the gum. However, the general trend of the curve representing the increase of the length of the cells is much steeper. In the stratum basale and particularly in the stratum spinosum the size of the cells increases.

Apparently this can only manifest itself as an increase in the length of the cells. Probably this is due to the fact that this epithelium is enclosed by the corium wall and the cortex of the baleen plate. Because of the increase in numbers of cells (cell divisions) and the increase in size of the cells there has to be constant movement of the entire system of the baleen plate and gum in the direction of the free end of the baleen plate. If this would not be the case it would result in compression of the cells in the epithelium that covers the corium wall. The main

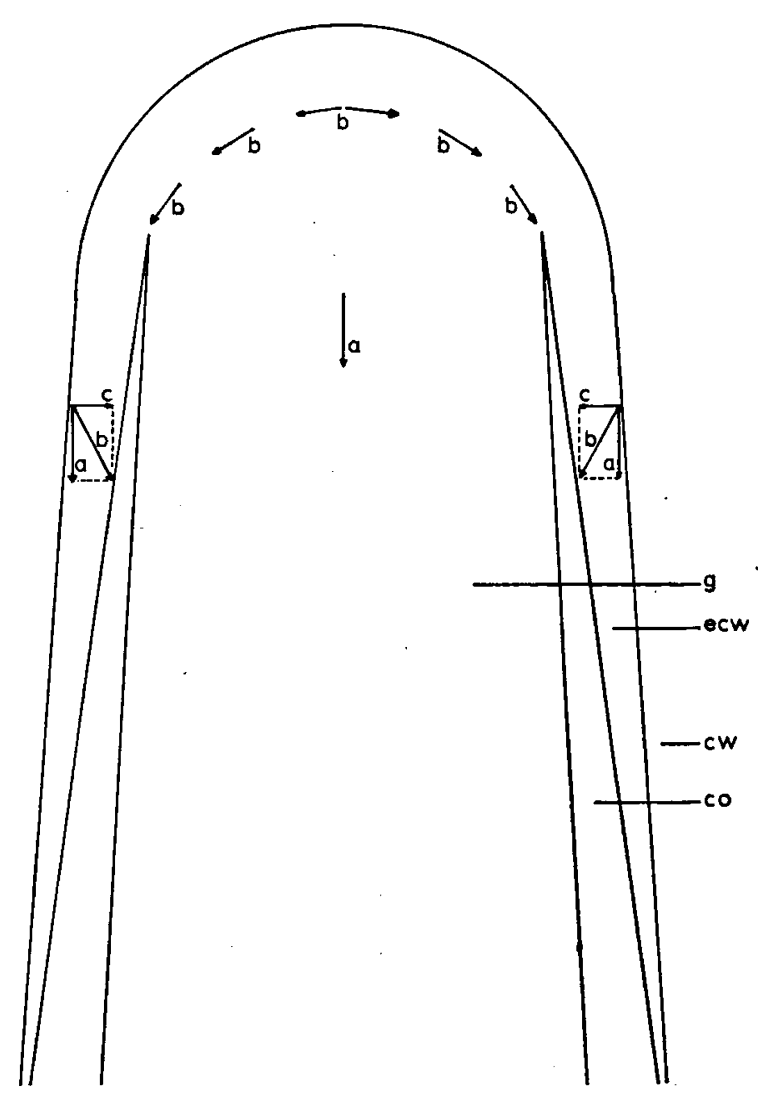

Fig. 25. Scheme of the "root" of a baleen plate (c.w. = corium wall; c.o. = cortex; $\mathrm{g} .=$ gum). The arrows $a$. indicate the general direction of growth of the whole complex of gum and baleen plate. The arrows $b$. indicate the direction in which the longest axis of the cells of the epithelium increases. The arrows $c$. indicate the addition of cells to the inner side of the cortex. 
direction of the movement of the cells in the epithelium that covers the corium wall, is the same as the direction of the growth in length of the whole system of baleen plate and gum ( $a$ in fig. 25).

From what was said above it will be evident that in this epithelium there is also a movement of the cells from the dermo-epidermal border to the cortex of the baleen plate, since they pass into this cornified layer. The direction of this movement is indicated by the longest axis of the cells and by the direction in which the corium papillae and the rows of globular cells, formed on the tops of them, run (b in fig. 25). These globular cells all disappear into the cortex. Also the accumulation of the desmosomes as to form dark blue lines between the cells is in this direction (figs. 22, 24). A third direction of movement of the cells in the epithelium that covers the corium wall, perpendicular to the main direction of growth of the whole system of baleen plate and gum, is the movement of the cells to the cortex ( $\mathrm{c}$ in fig. 25). All these movements are caused by the increase of the numbers of cells by cell division in the stratum basale and stratum spinosum of this epithelium.

\section{c. The cortex in the "root" of the baleen plate}

In the cornified cortex, in the "root" of the baleen plate adjacent to the epithelium that covers the corium wall, the outlines of the cells are recognizable as clear belts which are very weakly stained and which encircle the intensively stained and heavily compressed cell contents. In these clear belts a fine blue line of desmosomes is visible. These are packed together. This is the same situation as is found in the epithelium between the corium wall and the cortex. The nuclei in the flattened cells of the cortex, adjacent to the epithelium covering the corium wall, are visible as dark, almost black bands in the intensively stained cell contents (figs. 24, 26).

There is a stratification in the cortex, in the unstained microscopic sections as well as in the stained ones (figs. 6, 7, 23). The part of the cortex adjacent to the gum consists of very heavily compressed cells. This part is dark in stained and unstained sections. This layer, however, is rather thin compared with the part of the cortex adjacent to the epithelium that covers the corium wall. The latter is more transparent in the unstained sections and shows bright colours in the stained ones.

The series of bands of flattened cells which form the arched "fibres" in the gum, in the "root" of the baleen plate, only form the heavily compressed dark superficial layer of the cortex (figs. 7, 8, 26). This is clearly demonstrated by the fact that these bands run from the gum into the cortex. Therefore a superficial layer is torn off when pieces of gum are removed from the cortex.

In both epithelia, the gum and the epithelium that covers the corium wall, the longest axis of the cells forms a small angle with the longitudinal axis of the baleen plate. In the epithelium that covers the corium wall, the cells formed on the tops of the corium papillae, also run in this direction. They pass into the inner zone of the cortex, where they are still recognizable for a short distance (figs. 7, 8). At last they become flattened. This is contrary to what was found in the gum, where these rows of round cells all run parallel to the entire length of the surface of the cortex. Only a few of these rows, which enter the area where the tip of the outer layer of the cortex is formed, run into the cortex and become totally flattened. The ultimate thickness of the two layers of the cortex is different. The newly formed cortex at the "base" of the "root" of the baleen plate only consists of the few heavily compressed dark layers of cells originating from the gum. The epithelium that covers the corium wall has its greatest thickness in this area (figs. 5, 6, 7, 8). The thickness of this epithelium decreases in the same degree as the cortex increases in thickness, in the direction of the rim of the corium wall. This increment in thickness of the main part of the cortex is caused only by addition of material to its inner side by the epithelium that covers the corium wall. At the place where the epi. thelium disappears at last, at the point where the rim of the corium wall passes into the long threadlike papillae, the cortex has reached its ultimate thickness. Then no further increment in thickness of the cortex is possible. The increase of the total thickness of the cortex is regular and takes place over a long stretch.

The superficial layers of the cortex, adjacent to the gum, vary considerably in thickness. At irregular intervals thickenings are present in this layer. They are opposite to each other in the cortex on both sides of the baleen plate. These thickenings occur with the same intervals and at about the same height in the cortex of the other baleen plates of the whole set of one animal (see also Ruwn, 1940, 1945).

It is impossible to give exact figures for the thickness of the different layers which form the cortex of the baleen plate. This is owing to the great variations in thickness along the whole length of this part in the "root", embedded in the gum, and also of the other components.

On the average the total thickness of the cortex of 
a baleen plate is maximum $3 \mathrm{~mm}$. This is also the thickness of the epithelium that covers the corium wall in the zone where the first outer layers of the cortex are formed by the gum. Together these outer layers are circ. $100 \mu$ to $300 \mu$ thick. This variation is mainly due to differences in height of the thickenings.

When fig. 7 and fig. 8 are compared it is obvious that the thickness of the outer layers of the cortex, adjacent to the gum, depends on the amount of material added to it by the gum. In fig. 8 a great mass of bundles of "fibres" run into the cortex, in the area where these outer layers are formed. This part is thick in comparison with the corresponding part shown in fig. 7, from another animal. From fig. 18 it is evident that the thickness of the cells in the stratum spinosum of the gum that form these "fibres", measured in a direction perpendicular to their longest axis, shows only very small variations. So it is obvious that there must be a correlation between the width of these bundles of "fibres" and the numbers of cells in these bundles on the one hand, and the thickness of the outer layer of the cortex, into which such a bundle or group of bundles ends, on the other hand.

\section{FORMATION OF TONOFIBRILS}

From what was said above (page 16 and 21) of the stratum spinosum of the gum and of the stratum spinosum of the epithelium that covers the corium wall in the Fin Whale and the Blue Whale, it is evident that there always are desmosomes in the walls of the cells. Tonofibrils are found in most cells of the stratum spinosum except in the cells formed by the stratum basale on the tops of the corium papillae, formed beyond the line where flattening of the cells of the stratum spinosum occurs (fig. 19). Neither are there tonofibrils found in the cells of the stratum spinosum of the epithelium that covers the corium wall (figs. 22, 24).

In these cells and in the cells formed on the tops of the corium papillae there are only fine, wavy filaments. These run in all directions through the cells and show no clear connections with the desmosomes, which are visible as dark thickenings in the cell membrane. It is evident that the reality of the tonofibrils in the stratum spinosum is questionable, as in both cases in which they are not found in the cells, these cells were not subject to heavy forces exerted on them. Moreover, they are easily reached by the fixing fluid. On the contrary, the cells of the stratum spinosum of the gum are subject to heavy pressure, while penetration of the fixing fluid may be very difficult and slow.
So the value of different structures in stained microscopic sections of epidermal tissue is questionable. This is obvious for the tonofibrils, and it is very clear in the cells formed on or close to the tops of the corium papillae. It is reasonable to suppose that the fixing fluid easily penetrates the gum via the corium papillae, while penetration is more difficult through the dense epithelium of the gum. In the papillae the connective tissue fibres and blood vessels run in a longitudinal direction, along which the fixing fluid may penetrate deeply into the epithelium. In this way the epithelial cells near the tops of the corium papillae are reached very quickly by the fixing fluid. From here the fluid penetrates the epithelium rather slow. Consequently there may be a gradation in the quality of the fixation, dependent on the distance of the cells to the tops of the corium papillae (fig. 20). From what was said on page 18, however, it is evident that these cells are not subject to compressing forces. Actually, in the cells near or on the tops of the corium papillae in the gum no tonofibrils or only very faint indications of fibrils are visible. Although indications of the formation of "prickles" are present (fig. 20).

On the side of the cell bordering the top of the corium papilla no "prickles" are present. Along the sides where the cell is bordered by adjacent cells of the stratum spinosum of the gum the "prickles" become better developed, when the distance to the papillae or to the point where the fixing fluid enters the cell increases (fig. 20). On the side of the cell, opposite to the side where it borders the corium papilla, there are distinct "prickles". However, they are small compared with those of the cells deep in the stratum spinosum of the gum (fig. 16). The ends of the "prickles" are formed by the dark desmosomes in the cell membrane. In the "prickles" short tufts of fibrils are found. These occur only in the longer ones. The shorter the "prickles" are, the less the tufts of fibrils become distinguishable. They are not visible in the smallest ones.

It is evident that the cells of the stratum spinosum of the gum are connected with each other at certain points. These points are the desmosomes. When the walls of two adjacent cells are separated, by shrinkage of the cells under the influence of the fixing fluid, the desmosomes become more and more distinct as this shrinkage continues and the threadlike extensions of the cells become longer. This is particularly clear in the cells on the tops of the corium papillae. Shrinkage of the cells in an epithelium may give rise to the development of intercellular spaces crossed by "prickles" where the cells keep contact 
with each other in the desmosomes. In the epithelium that covers the corium wall a similar situation, as is found for the cells on the tops of the corium papillae in the gum, exists. This comparatively thin epithelium lines the corium wall, which can to some extent be compared with the corium papillae. All cells in this epithelium are easily reached by the fixing fluid, while there are also no indications pointing to variations in the forces working on this epithelium. As was said before in this epithelium no tonofibrils are found, while desmosomes are clearly visible. The cells are full of a felt-like mass of filaments. In the cornifying cells formed by the epithelium covering the corium wall, however, coarser fibrils are present.

In literature the following opinions are expressed concerning the presence and reality of tonofibrils in the cells of the stratum spinosum of epidermal tissue:

a. Desmosomes and tonofibrils form a system which is constantly present in the cells. The fibrils form a more or less rigid system. This opinion is clearly expressed by, for instance, SALECKer (1943) and Charles and Smiddy (1957).

b. Tonofibrils are formed under the influence of fixation, while fixing of the tissue with fluids that contain osmic acid or acetic acid results in a lower number of tonofibrils visible in the sections. Mechanical stimulation also causes sweiling or shrinkage of the cells (DE Moulin, 1923; Chambers and Rényi, 1925; Lewis, Pomerat and Ezell, 1949; FawCETt, 1958; Martinotti, 1921; HoEPKE, 1927: quoted after HonstManN, 1957).

Burgos and WisLocky (1956) found that the distance between the cells of the stratum spinosum in the vaginal epithelium of the Guinea Pig was small during dioestrus. There was a great distance between these cells during the oestrus period, when "prickles" were present.

The functional aspect of the epithelium and the need of nutritients in the epithelium may cause shrinkage of the cells. In this way the intercellular spaces become considerably larger. This promotes the supply of nutritients and can cause the formation of "prickles", while the cells maintain mutual contact at the desmosomes.

From the results of various electron microscopic examinations of the epidermis, in particular of its stratum spinosum, it appears that desmosomes are always present. If tonofibrils are present, they are found in various stages of development (SELBY, 1957;
FaWCETT, 1958; HohstManN and KNOOP, 1958; ZWILlenBerG, 1959).

The development of the "prickles" and tonofibrils in the stratum spinosum of the gum probably depends on the functional aspect of the epithelium, while forces acting on the tissue and the quality of the fixation are highly important factors in the formation of these structures.

What probably happens during shrinkage of the cells is demonstrated in the schemes I, II and III (fig. 27).

Scheme I represents the ideal situation as shown in a number of electron-microphotographs (HonsTMANN and KNOOP, 1958; HaY, 1961; ZWILlenberG,
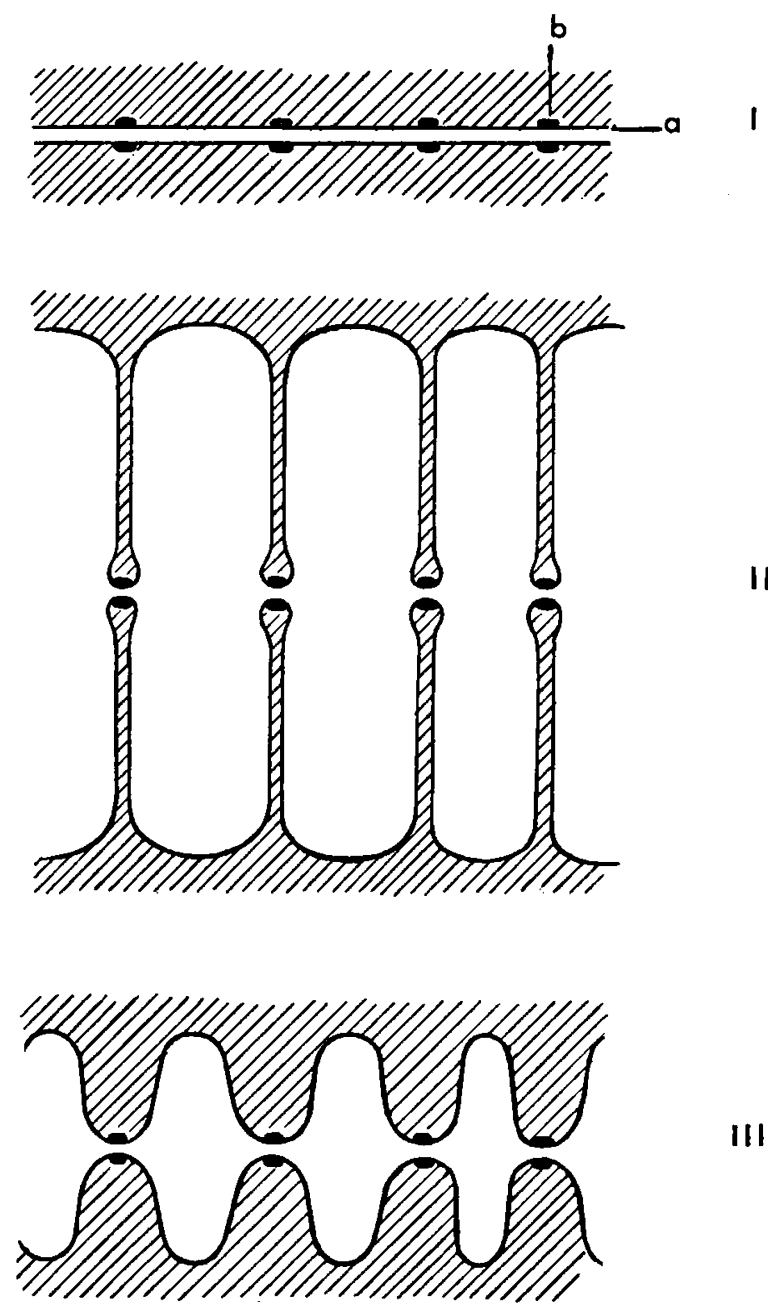

III

Fig. 27. Scheme of the development of the prickles. a. cell membrane; $b$. desmosome.

I. normal situation of parallel cell membranes.

II. situation mostly present in microscopic sections.

III. intermediate stage dependent on the quality of fixing and also of the activity of the cells. 
1959). The cell membranes of two cells are parallel to each other. Desmosomes are opposite to each other as thickenings of the cell membrane. Scheme III gives the situation that is normally seen in the stratum spinosum. The tonofibrils or "prickles" are well developed, as the intercellular space between the walls of two adjacent cells is large. Scheme II shows a transitional stage between I and III. In scheme I and II the situation is as was described for the cells on or near the tops of the corium papillae.

Fixation of tissues also causes shrinkage of the cells. As was described before, in the cells on the tops of the corium papillae only very fine fibrils are present in the plasma and no "prickles" or only very small ones occur. The cells maintain their mutual contact by means of the desmosomes, which are opposite to each other with a constant distance in between. Originally the membranes of both cells were parallel to each other (scheme I).

When shrinkage of the cell starts, the distance between the membranes becomes larger, while the desmosomes of two neighbouring cells remain opposite to each other and at the same distance. This gives rise to small "prickles" as seen in the cell in fig. 20 and scheme II. The "prickles" end in a small dark desmosome, and are filled with plasma.

It is evident from what was seen in the cells on the tops of the corium papillae in the gum that there is a correlation between the development of the "prickles" and the distance of these cells to the top of the papilla, where the fixing fluid first enters the cell. When the cell further decreases in size, the "prickles" become thin, long, threadlike and pronounced structures, which end in a knob formed by the desmosome. The part of the cell membrane between two desmosomes is now retracted close to the nucleus of the cell and the cell contents are coarsened, also in the "prickles" (scheme III). Forces in a growing epithelium (see also FAwCETT, 1958) and also shrinkage during fixing of such an epithelium, may promote the formation of tonofibrils.

Fixation may be considered as condensation and precipitation of the cell contents,- especially of the chains of albuminous macro-molecules of the cell plasma. When this happens, and when the cells decrease in size and become deformed, the macromolecules may be bundled and pressed together. This will cause a coarsening of the structures in the cells to a degree at which they become visible with the light microscope (see also Medawar, 1953). This will particularly occur in the "prickles" of the cells, and gives rise to the formation of coarse fibrils. These are composed of bundles of macro-molecules pressed together by the wall of the cell, and form the tonofibrils. In the microscopic slides these are predominating coarse structures in the stratum spinosum of the epithelium of the gum in the Fin Whale and the Blue Whale. The formation of the "prickles" or tonofibrils is caused by shrinkage and condensation of the macro-molecular contents of the cells of the stratum spinosum. These cells decrease in size while the intercellular space increases. The cells keep mutual contact by means of the desmosomes in the cell membrane.

Results of the examination of the epithelium of the gum and of the epithelium that covers the corium wall in the Fin Whale and the Blue Whale, give clear indications that the desmosomes are always present in the walls of the cells of the stratum spinosum, whereas tonofibrils are only present when forces are working in the epithelium. They are formed due to the presence of the desmosomes, which is in accordance with the observations of Chapman and Dawson (1961) who mention the tendency of fibrils to concentrate in the points of attachment of the cells in the Anuran epidermis.

E. EXAMINATION OF THE "ROOT" OF THE BALEEN PLATE AND THE FREE BALEEN PLATE IN POLARIZED LIGHT

The tubes in the medulla are easy to distinguish in thin sections of the free baleen plate, in which the plane of the section is perpendicular to the longitudinal axis of the tubes. When examined in polarized light they show an uni-axial interference figure, similar to that of an uni-axial crystal. The optical axis of these tubes coincides with their longitudinal axis (fig. 23). In a section, parallel to the longitudinal axis, there is no interference figure. There is, however, a very distinct difference in colour and intensity between the various layers that form the wall of the tubes, varying from bright red to orange, dark red in all shades and bright green. This is also visible in the sections perpendicular to the longitudinal axis, but less pronounced. These differences in colour and intensity are caused by differences in orientation of the cornified cells, to the plane of the section and of polarization in the layers that form the wall of the tubes. In the microscopic sections, perpendicular to the longitudinal axis of the tubes, concentric layers in the wall of the tubes are visible (figs. 4, 28). This difference in direction causes the various colours in polarized light and points to a spiral arrangement, different in the successive layers. NiCKEL (1938) has given a diagram of the horny tubes in the wall of the hoof of the horse. It shows that these tubes are 
formed by a number of layers of cornified cells. These cells are arranged in spirals around the lumen of the tube. In the successive layers the spirals alternate to right and left, and are more or less steep. This agrees with the situation in the horny tubes in the medulla of the baleen plate.

In a section through the "root" of the baleen plate, parallel to the longitudinal axis and perpendicular to its surface (figs. 7,8 ), the fibres of the connective tissue of the corium wall, the corium lamellae and papillae, and the cortex of the baleen plate show a distinct birefringence. There is also some birefringence in the epithelium that covers the corium wall and also in the gum. In a section perpendicular to the longitudinal axis of the baleen plate, there is no birefringence at all in this epithelium.

In a section parallel to the longitudinal axis and perpendicular to the surface of the cortex of the baleen plate, the fibres in the corium wall, the fibrillary material in the epithelium between the corium wall and the cortex and the fibrillary structures in the gum, all run parallel to this plane of the section.

Birefringence is very clear in the gum. In a section through the "root" of the baleen plate, perpendicular to its longitudinal axis, there is an alternation of dark and light bands in the gum. In polarized light these dark bands and the cortex of the baleen plate show clear birefringence. The distance between the birefringent bands in the gum is not constant. Close to the cortex these bands are close together, the distance between them rapidly increases with increasing distance to the cortex. These birefringent bands are the same as the darker staining arched bands of heavily flattened cells that run from one baleen plate to the next.

In a section through the "root" of the baleen plate parallel to its longitudinal axis and perpendicular to its surface, there is a strong birefringence of these bands in the gurn. From this it is evident that the "fibres" in these bundles have the same direction as the plane of the section has. The fibrillary material in the cells has the same direction. This is also the direction of the plane of the longest axis of the cells of the stratum spinosum in the gum. However, the parts of the gum between these highly birefringent bundles show a weaker birefringence. This points to a relation between the degree of flattening of the cells and their orientation. This is in agreement with the results of histological and cytological analysis.

In the plane of section mentioned above the fibrous structures in the gum show maximum birefringence if the polarizer and analyser are turned in a position as indicated in fig. 28. From this figure it is evident that the "fibres" in the gum run in an arch to the cortex and pass into this layer. There is, however, no birefringence in the epithelium between the corium wall and the cortex. But if the nicols are turned about $60^{\circ}$ there is maximum birefringence in the epithelium between the corium wall and the cortex and extinction in the gum (fig. 28). From both figures it is evident that fibrous structures run from both sides to the cortex, from the gum as well as from the epithelium between the corium wall and the cortex. Therefore it is evident that material is added to the cortex from both sides. From fig. 28 it is also evident that the cells formed on the tops of the corium papillae in the gum are not birefringent. They are seen as dark bands in the sections examined in polarized light and their course is independent of the direction of the bundles of "fibres". The fact that these cells are not birefringent at all also points to the connection between the flattening of the cells and the formation and orientation of fibrous material in these cells. In the epithelium between the corium wall and the cortex the dark bands of cells formed on the tops of the corium papillae that originate from the corium lamellae of the corium wall, run in the same direction as the longitudinal axis of the cells in this epithelium (figs. 7, 8, 28). At last they disappear as they become flattened in the cornified cortex. There they have the same optical characteristics as the surrounding cells of the cortex which originate from the normal stratum basale.

From the examination in polarized light the conclusion is also drawn that material is added to the cortex of the "root" of the baleen plate, from the epithelium between the corium wall and the cortex as well as from the epithelium of the gum. These facts confirm the findings of other histological and cytological examinations.

\section{CHAPTER III}

\section{Conclusions}

The "root" of the baleen plate consists of the following parts: a. the corium wall, and at its rim the long hairlike papillae on which the horny tubes of the medulla of the baleen plates are formed. From the sides of the corium wall lamellae penetrate the adja- 
cent epithelium. These lamellae turn into papillae;

b. the epithelium that covers the corium wall. This epithelium is situated between this wall and the cortex;

c. the cortex which is already cornified in the "root" of the baleen plate. The cortex consists of two parts, one part formed by the epithelium that covers the corium wall and the other part formed by the gum;

d. the gum, situated between two adjacent baleen plates.

The borderline of the corium and the gum is arched.

The epithelium of the gum and the epithelium that covers the corium wall are both cutaneous epithelia. They consist of a stratum basale and a stratum spinosum. There is no stratum granulosum or stratum lucidum. The cortex of the baleen plate can be considered as a stratum corneum. From cells of the stratum basale of both epithelia radicles run into the argyrophilic network of the corium. These radicles and the cells are full of fine fibrillary structures. These cannot be compared with the tonofibrils of the cells in the stratum spinosum. There are no indications of a connection between the fibrillary structures of the stratum basale and those of the stratum spinosum. A great difference between the two epithelia is that no tonofibrils are visible in the epithelium that covers the corium wall, whereas in the stratum spinosum of the gum the system of tonofibrils is highly developed.

This can be explained by assuming that the amount of cells formed (in a certain period) in the epithelium that covers the corium wall is in accordance with the total growth in length of the baleen plate and with the increase in thickness of its cortex in the "root" of the plate. So no pressure can be build up in this epithelium. As was shown on page 18, this pressure is exerted in the epithelium of the gum, and consequently tonofibrils are present in that epithelium.

In the epithelium between the corium wall and the cortex, the longest axis of the cells of the stratum spinosum forms a small angle with the dermoepidermal border. The direction of this axis is towards the inner side of the cortex just as the direction of the corium papillae that penetrate this epithelium from the side of the corium wall. This direction of the longest axis is such that there is a movement of cells in the epithelium that covers the corium wall, to the inner side of the cortex and also in the direction of the growth in length of the baleen plate. The movement of the cells in the epithelium that covers the corium wall is in the direction of the cor- tex and gives rise to the increment in thickness (figs. $22,24)$ of this cornified layer.

The nearer the cells in the epithelium that covers the corium wall come to the cortex, the more flattened they become. This is a very regular process for no bands of flattened cells are found. Also in the curve (figs. 22, 23), representing the increase in length of the longest axis of the cells in this epithelium, high peaks are absent. This is contrary to what is seen in a similar curve of the cells of the gum (figs. 7, 8, 18). As was already mentioned above, only filaments are present in the cells of the stratum spinosum of the epithelium that covers the corium wall but no tonofibrils. However, desmosomes present in the direction of the longest axis of the cells, are crowded together, which is not the case with desmosomes present in other directions. They form fine dark lines. The absence of tonofibrils is an indication that the cells are not subject to heavy and variable compression. It also points to a regular transport of the cells. The corium papillae penetrating the epithelium that covers the corium wall and the epithelium of the gum are covered by the stratum basale. On the top of each papilla a single row of spherical cells is formed. Flattening of these cells does not occur, not even in the stratum spinosum of the gum and in the epithelium that covers the corium wall. This is due to the fact that they are formed beyond the zone where flattening of the cells of the stratum spinosum occurs. In the epithelium that covers the corium wall, the corium papillae have the same direction as that in which the longest axis of the cells of the stratum spinosum points. They form a small angle with the dermoepidermal border in the direction of the cortex. This is also the case with the rows of spherical cells formed on the tops of the corium papillae. As soon as they enter the inner layer of the cortex they can not be distinguished from the surrounding material. All this points to a growth in the epithelium between the corium wall and the cortex, which is about equal to the growth in length of the baleen plate. If this had not been the case, signs of extra flattening would have been present. On the other hand the rows of spherical cells formed on the tops of the corium papillae in the gum all run parallel to each other and to the outer layer of the cortex. They never enter the cortex. Birefringence in the epithelium that covers the corium wall is due to the flattening of the cells, by which the contents of these cells are forced to take the direction of the longest axis of the cells. This is proved by the fact that the cells formed on the tops of the corium papillae, which are not flattened, show no birefringence. However, they be- 
come birefringent when they enter the cortex where they are at last flattened.

All the above mentioned facts show that the cells in the epithelium that covers the corium wall move in the direction of the cortex. This is also confirmed by the data obtained from analysis of the epithelium that covers the corium wall in polarized light. The rows of cells, formed on the tops of the corium papillae, are not found in all layers of the cortex. They are absent in the outer layers adjacent to the gum. This is an indication for the fact that only a part of the cortex is formed by layers of cell material from the epithelium that covers the corium wall.

The dermo-epidermal border of the gum is arched. From the dermis long corium papillae penetrate the epithelium. The cells of the stratum basale of this epithelium show the same characteristics as the cells of the corresponding layer of the epithelium that covers the corium wall. In the stratum spinosum of the gum, however, the development of the system of tonofibrils is striking. It is also evident that the cells in this stratum become flattened as the distance to the dermo-epidermal border increases. In the centre of the arch of the dermo-epidermal border, at a distance of circ. $2 \mathrm{~mm}$ from this border, there is in the stratum spinosum a band of darker staining cells which is also arched. This arch of darker staining cells is not always clear in sections of the gum of different individuals of Fin Whales and Blue Whales. But if present, this arch always is at the above mentioned distance from the dermo-epidermal border. At irregular intervals to each other these darker bands are also seen in the more superficial layers of the stratum spinosum of the gum. They all end on both sides of the baleen plate in the cortex.

At the base of the stratum spinosum the longest axis of the cells is about perpendicular to the dermoepidermal border. Its direction gradually changes and finally the axis is parallel to the dermo-epidermal border. This change of direction of the axis is coupled with an increase in length. The cells reach their greatest length in the dark bands. The cells are heavily flattened here. Their nuclei are all visible as bands and the tonofibrils are pressed together forming coarse fibres. This is different from what is found in the cells of the stratum spinosum of the gum outside these dark bands. All dark bands present in the gum end in the thickenings of the cortex. The first band ends on both sides in the origin of the cortex. At first tonofibrils in the cells of the stratum spinosum of the gum run in all directions through the cells. In the bands of dark cells, however, all tonofibrils run in a direction parallel to the longest axis of the cells.
Consequently they are also directed to the cortex. In the centre of the arched bands in the stratum spinosum staining of the cells is less intensive than on both ends. The cells are less flattened, the tonofibrils are visible as separate fibres. The longest axis of the cells is somewhat shorter than it is in the cells in the other parts of the arch. From this it is evident that compression of the cells is comparatively weak in the centre of the arch and strongest in both ends, close to the cortex.

The corium papillae in the gum reach beyond the first arch of flattened cells. On the tops of these papillae rows of spherical cells are formed. They never become flattened in the more superficial layers of this epithelium, as they are formed beyond the zone where the cells of the stratum spinosum become flattened. These rows of round cells run parallel to each other and to the surface of the cortex. These cells can even be recognized at the surface of the gum as spherical cells. Corium papillae are also present in the stratum spinosum of the gum, at the base of the corium wall (figs. 7,8 ). Here the outer layer of the cortex of the baleen plate is formed by cornifying cells originating from the gum. On the tops of these papillae also rows of spherical cells are formed. A few of these rows run into the heavily flattened part of the arched band and are bent in the direction of the longest axis of the cells in this band. Only these rows of spherical cells become flattened as they run into the outer layer of the cortex. These are the only rows of spherical cells in the gum which run into the cortex and become flattened.

From the above mentioned facts it is evident that flattening of the cells only occurs in an arched zone in the stratum spinosum of the gum. In the centre this arch is at circ. $2 \mathrm{~mm}$ distance from the dermoepidermal border. At both ends of this arched zone the cells of the gum become totally flattened and form the outer layer of the cortex. If there would also be flattening of the cells of the stratum spinosum of the gum in the more superficial layers, the spherical cells originating from the tops of the corium papillae would become flattened also in other parts than the above mentioned. Those closest to the cortex, already formed, would then run into this layer and become totally flattened. This, however, is never found. So it is evident that material is not added from the gum to the cortex along its whole length, but only near the base of the corium wall. The further increase in thickness of the cortical layer of the baleen plate is caused by the addition of material from the epithelium that covers the corium wall to the outer layer already present. 
From all the facts mentioned above it is evident that the cortex of the baleen plate consists of two layers:

a. the outer layer which is formed by the gum, but only in the zone at the end of the first arched bundle of heavily flattened cells, and

b. the thick inner layer which is formed by the epithelium that covers the corium wall. Addition of the cells to the cortex by this epithelium is along the whole length of its inner side.

This is contrary to what was assumed by Ruov (1940, 1945), who is of the opinion that the growth in thickness of the cortical layer of a baleen plate is solely due to the addition of material by the epithelium that covers the corium wall.

The tonofibrils are most probably an indication of pressure in the tissue, caused by growth and subsequent shrinkage. They are only found in those cells of the stratum spinosum which are more or less flattened. They are not found in the round epidermal cells formed on the tops of the corium papillae, nor in the epithelium that covers the corium wall. It is reasonable to suppose that the pressure works in a direction perpendicular to the dermo-epidermal border, at least in the deeper layers of the gum, and parallel to the longitudinal axis of the baleen plate. This is the direction in which the baleen plate increases in length. The longest axis of the cells of the stratum spinosum of the gum is perpendicular to this direction, so it is reasonable to assume that these cells are flattened by this pressure. In the centre of the gum halfway between two baleen plates, the cells are less flattened than in other parts of the gum. Flattening increases from the centre of the gum to the base of the corium wall. Owing to the arched form of the dermo-epidermal border there are more cells present in an area outside the centre of the arch than in an area of the same size in the central part. This means that there is a higher number of cells in the stratum basale and stratum spinosum of the part first mentioned that can divide, so that the pressure on the more superficial cells is stronger here. Together with the convergent movement of the cells of the stratum basale and stratum spinosum of the gum, the cells are flattened and spread sideways.

At the base of the corium wall cells meet from two sides, the cells of the epithelium that covers the corium wall and the cells of the stratum spinosum of the gum which are already more or less flattened. The latter will become subject to still more pressure and form the outer layer of the cortex. This is the only part of the cortex present in this area.
The epithelium that covers the corium wall and the epithelium of the gum are both cutaneous epithelia. Both react in the same way to a stimulation or inhibition of the mitotic activity of the cells in the stratum basale and the stratum spinosum. However, owing to the arched form of the borderline between the corium and the epithelium of the gum, there is a higher number of cells in this epithelium. Moreover, owing to the greater total thickness of the stratum basale and stratum spinosum, there are more cells which can divide. When the mitotic activity increases under the influence of a certain stimulus, e.g. hormones produced in the period of ovulation (Bullough, H. F., 1943, 1947; Bullough, W. S., 1946, 1949, 1962), this increase is equal in both epithelia. In the epithelium of the gum, however, more cells are able to divide than in the epithelium covering the corium wall. This causes the increase in pressure in the epithelium of the gum, and consequently gives rise to a broad band of flattened cells in the stratum spinosum of the gum. More cells are then pressed together at the end of the band near the corium wall which causes a greater thickness of the outer layer of the cortex. When the mitotic activity decreases again to a lower and constant level, the thickness of the outer layer also decreases. Consequently at the moment of highest mitotic activity, the greatest thickening of the cortex is caused, and at the lowest mitotic activity the smallest thickening.

In the stratum basale and stratum spinosum of the epithelium that covers the corium wall, the same stimulus results in a smaller number of cell divisions, as compared with the number of cell divisions possible in the stratum basale and stratum spinosum of the gum. It is evident that pressure is built up and is greatest on the superficial cells of the stratum spinosum of the gum. This causes extra flattening of these cells, while the speed of the outward growth of the whole complex of gum and baleen plate also increases. In the epithelium that covers the corium wall the increase in number of cells is probably so much smaller that this keeps pace with the increase in the speed of growth of the whole complex of gum and baleen plate. If this would not be the case there would also have been extra flattening of the cells in the stratum spinosum of the epithelium that covers the corium wall.

It is evident that the speed of growth in both epithelia is equal in the direction of the longitudinal axis of the baleen plate, for otherwise parts of the gum or the epithelium that covers the corium wall would be torn off. The longest axis of the cells in the epithelium that covers the corium wall is directed 
obliquely to the inner side of the cortex, in the direction of growth of the whole system. In this way the cells can move from the corium wall to the cortex. In the gum the longest axis of the greater part of the cells is perpendicular to the general direction of growth, except in the area near the base of the corium wall. Here, however, the cells are pressed sideways by the other cells in the epithelium that are nearer to the middle of the gum, when these cells become flattened. From the fact that no extra flattening of cells is found in the epithelium that covers the corium wall and from the direction of cell transport, it is evident that this epithelium acts as a layer by which the cortex slides from the corium wall, by means of addition of cells to the cortex. As the epithelium of the gum is much greater in size than the epithelium that covers the corium wall, a rise in the mitotic level will cause a higher outward pressure on the epithelium of the gum. The speed of growth in this epithelium evidently is equal to the speed of growth in the epithelium that covers the corium wall. Because of the higher outward pressure a greater number of cells is pressed sideways at the same time. This causes a wider band of flattened cells and consequently a greater thickness of the outer layer of the cortex.

Variations in the activity of e.g. the ovaries, by means of hormonal activity cause variations of the mitotic activity in the epithelium and in this way in the cornification; cornifying material is added to the outer surface of the cortex by the epithelium of the gum, as well as to the inner surface of the cortex by the epithelium that covers the corium wall. The variations in cornification on the outer surface occur in one spot and are visible as peaks and hollows. Addition of cornifying material to the inner surface of the cortex is gradual and along the entire length so that the variations cannot demonstrate as peaks and hollows.

As was said above the cortex of the baleen plate is formed by two epithelia, both of epidermal origin. Far the greater part of the cortex is formed by the epithelium that covers the corium wall. Only a small and variable number of layers, which form the surface of the baleen plate, are added by the gum. This is contrary to Ruon's opinion. He assumes that the cortex of a baleen plate is only formed by the epithelium that covers the corium wall. If this would be the case sudden sharp variations in thickness would not be present on the outer surface of the cortex. This is contrary to what can be seen on the outer surface of a baleen plate and in the record of such a plate. On the other hand no bands of flattened cells are ever found in the epithelium that covers the corium wall, even though there is a very highly developed first band of flattened cells in the stratum spinosum of the gum (figs. 7, 8, 17).

The long range increment in thickness of the baleen plate, and consequently also of the cortex is certainly a result of the addition of material to the cortex by the epithelium that covers the corium wall. The variations in thickness of the baleen plate, the peaks and hollows, are caused by the addition of material from the gum to the cortex. Obviously the occasionally occurring "jumps" in the records of the baleen plates (Ruvd, 1940, 1945) are also caused by an increased addition of material from the epithelium of the gum to the cortex.

The increase in thickness of the whole baleen plate is, however, exaggerated by wear to which the free baleen plate is subject. During the growth of the animal the thickness of the baleen plate increases (vAN UTRECHT-Cock, 1965). The wedged form of the "root" of the baleen plate and its components, the corium wall and the epithelium that covers the corium wall, gives the impression that increment in thickness of the baleen plate is possible even in physically mature animals. This is confirmed by the fact that the horny tubes converge to an imaginary point, in the direction of the free part of the baleen plate. From transversal sections at various distances from the tip of the baleen plate it appears that the diameters of the tubes and the thickness of their walls increases.

Changes in the thickness of the superficial layers of the cortex of the baleen plate are instantaneous as a result of a sudden change in the physiological balance in the animals. In a record the peaks resulting from such changes give a better clue in the division into "growth periods" (see vaN UTRECHT-Cock, 1965). Moreover, they can give a better insight in the sexual cycle. For instance, when a certain peak in a record is the result of the stimulation of the epithelium by hormones produced during an ovulation which is followed by pregnancy there are always more data such as the corpus luteum in the ovaries, the length of the foetus or the condition of the mammary glands during lactation. From the length of the foetus conclusions can be drawn concerning the moment when this pregnancy started. This can be of importance particularly in female animals which have just reached sexual maturity and have ovulated only one or two times. The record of the baleen plate of such an animal offers a good basis for the comparison of certain peaks resulting from ovulations, with comparable peaks in the records of baleen plates of older female animals.

It is obvious that changes in the physiological balance, not only ovulations but all other kind of varia- 
tions in the life cycle of the Whales, which are of comparatively short duration, cause characteristic traces in the superimposed system of peaks in the record of the baleen plate.

\section{Summary}

1. In Whales variations in the thickness of the baleen plates are supposed to give an insight into certain cyclical processes in the life of the animal. To a certain extent, by means of these variations, it is possible to reach conclusions about the age of the animal and/or about its recent period of life.

In order to get a better insight in the significance of the variations in thickness of the baleen plate, researches are made in the histogenesis of the baleen plate of Fin Whales and Blue Whales, caught in the Antarctic waters. The variations in thickness are caused by variations in thickness of the cortex of the baleen plate.

2. The "root" of the baleen plate consists of the following parts: the corium wall, the epithelium that covers the corium wall, the cortex and the epithelium of the gum.

3. In the epithelium of the gum arched bands of varying width are visible. These bands run into the outer layer of the cortex. There is a correlation between the width of these bands and the height of the thickenings of the cortex, in which they end. These bands are not present in the epithelium that covers the corium wall. In both epithelia corium papillae are found. On the top of each papilla a row of spherical cells is formed. In the epithelium that covers the corium wall these rows of spherical cells all run into the cortex and there they cannot be distinguished from the surrounding cornified material. This is also correct for the very few rows of spherical cells originating from the corium papillae near the base of the corium wall. These rows run into the first band of flattened cells of the gum. They become flattened with the cells of the stratum spinosum of the gum in this band, forming the very first layer of the cortex. The other rows of spherical cells in the gum, even those immediately adjacent to the cortex, all run parallel to each other and to the outer surface of the cortex. They never run into the cortex. This shows clearly that the cell material of the gum forms the first and outer layer of the cortex of a baleen plate near the base of the corium wall. Cell material of the gum is not added to the cortex in any other place.

4. The cortex of a baleen plate is formed by two epithelia, the epithelium of the gum and the epithe- lium that covers the corium wall. Variations in the thickness of the cortex and consequently of the baleen plate, which are visible as peaks and hollows in the record, are only formed by variations in the addition of material by the epithelium of the gum.

5. One of the functions of the epithelium that covers the corium wall is that it serves as a layer by which the cortex slides from the corium wall. The long range and gradual increase in thickness of the baleen plate, and consequently also of the cortex, is mainly a result of the addition of material to the inner side of the cortex by this epithelium.

6. It is shown that the peaks and hollows are instantaneous formations, resulting from increased mitotic activity in the epithelium of the gum. These extra thickenings are only formed at a special point at the very first origin of the cortex. So the "growth periods" in which the records of baleen plates can be divided, by means of the "regular" occurrence of peaks and hollows, are conclusive in age determination.

7. The variations in thickness of the cortical layer of the baleen plate visible as peaks in the records, are probably caused by changes in the physiological balance of the Fin Whale. These changes are of comparatively short duration. They may e.g. be caused by the mitotic stimulating activity of hormones, produced by the ovaries during ovulation. Owing to such a stimulus more material is added to both sides of the cortex. This is visible as a thickening only on the outer surface because here all the extra material is added at one point, whereas to the inner side of the cortex material is added along the whole length.

8. The cells of the stratum spinosum in the "root" of the baleen plate maintain their mutual contact in the desmosomes. These structures are always visible in all microscopic sections of the various parts of this stratum.

9. The coarse tonofibrils run through the cells from the desmosomes in one part of the cell wall to the desmosomes in another, mostly opposite, part.

10. The tonofibrils are not present in all cells of the stratum spinosum of the gum and nowhere in the stratum spinosum of the epithelium between the corium wall and the cortex.

11. The presence of tonofibrils in the stratum spinosum of the gum of the Fin Whale and the Blue Whale is most probably caused by shrinkage of the cells, e.g. under the influence of the fixing fluid. The main direction of this shrinkage of the cells and the direction in which the tonofibrils run, is determined by forces that work on the cells in the epithelium, caused by mitotic activity. 


\section{Samenvatting}

De variaties, welke optreden in de dikte van de baleinen van Walvissen, kunnen een inzicht geven in bepaalde cyclische processen in het leven van deze dieren. Gebaseerd op deze dikte-variaties is het mogelijk de leeftijd van deze dieren te bepalen en inzicht te verkrijgen in hun recente levensgeschiedenis. Deze variaties in de dikte van de balein zijn alleen dan bruikbaar voor leeftijdsbepaling, wanneer zij op één bepaalde plaats en elk op één bepaald moment worden gevormd.

Om de betekenis en het ontstaan van deze variaties in dikte beter te kunnen interpreteren, is de histogenese van de baleinen van Gewone en Blauwe Vinvissen, gevangen in de Antarctische wateren, onderzocht.

De variaties in de dikte van de balein zijn een gevolg van de variaties in de dikte van de schorslaag van de balein.

Het onderzoek heeft zich geconcentreerd op de wortel van de balein, het deel dat zich in het tandvlees bevindt. De baleinwortel bestaat uit de volgende delen: de wigvormige coriumwal, aan beide zijden daarvan het epithelium dat deze wal bedekt, en daar buiten de schorslaag. Aan de schorslaag grenst het tandvlees, dat de ruimte tussen twee baleinwortels inneemt. Het tandvlees en het epithelium dat de coriumwal bedekt zijn epidermale weefsels. De schorslaag is het enige verhoornde deel dat aanwezig is in de baleinwortel.

De grens tussen de coriumwal en het epithelium is recht. Tussen twee naast elkaar gelegen coriumwallen is de grens tussen corium en het epithelium, dat het tandvlees vormt, boogvormig.

In het tandvlees zijn boogvormige banden aanwezig, die in breedte verschillen. Deze banden gaan over in de buitenste laag van de schorslaag. Er bestaat een correlatie tussen de breedte van deze banden en de hoogte van de verdikkingen van de schorslaag, waarin zij overgaan. Dergelijke banden zijn niet aanwezig in het epithelium dat de coriumwal bedekt.

In beide epithelia zijn coriumpapillen aanwezig. Op de top van iedere papil wordt een rij spherische cellen gevormd. In het epithelium dat de coriumwal bedekt, gaan deze reeksen cellen over in de schorslaag. $\mathrm{Zij}$ worden hier onherkenbaar van het omringende verhoornde weefsel. Dit geldt ook voor enkele reeksen spherische cellen, welke ontstaan op coriumpapillen in het tandvlees, gelegen bij de basis van de coriumwal. Deze reeksen eindigen in de eerste band van afgeplatte cellen in het tandvlees. Zij worden, evenals de cellen van het stratum spinosum van het tandvlees, afgeplat en vormen, samen met de cel- len van dit stratum, de eerste laag van de schorslaag, welke aanwezig is in de baleinwortel.

De overige reeksen spherische cellen in het tandvlees, zelfs die reeksen welke aan de schorslaag grenzen, lopen allen parallel ten opzichte van elkaar en ook ten opzichte van de schorslaag. Zij gaan niet over in de schorslaag.

In het tandvlees reiken de coriumpapillen voorbij de eerste zône van afgeplatte cellen van het stratum spinosum. Voorbij deze zône worden dus ook de spherische cellen gevormd.

Uit het feit dat deze cellen door de gehele diepte van het stratum spinosum van het tandvlees hun vorm behouden, en uit het feit dat de reeksen evenwijdig aan elkaar blijven lopen en niet opgenomen worden in de schorslaag, kan worden geconcludeerd dat afplatting van de cellen in het tandvlees alleen optreedt in deze eerste zône. Hieruit volgt dat cellen van het tandvlees de eerste en buitenste laag van de schorslaag vormen, nabij de basis van de coriumwal. Van het tandvlees uit worden verder geen cellen aan de schorslaag toegevoegd. Tegen deze buitenlaag van de schorslaag wordt door het epithelium dat de coriumwal bedekt, verhoornd materiaal afgezet. De schorslaag van de balein wordt dus gevormd door twee epithelia, door het epithelium van het tandvlees en het epithelium dat de coriumwal bedekt. Variaties in de dikte van de schorslaag en dus van de balein, welke als pieken en dalen in de baleindiktecurve zichtbaar zijn, kunnen uitsluitend ontstaan door variaties in de hoeveelheid materiaal, welke de buitenlaag van de schorslaag van de balein vormt.

Het epithelium dat de coriumwal bedekt, maakt het mogelijk dat de schorslaag van de coriumwal glijdt. De geleidelijke en continue toename van de dikte van de balein en ook van de schorslaag wordt veroorzaakt door de afzetting van materiaal van dit epithelium uit tegen de binnenzijde van de schorslaag.

Aangetoond is dat de pieken en dalen momentane afzettingen zijn als resultaat van verhoogde delingsactiviteit in het stratum basale en stratum spinosum van het tandvlees. De verdikkingen van de schorslaag worden alleen gevormd op één plaats, n.l. daar waar de eerste laag van de schorslaag onstaat. Dit betekent dat de pieken en dalen in de baleindiktecurven bruikbaar zijn voor een indeling van deze.curven in groeiperioden.

De variaties in de dikte van de schorslaag van de balein worden waarschijnlijk veroorzaakt door verschuivingen in het physiologisch evenwicht van de Walvis. Deze verschuivingen kunnen b.v. worden veroorzaakt door ovulatie, begin van de trek, etc. Het is bekend dat bij zoogdieren ovulaties begeleid worden 
door een verhoogde productie van oestrogene hormonen, waarvan is aangetoond dat deze de delingsactiviteit stimuleren. Aangenomen mag worden dat bij Walvissen tengevolge van een dergelijke verhoogde delingsactiviteit meer materiaal wordt toegevoegd aan beide zijden van de schorslaag. Dit kan alleen op het oppervlak van de balein zichtbaar worden als een verdikking, daar alle materiaal hier op één punt wordt afgezet terwijl tegen de binnenzijde van de schorslaag dit over de gehele lengte van deze laag, waar deze grenst aan het epithelium, plaats vindt.

De cellen van het stratum spinosum van de epithelia van de baleinwortel behouden hun onderling contact door middel van desmosomen. Deze structuren zijn altijd zichtbaar in de celwanden in de verschillende delen van dit stratum. Tonofibrillen zijn niet in alle cellen van het stratum spinosum van het tandvlees zichtbaar, en in het geheel niet in het stratum spinosum van het epithelium dat de coriumwal bedekt. Wanneer tonofibrillen aanwezig zijn, gaan zij van de desmosomen in het ene deel van de celwand door de cel naar de desmosomen in het tegenover gelegen deel van de celwand.

De anwezigheid van tonofibrillen in het stratum spinosum van het tandvlees wordt zeer waarschijnlijk veroorzaakt door krimpen van de cellen, b.v. ten gevolge van de werking van fixatie vloeistoffen. De richting, waarin dit krimpen van de cellen plaats vindt, en de richting, waarin de tonofibrillen verlopen, wordt bepaald door krachten welke op de cellen van het epithelium werken, veroorzaakt door delingsactiviteit.

\section{Acknowledgements}

The research concerning age determination on $\mathrm{Ba}$ leen Whales is made as a part of the research program of the former Whales Research Group T.N.O., under the management of the Organisation Commis- sion for Fisheries of the Central Organisation T.N.O.

Grateful acknowledgement is made to this Organisation and to the "Curatorium" of the Research Group, in particular to its President Prof. Dr. E. J. Slijper, Director of the Zoological Laboratory of the University of Amsterdam, for his constant interest in the subject, and to the members of the "Curatorium", Dr. B. Havinga and Prof. Dr. P. Korringa.

Grateful acknowledgements are also made to $\mathrm{Mr}$. H. Drost, former Inspector of the 1st District (Sea fisheries) of the Department of Agriculture and Fisheries and to Ir. J. G. de Wit, Inspector of the 1st District.

The author is very much indebted to Mr. W. H. E. van Dijk, chief Whaling Inspector of the Department of Agriculture and Fisheries, for his constant interest in the subject and his enthusiasm and great care in sampling all material and collecting data all needed during a considerable number of years, by which this work was made possible, as well as for his fine companionship during the season 1962-1963 on board the former f.f. "Willem Barendsz".

Grateful acknowledgements are made to Prof. Dr. J. T. Ruud, Director of the Institutt for Marin Biologi of the University of Oslo, Norway, and to $\AA$. Jonsgard and A. Hylen for the profound discussions about this subject.

To the board of Directors of the Dutch Whaling Comp. Ltd., Amsterdam, and in particular to Ir. L. de Waal, the author is very much indebted for providing a part of the finances of the Whales Research Group T.N.O. and the facilities on board their factory ship.

Grateful acknowledgements are also made to Captain I. J. Klein and Captain H. Jansma, former masters of the m.s. "Willem Barendsz" and the officers and crew of this ship, in particular to Mr. P. Bakker, J. Holwerda, J. Kiel and A. Kiel for their advices and assistance in sampling the great mass of material.

\section{REFERENCES}

ANONYMous, 1952: Observations on whales from ships. Nat. Inst. Oceanography, London.

Arseniev, V. A., S. G. Brown, R. G. Chittleborough and H. OMURA, 1962: Report on whale marking. Report of the Scientific Commission of the International Whaling Commission. Mimeographed.

BAKER, A. DE C., 1954: The circumpolar continuity of Antarctic plankton species. Discovery Reports, Vol. 27, p. 201.

- 1964: 1962-1963, Ann. Rep. Nat. Oceanograph. Council, p. 21.

BEAN, W. B., 1963: Nail growth. A twenty-year study. Arch. Intern. Med., Vol. 111, p. 476.
- 1963: A discourse on nail growth and unusual fingernails. Trans. Amer. Clin. and Climat. Ass., Vol. 74, p. 152.

Biggers, J. D. and P. J. Claringbold, 1955: Mitotic activity in the vaginal epithelium of the mouse following local oestrogenic stimulation. Journ. Anat., Vol. 139, p. 124.

Boden, B. P., 1955: Euphausiacea of the Benguela Current. Discovery Reports, Vol. 27, p. 337.

Brown, S. G., 1954: Dispersal in Blue and Fin Whales. Discovery Reports, Vol. 26, p. 355.

- 1956: Whale marks recently recovered. Norsk Hvalfangst-Tidende, nn. 12 , p. 661 . 
- 1957: Whales observed in the Indian Ocean. The Marine Observer, Vol. 27, no. 177, p. 157.

- 1957: Whale marks recovered during the Antarctic whaling season 1956/1957. Norsk Hvalfangst-Tidende, no. 10 , p. 555 .

- 1958: Whales observed in the Atlantic Ocean. The Marine Observer, Vol. 28, no. 181, p. 142.

- 1958: Whales observed in the Atlantic Ocean. The Marine Observer, Vol. 28, no. 182, p. 209.

- 1958: Whale marks recovered during the Antarctic whaling season 1957/1958. Norsk Hvalfangst-Tidende, no. 10 , p. 503 .

- 1959: Whale marks recovered in the Antarctic seasons 1955/56, 1958/59 and in South Africa 1958 and 1959. Norsk Hvalfangst-Tidende, no. 12, p. 609.

- 1960: Swordfish and Whales. Norsk Hvalfangst-Tidende, no. 8 , p. 345 .

- 1960: Whale marks recovered in the Antarctic whaling season 1959/1960. Norsk Hvalfangst-Tidende, no. 10, p. 457.

- 1961: Whale marks recovered in the Antarctic whaling season 1960/1961. Norsk Hvalfangst-Tidende, no. 10, p. 407.

- 1962: Whale marks recovered during Antarctic seasons $1960 / 61,1961 / 62$ and in South Africa 1962. Norsk Hvalfangst-Tidende, no. 11, p. 429.

Bullough, H. F., 1943: Cyclical changes in the skin of the mouse during the oestrus cycle. Journ. Endocrinol., Vol. 3, p. 280.

- 1947: Epidermal thickness following oestrone injections in the mouse. Nature, Vol. 159 , no. 4029 , p. 101.

Bullough, W. S., 1946: Mitotic activity in the adult female mouse, Mus musculus L., a study of its relation to the oestrus cycle in normal and abnormal conditions. Phil. Trans. Roy. Soc. London, Sect. B, Vol. 231, p. 453.

- 1949: The effect of a restricted diet on mitotic activity in the mouse. Brit. Journ. Cancer, Vol. 3, p. 275.

- 1962: The control of mitotic activity in adult mammalian tissues. Biol. Rev., Vol. 37, p. 307.

Burgos, M. H. and G. B. Wislocky, 1956: Cyclical changes in the guinea pig's uterus, cervix and vagina, and sexual skin investigated with histological and histochemical means. Endocrinology, Vol. 59, p. 93.

Carleton, A., 1934: A rhythmical periodicity in the mitotic division of animal cells. Journ. Anat., Vol. 68, p. 251.

CARTER, S. B., 1953: The influence of oestrone on the division of cells. Journ. Endocrinol., Vol. 9, p. 19.

Carruthers, J. N., S. S. Gogate, J. R. Naidu and T. LAEVASTU, 1959: Shorewards upslope of the layer of minimum oxygen off Bombay: Its influence on marine biology, especially fisheries. Nature, Vol. 138, p. 1084.

Chambers, R. and G. S. RÉNYI, 1925: The structure of the cells in tissues as revealed by microdissection. I. The physical relationship of the cells in epithelia. Amer. Journ. Anat., Vol. 35, p. 385.

Chapman, G. B. and A. B. Dawson, 1961: Fine structure of the larval Anuran epidermis with special reference to the figures of Ebert. Journ. Biophys. and Biochem. Cytol., Vol. 10, no. 3, p. 425.

Charles, A. and F. G. Smiddx, 1957: The tonofibrils in human epidermis. Journ. Invest. Dermatol., Vol. 29, no. 5. p. 327.
Chittleborough, R. G., 1953: Aerial observations on the Humpback Whale, Megaptera nodosa (Bonnaterre) with notes on other species. Aust. J. Mar. Fresh. Res., Vol. 4, no. 2, p. 219.

- 1954: Studies on the ovaries of the Humpback Whale, Megaptera nodosa (Bonnaterre), on the western Australian coast. Aus. J. Mar. Fresh. Res., Vol. 5, no. 1, p. 35.

- 1955: Aspects of reproduction in the male Humpback Whale, Megaptera nodosa (Bonnaterre). Aust. J. Mar. Fresh. Res., Vol. 6, no. 1, p. 1.

- 1958: The breeding cycle of the female Humpback Whale, Megaptera nodosa (Bonnaterre). Aust. J. Mar. Fresh. Res., Vol. 9, no. 1, p. 1.

- 1958: An analysis of recent catches of Humpback Whales from the stocks in groups IV and V. Norsk Hvalfangst-Tidende, no. 3, p. 109.

- 1959: Determination of age in the Humpback Whale, Megaptera nodosa (Bonnaterre). Aust. J. Mar. Fresh. Res., Vol. 10, no. 2, p. 125.

- 1959: Australian marking of Humpback Whales. Norsk Hvalfangst-Tidende, Vol. 48, no. 2, p. 47.

- 1960: Marked Humpback Whale of known age. Nature, Vol. 187, p. 164.

Clarke, R., 1957: Migrations of marine mammals. Norsk Hvalfangst-Tidende, no. 11 , p. 609.

Cooper, Z. K. and A. SCHIFF, 1938: Mitotic rhythm in human epidermis. Proc. Soc. Exp. Biol. and Med., Vol. 39 , p. 323.

CoOPER, Z. K. and H. C. Frankin, 1940: Mitotic rhythm in the epidermis of the mouse. Anat. Rec., Vol. 78, p. 1.

Couturier, A. J., 1938: Le Chamois. B. Arthaud. Grenoble.

Crary, D. D. and P. B. SAwIN, 1953: Some factors influencing the growth potential of the skin in the domestic rabbit. Journ. Exp. Zool., Vol. 124, no. 1, p. 31 .

Currie, R., 1953: Upwelling in the Benguela Current. Nature, Vol. 171, p. 497.

DawBIN, W. H., 1956: The migration of Humpback Whales, which pass the New Zealand coast. Trans. Roy. Soc. New Zealand, Vol. 84, part 1, p. 147.

- 1960: The composition of the New Zealand whale catch in 1959. Norsk Hvalfangst-Tidende, no. 9, p. 401.

Deacon, G. E. R., 1959: The Antarctic Ocean. Science Progress, Vol. 47, p. 647.

Deane, H. M., R. W. Davis, G. P. Epling and R. Jensen, 1955: The anatomy of the integument of the ovine foot. Amer. Journ. Vet. Res., Vol. 16, no. 59, p. 197.

Dick, J. C., 1947: Observations on the elastic tissue of the skin with a note on the reticular layer at the function of dermis and epidermis. Journ. Anat., Vol. 81, p. 202.

Dissel-Scherf, M. C. and W. Vervoort, 1954: Development of the teeth in fetal Balaenoptera physalus (L), (Cetacea, Mysticeti). I. Proc. Kon. Ned. Akad. Wet., Series C, Vol. 57, no. 2, p. 196.

Drion, E. F. and E. J. SLIJPER, 1955: Some remarks on the stock of Fin Whales in the Antarctic. Mimeographed.

Earland, C., P. R. Blakey and J. G. P. Stell, 1962: Molecular orientation of some keratins. Nature, Vol. 196 , p. 1287.

Ebling, F. J., 1953: Some effects of oestrogen on the 
epidermis. Proc. Soc. Endocrinol. (1952); Journ. Endocrinol., Vol. 9, p. 31.

- 1957: The action of testosterone and oestradiol on the sebaceous glands and epidermis of the rat. Journ. Embryol. Exptl. Morph., Vol. 5, no. 1, p. 74.

EMmens, C. W., 1942: The endocrine system and hairgrowth in the rat. Journ. Endocrinol., Vol. 3, no. 1, p. 64 .

ERNST, R. J., 1954: Die Bedeutung der Wandepidermis (Hyponychium) des Pferdenhufes für die Hornbildung. Acta Anat., Vol. 22, no. 1, p. 15.

Eschricht, D. F. og J. ReinhardT, 1861: Om Nordvhalen (Balaena mysticetus L). K. Danske Vidensk. Selskabs. Skrifter, 5 Raekke Naturvid. og Mathem. Afd. B V, p. 433 .

Eschricht, D. F. and J. ReInhaRdT, 1866: On the Greenland Right Whale (Balaena mysticetus) in Recent Memoirs on the Cetacea. Ray Soc., London, p. 68.

Fambach, R., 1898: Die Ringbildung an den Hörner der Cavicornier. Inaug. Diss., Univ. Basel.

FAWCETT, D. W., 1958: Structural specialisations of the cell surface in Frontiers in Cytology, (S. L. Palay, Editor), New Haven, Yale Univ. Press.

Fraser, A. S. and T. NAY, 1955: Growth of the mouse coat. IV. Comparison of naked and normal mice. Aust. Journ. Biol. Sci., Vol. 8, p. 420.

Frazer, J. F. D. and A. St. G. Huggett, 1958: The breeding season and length of pregnancy in four species of large Whales. XVth Intern. Congr. Zool., Sect. 3, Paper 39.

Fujino, K., 1960: Immunogenetic and marking approaches to identifying subpopulations of the North Pacific Whales. Sci. Rep. Wh. Res. Inst. Tokyo, no. 15, p. 85.

Fuschlberger, H., 1955: Das Gamsbuch. F. C. Mayer, München-Hamburg.

Gilchrist, M. L. and L. H. D. Buxton, 1938/1939: The relation of fingernail growth to the nutritional status. Journ. Anat., Vol. 73, p. 575.

HABERMEHL, K.-H., 1961: Die Altersbestimmung bei Haustieren, Pelztieren und beim jagdbaren Wild. Paul Parey, Berlin-Hamburg.

HART, T. J., 1935: On the diatoms of the skinfilm of Whales and their possible bearing on problems of whale movements. Discovery Reports, Vol. 10, p. 247.

- 1942: Phytoplankton periodicity in Antarctic surface waters. Discovery Reports, Vol. 21, p. 261.

- 1953: Plankton of the Benguela Current. Nature, Vol. 171, p. 631.

HAY, D. E., 1961: Fine structure of an unusual intracellular supporting network in the Leydig cells of Amblystoma epidermis. Journ. Biophys. Biochem. Cytol., Vol. 10 , no. 3 , p. 457.

HIRAKI, Y., 1963: Electron microscopic observations on the epidermis of Pseudorca crassidens (in Japanese). Yamaguchi Med. Ass. 12/3, p. 186; Excerpta Medica, Vol. 19, no. 1, Section 1, 1965.

HoLM, J. L. and A. JoNSGÅRD, 1959: Occurrence of the Sperm Whale in the Antarctic and the possible influence of the moon. Norsk Hvalfangst-Tidende, no. 4, p. 161 .

Hooker, C. W. and C. A. Pfeiffer, 1943: Effects of sex hormones upon body growth, skin, hair and sebaceous glands in the rat. Endocrinol., Vol. 32 , p. 69.

HorstmanN, E., 1955: Bau und Struktur des mensch- lichen Nagels. Zeitschr. für Zellforsch., Bd. 191, p. 532. - 1957: Die Haut. In Möllendorf: Handbuch der Mikroskopischen Anatomie des Menschen. Springer Verlag, Berlin-Göttingen-Heidelberg.

HorstmanN, E. und A. KNOOP, 1958: Electronenmikroskopische Studien an der Epidermis. I. Rattenpfote. Zeitschr. für Zellforsch. und Mikroskop. Anat., Vol. 47, p. 348.

HUNTER, J., 1787: Observations on the structure and economy of whales. Phil. Trans. Roy. Soc. London, Vol. 77, p. 371.

ICHIHARA, T., 1959: Formation mechanism of earplug in baleen whales, in relation to glove-finger. Sci. Rep. Wh. Res. Inst. Tokyo, no. 14, p. 107.

JoHN, D. D., 1936: The southern species of the genus Euphausia. Discovery Reports, Vol. 14, p. 193.

JoNSGÅRD, A., 1951: Studies on the Little Piked Whale (Balaenoptera acuto-rostrata, Lacépède). Norsk Hvalfangst-Tidende, no. 5, p. 209.

- 1952: On the growth of the Fin Whale (Balaenoptera physalus) in different waters. Norsk Hvalfangst-Tidende, no. 2 , p. 57.

- 1954: Om småhvalfangsten på Norske kysten og om vågehvalen. Fauna, no. 2, p. 49.

- 1954: Om småhvalfangsten på Norske kysten og om vågehvalen. Fauna, no. 3 , p. 123.

- 1954: Om småhvalfangsten på Norske kysten og om vågehvalen. Fauna, no. 4, p. 162.

- 1955: Development of the modern Norwegian small whale industry. Norsk Hvalfangst-Tidende, no. 12, p. 697.

- 1959: New find of sword from swordfish (Xiphias gladius) in Blue Whale (Balaenoptera musculus) in Antarctic. Norsk Hvalfangst-Tidende, no. 7, p. 352.

KARLSEN, K., 1962: Development of toothgerms and adjacent structures in the whalebone whale (Balaenoptera physalus (L)) with a contribution to the theories of the mammalian dentition. Hvalrådets Skrifter, no. 45 , p. 1.

Kato, K., 1962: The influence of dietary fats, fatty acids and sexual hormones upon the skin of the rats. Jap. Journ. Dermatol., 73 (3), p. 241.

KüKENTHAL, W., 1893: Vergleichend-anatomische und entwicklungsgeschichtliche Untersuchungen. Denkschr. Med. Naturw. Ges. Jena, Bd. 3, p. 422.

LaUrie, A. H., 1937: The age of female Blue Whales and the effect of whaling on the stock. Discovery Reports, Vol. 15, p. 223.

LAws, R. M., 1956: Determination of age of the larger whales (Mysticeti). Polar Rec., Vol. 8, p. 175.

- 1956: Growth and sexual maturity in aquatic mammals. Nature, Vol. 178, p. 193.

- 1958: Recent investigations on Fin Whale ovaries. Norsk Hvalfangst-Tidende, no. 5, p. 225.

- 1958: Age determination of whales by means of corpora albicantia. XVth Intern. Congr. Zool., Sect. 3, paper 36.

- 1958: Growth rates and ages of Crabeater Seals, Lobodon carcinophagus Jaquinot \& Pucheran. Proc. Zool. Soc. London, Vol. 130, part 2, p. 275.

- 1959: On the breeding season of southern Hemisphere Fin Whales, Balaenoptera physalus (Linn). Norsk Hvalfangst-Tidende, no. 7 , p. 329.

- 1959: The foetal growth rates of whales with special reference to the Fin Whale, Balaenoptera physalus, Linn. Discovery Reports, Vol. 29, p. 281. 
- 1960: Problems of whale conservation. Trans. 25th N. Amer. Wildlife Conf.

- 1961: Reproduction, growth and age of southern Fin Whales. Discovery Reports, no. 31, p. 327.

LAws, R. M. and P. E. Purves, 1956: The earplug of the Mysticeti as an indication of age with special reference to the North Atlantic Fin Whale (Balaenoptera physalus Linn). Norsk Hvalfangst-Tidende, no. 8, p. 413.

Le Gros Clark, W. L. and L. H. D. Buxton, 1938: Studies in nailgrowth. Brit. Journ. Dermatol. Syph., Vol. 50, p. 221.

Lewis, S. R., C. M. Pomerat and D. Ezell, 1949: Human epidermis cells observed in tissue culture with phasecontrast microscopy. Anat. Rec., Vol. 104, p. 487.

LOEB, L. and F. L. HAVEN, 1929: The relation between functional status of the sex organs in the female guinea pig and cell proliferations in the epidermis. Anat. Rec., Vol. 43 , p. 1 .

Mackintosh, N. A., 1934: Distribution of the macroplankton in the Antarctic sector of the Atlantic. Discovery Reports, Vol. 9, p. 65.

- 1942: The southern stocks of whalebone whales. Discovery Reports, Vol. 22, p. 197.

- 1952: Observations on whales from ships. The Marine Observer, Vol. 22, no. 156, p. 87.

- 1955: Whale marks recently recovered. Norsk Hvalfangst-Tidende, no. 1, p. 24.

- 1955: Whale marks recently recovered. Norsk Hvalfangst-Tidende, no. 12 , p. 718 .

- 1960: The pattern of distribution of the Antarctic fauna. Proc. Roy. Soc. London, Series B, Vol. 152, p. 624 .

Mackintosh, N. A. and J. F. G. Wheeler, 1929: Southern Blue and Fin Whales. Discovery Reports, Vol. 1, p. 257.

MCCreight, CH. E. and W. ANDREW, 1956: Diversity of cell types in the epidermis of the mouse under normal conditions and following topical application of estrogen. Anat. Rec., Vol. 125, p. 761.

MARR, J. W. S., 1956: Euphausia superba and Antarctic surface currents. (An advance note on the distribution of the whale food). Norsk Hvalfangst-Tidende, no. 3, p. 127.

- 1957: Further comments on the occurrence of Euphausia superba in a Humpback Whale caught off Southern Queensland. Norsk Hvalfangst-Tidende, no. 4, p. 181.

MartinotTI, L., 1921: Ricerche sulla fine struttura dell epidermide umana normale in rapporto alla sua funzione eleido cheratinica. Arch. Zellforsch., Vol. 15, p. 377.

Medawar, P. B., 1953: The microanatomy of the mammalian epidermis. Quart. Journ. Micr. Sci., Vol. 94, part 4 , sect. 3 , no. 28 , p. 481 .

Mizue, K. and H. Jimbo, 1950: Statistic study of foetuses of whales. Sci. Rep. Wh. Res. Inst. Tokyo, no. 3, p. 119.

Montagna, W., 1956: The structure and function of the skin. Acad. Press Inc. Publ., New York.

Montagna, W. and R. J. Harrison, 1957: Specialization in the skin of the seal (Phoca vitulina). Amer. Journ. Anat., Vol. 100 , no. 1 , p. 81 .

Montagna, W., P. Kenyon and J. B. Hamilton, 1949: Mitotic activity in the epidermis of the rabbit stimulated with local application of testosterone propionate. Journ. Exptl. Zool., Vol. 110, p. 379.
Moore, H. B., 1958: Marine ecology. Wiley \& Sons Inc., New York.

MörIKE, K. D., 1954: Das Verhalten des Hyponychiums beim normalen Nagelwachstum. Verhandl. Anat. Ges. '52 Versammlung in Münster, p. 289.

- 1955: Ein bindegewebiges Hafter um das Matrixepithel des Nagels und der Krallen. Zeitschr. Anat. Entw. Gesch., Bd. 119, Heft 1, p. 23.

Moulin, F. DE, 1923: Der Verhornungsprozess der Haut und der Hautderivative. Anat. Anz.. 56, p. 461.

NaAktgeboren, C., E. J. Slijper and W. L. van Utrecht, 1960: Researches on the period of conception, duration of gestation and growth of the foetus in the Fin Whale, based on data from the International Whaling Statistics. Norsk Hvalfangst-Tidende, no. 3, p. 113.

NAY, T. and A. S. Fraser, 1955: Growth of the mouse coat. V. Effects of pregnancy and lactation. Austr. Journ. Biol. Sci., Vol. 8, p. 428.

Nemoto, T., 1955: White scars on whales (I) Lamprey marks. Sci. Rep. Wh. Res. Inst. Tokyo, no. 10, p. 69.

- 1959: Food of baleen whales with reference to whale movements. Sci. Rep. Wh. Res. Inst. Tokyo, no. 14, p. 149.

Nickel, R., 1938: Ueber den Bau der Hufröhrchen und seine Bedeutung für den Mechanismus des Pferdenhufes. Dtsch. Tierärzl. Wschr., 46, p. 449.

NishiWAKI, M., 1950: Age characteristics in baleen plates. Sci. Rep. Wh. Res. Inst. Tokyo, no. 4, p. 162.

-1951: On the periodic mark on the baleen plates as a sign of annual growth. Sci. Rep. Wh. Res. Inst. Tokyo, no. 6 , p. 133.

- 1952: On the age determination of Mystacoceti, chiefly Blue and Fin Whales. Sci. Rep. Wh. Res. Inst. Tokyo, no. 7, p. 87 .

- 1957: Age characteristics of earplugs of whales. Sci. Rep. Wh. Res. Inst. Tokyo, no. 12, p. 23.

- 1959: Humpback Whales in Ryukyuan waters. Sci. Rep. Wh. Res. Inst. Tokyo, no. 14, p. 49.

- 1960: Ryukyuan Humpback whaling in 1960. Sci. Rep. Wh. Res. Inst. Tokyo, no. 15, p. 1.

Nishiwaki, M., T. Ichihara and S. Ohsumi, 1958: Age studies of Fin Whales based on earplug. Sci. Rep. Wh. Res. Inst. Tokyo, no. 13, p. 155.

OdLaND, G. F., 1950: The morphology of the attachment between the dermis and epidermis. Anat. Rec., Vol. 108 , p. 399.

- 1958: The fine structure of the interrelationship of cells in the human epidermis. Journ. Biophys. Biochem. Cytol., Vol. 4, p. 529.

Orsumi, S., 1960: Relative growth of the Fin Whale, Balaenoptera physalus (Linn.). Sci. Rep. Wh. Res. Inst. Tokyo, no. 15, p. 17.

OTTESTAD, P., 1938: Variations in the size distributions of southern Blue and Fin Whales (A preliminary report on:). Hvalrådets Skrifter, no. 18, p. 49.

PARRY, D. A., 1949: The structure of whale blubber and a discussion of its thermal properties. Quart. Journ. Micr. Sci., Vol. 90, part 1, p. 13.

Patzelt, W., 1954: Ueber Tonofibrillen, Keratohyalin, Glycogen und Verhornung der Epidermis. Acta Anat., Vol. 21 , no. 4 , p. 349.

Pautard, F. G. E., 1963: Mineralization of keratin and its comparison with the enamel matrix. Nature, Vol. 199 , p. 531. 
Pease, D. C., 1951: Electron microscopy of human skin. Amer. Journ. Anat., Vol. 89, p. 469.

PIKE, G. C., 1951: Lamprey marks on whales. Journ. Fish. Res. Canada, 8 (4).

- 1953: Progress report of the Pacific coast stations of the Fisheries Research Board of Canada, no. 97, p. 3.

Pouchet, M. G. and H. Beauregard, 1885: Note sur le développement des fanons. Compt. Rend. Soc. Biol., Tome 2, Ser. 8, p. 477.

PURVES, P. E., 1955: The wax plug in the external auditory meatus of the Mysticeti. Discovery Reports, Vol. 27, p. 293.

- 1958: The use of the earplug in age determination in whales. XVth Intern. Congr. Zool., Sect. 3, paper 35.

Purves, P. E. and M. D. MountFord, 1959: Earplug laminations in relation to the age composition of a population of Fin Whales (Balaenoptera physalus). Bull. Brit. Mus. (Nat. Hist.), Vol. 5, no. 6, p. 125.

RAVIN, 1836: Observations anatomiques sur les fanons, sur leur mode d'insertion entre et avec la membrane palatine. Ann. Sci. Nat., Ser. 2, Tome 5, Zool., p. 266.

Romanini, M. G., 1954: A histochemical characteristic of skin desmosomes in Vertebrates. Arch. Ital. Anat. Embriol., 59 (2), p. 201.

RomeIs, B., 1948: Taschenbuch der mikroskopischen Technik, 15. Aufl., München.

Rosenthal, 1928: Ueber die Barten des Schnabel-Walfisches. Abhandl. Kgl. Akad. Wissensch., Berlin, p. 127.

Rothman, S., 1955: Physiology and biochemistry of the skin. Univ. Chicago Press (Pinkus, H., p. 584).

RuUd, J. T., 1940: The surface structure of the baleen plate as a possible clue to age in whales. Hvalrådets Skrifter, no. 23, p. 1.

- 1945: Further studies on the structure of the baleen plates and their application to age determination. Hvalrådets Skrifter, no. 29 , p. 1 .

- 1958: The use of baleen plates in age determination of whales. XVth Intern. Congr. Zool., Sect. 3, paper 37.

RuUd, J. T., A. Jonsgård and P. OtTestad, 1950: Age studies on Blue Whales. Hvalrådets Skrifter, no. 33, p. 1.

SALECKER, J., 1943: Die fibrillären Architektur der menschlichen Epidermis. Morph. Jahrb., Bd. 88, p. 225.

SANt, G., 1954/55: Die Nukleinsäuren im Scheidenepithel der Ratte während der Brunstzyklus und unter verschiedenen experimentellen Umstände. Anat. Anz., Bd. 101, p. 167.

Schmidt, W. J. und H. Sprankel, 1954: Bildet sich im Stratum corneum des Rinderhornes Röhrchenstruktur aus? Zeitschr. Morphol. Oekol. Thiere, Bd. 42, p. 449.

Scholander, P. F., 1958: Counter current exchange. A principle in biology. Hvalrådets Skrifter, no. 44, p. 1 .

Scholander, P. F. and J. KroG, 1957: Countercurrent heat exchange and vascular bundles in Sloth. Journ. Appl. Physiol., Vol. 10, p. 405.

Scholander, P. F. and W. E. Schevill, 1955: Countercurrent vascular heat exchange in the fins of whales. Journ. Appl. Physiol., Vol. 8, no. 3, p. 279.

SCORESBY, W., 1820: An account of the Arctic Regions, Vol. 1, Edinburg.
SELBY, C. C., 1957: An electron microscope study of thin sections of human skin. II. Superficial cell layers of footpad epidermis. Journ. Invest. Dermatol., Vol. 28, no. 1, p. 131 .

SLIJPER, E. J., 1948: On the thickness of the layer of blubber in Antarctic Blue and Fin Whales, I-III. Proc. Kon. Ned. Akad. Wet., Vol. 51, pp. 1033, 1114, 1310.

- 1954: On the importance of measuring the layers of blubber in whales. Norsk Hvalfangst-Tidende, no. 9, p. 510.

SLIJPER, E. J. and W. L. VAN UTRECHT, 1959: Observing whales. Norsk Hvalfangst-Tidende, no. 3, p. 101.

SliJper, E. J., W. L. VAN UTRECht and C. NAAkTGEboren, 1964: Remarks on the distribution and migration of whales, based on observations from Netherlands ships. Bijdr. Dierk., Afl. 34, p. 4.

SokoLow, W., 1958: Adaptations of the skin in marine mammal fauna of the U.S.S.R. to some conditions of life in water. XVth Intern. Congr. Zool., Sect. 3, paper 20.

SymoNs, H. W., 1956: Some observations on the ear of Blue and Fin Whales. Norsk Hvalfangst-Tidende, no. 1, p. 37.

TomiLiN, A. G., 1945: The age of whales as determined from their baleen apparatus (in Russian). Compt. Rend. (Doklady) Acad. Sci. U.S.S.R., XLIX, no. 6.

TullBerg, T., 1883: Bau und Entwicklung der Barten bei Balaenoptera sibbaldii. Nova Acta Soc. Upsaliensis, seriei tertiae, Vol. XI, p. 1.

UTRECHT, W. L. VAN, 1958: Temperaturregulierende Gefässystemen in der Haut und andere epidermale Strukturen bei Cetacea. Zool. Anz., Bd. 161, Heft 3/4, p. 77.

- 1959: Wounds and scars in the skin of the Common Porpoise, Phocaena phocaena (L), Mammalia, Tome XIII, no. 1, p. 100.

Utrecht, W. L. van and C. N. Cock, 1955: Provisional report concerning age determination in Fin Whales by means of baleen plates. Report Scientific Commission International Whaling Commission. Mimeographed.

UTRECHT-Cock, C. N. van, 1965: Age determination and reproduction of female Fin Whales. Bijdr. Dierk., 35, p. 39 .

WALFORD, L. A., 1958: Living resources of the sea. The Roland Press Comp., New York.

WeIss, P., 1958: Cell contact. Intern. Rev. Cytol., Acad. Press Inc., New York, p. 391.

WeISS, P. and W. FERRIS, 1954: Electronmicrograms of larval amphibian epidermis. Exptl. Cell Res., Vol. 6, p. 546.

WILKENS, H., 1955: Zum mikroarchitektonischen Aufbau der Klauenepidermis. Dtsch. Tierärzl. Wschr., Jahrg. 62 , p. 437.

Yablokov, A. V. and T. V. ANDReyeVA, 1965: Age determination in baleen whales (Mystacoceti). Nature, Vol. 205 , p. 412.

Ziegler, H., 1951: Ueber die Bildung des Hufhorns. Schw. Arch. Tierheilk., Bd. XCIII, Heft 5, p. 295.

ZwillenBerg, L. O., 1959: Beiträge zur Kenntnis des geschichteten Pflasterepithels. Acta Anat., Suppl. 35, 1 ad., Vol. 37. 